Florida International University FIU Digital Commons

$11-5-2012$

\title{
Three Essays on a Longitudinal Analysis of Business Start-ups using the Kauffman Firm Survey
}

Indu Khurana

Florida International University, ikhur002@fiu.edu

DOI: $10.25148 /$ etd.FI12120405

Follow this and additional works at: https://digitalcommons.fiu.edu/etd

\section{Recommended Citation}

Khurana, Indu, "Three Essays on a Longitudinal Analysis of Business Start-ups using the Kauffman Firm Survey" (2012). FIU Electronic Theses and Dissertations. 765.

https://digitalcommons.fiu.edu/etd/765 


\title{
FLORIDA INTERNATIONAL UNIVERSITY
}

Miami, Florida

\section{THREE ESSAYS ON A LONGITUDINAL ANALYSIS OF BUSINESS START-UPS USING THE KAUFFMAN FIRM SURVEY}

\author{
A dissertation submitted in partial fulfillment of the \\ requirements for the degree of \\ DOCTOR OF PHILOSOPHY \\ in \\ ECONOMICS \\ by \\ Indu Khurana
}

2012 
To: $\quad$ Dean Kenneth G. Furton

College of Arts and Sciences

This dissertation, written by Indu Khurana, and entitled Three Essays on a Longitudinal Analysis of Business Start-ups using the Kauffman Firm Survey, having been approved in respect to style and intellectual content, is referred to you for judgment.

We have read this dissertation and recommend that it be approved.

Cem Karayalcin

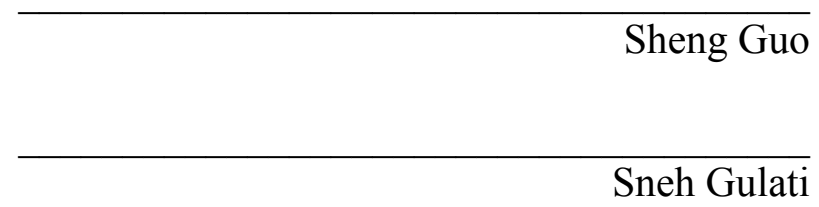

Peter Thompson, Major Professor

Date of Defense: November 5, 2012

The dissertation of Indu Khurana is approved.

\begin{tabular}{r} 
Dean Kenneth G. Furton \\
College of Arts and Sciences \\
\hline Dean Lakshmi N. Reddi \\
University Graduate School
\end{tabular}

Florida International University, 2012 


\section{DEDICATION}

This dissertation is dedicated to my family. Thank you for being there with me. 


\section{ACKNOWLEDGMENTS}

It is customary to thank one's advisor while writing the acknowledgement section in the dissertation, however, my gratitude towards Dr. Thompson goes beyond writing this rubric. His support, patience, encouragement, and honest criticism helped me in completing this dissertation. Without his motivation, this dissertation would not have been possible. My sincerest thanks to you, Dr. Thompson!!

I would also like to thank other members of my committee, Dr. Cem Karayalcin, Dr. Sheng Guo, and Dr. Sneh Gulati. Dr. Karayalcin has continuously supported me during this entire period, and has always been prompt in furnishing any kind of documentation support; not to mention his technological skills that he happily shares with the students. The empirical questions in my research were addressed to Dr. Guo. He has helped me in solving any problem related to STATA code, or interpreting any empirical model. Conversations about my research and hometown with Dr. Gulati were always a delight. I would also like to show my gratitude to the staff, and my friends at the Department of Economics for always being prompt in helping me whenever required.

My special thanks to my parents and sister for being there with me. I could not have asked for a more supportive family. A special note of thanks to Priyanka!! On this path of writing my dissertation, I tied the nuptial knot with Rupak. Thanks for being so understanding, and providing me the emotional strength when I needed it the most. I cannot thank you all enough!!

Last but not the least; I am also grateful to the Ewing Marion Kauffman Foundation for providing access to the confidential Kauffman Firm Survey data. 


\section{ABSTRACT OF THE DISSERTATION \\ THREE ESSAYS ON A LONGITUDINAL ANALYSIS OF BUSINESS START-UPS \\ USING THE KAUFFMAN FIRM SURVEY}

by

Indu Khurana

Florida International University, 2012

Miami, Florida

\section{Professor Peter Thompson, Major Professor}

This dissertation focused on the longitudinal analysis of business start-ups using three waves of data from the Kauffman Firm Survey.

The first essay used the data from years 2004-2008, and examined the simultaneous relationship between a firm's capital structure, human resource policies, and its impact on the level of innovation. The firm leverage was calculated as, debt divided by total financial resources. Index of employee well-being was determined by a set of nine dichotomous questions asked in the survey. A negative binomial fixed effects model was used to analyze the effect of employee well-being and leverage on the count data of patents and copyrights, which were used as a proxy for innovation. The paper demonstrated that employee well-being positively affects the firm's innovation, while a higher leverage ratio had a negative impact on the innovation. No significant relation was found between leverage and employee well-being.

The second essay used the data from years 2004-2009, and inquired whether a higher entrepreneurial speed of learning is desirable, and whether there is a linkage between the speed of learning and growth rate of the firm. The change in the speed of 
learning was measured using a pooled OLS estimator in repeated cross-sections. There was evidence of a declining speed of learning over time, and it was concluded that a higher speed of learning is not necessarily a good thing, because speed of learning is contingent on the entrepreneur's initial knowledge, and the precision of the signals he receives from the market. Also, there was no reason to expect speed of learning to be related to the growth of the firm in one direction over another.

The third essay used the data from years 2004-2010, and determined the timing of diversification activities by the business start-ups. It captured when a start-up diversified for the first time, and explored the association between an early diversification strategy adopted by a firm, and its survival rate. A semi-parametric Cox proportional hazard model was used to examine the survival pattern. The results demonstrated that firms diversifying at an early stage in their lives show a higher survival rate; however, this effect fades over time. 


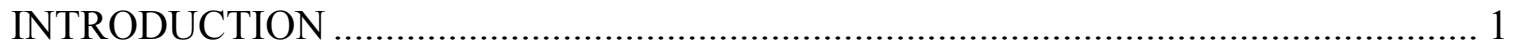

CHAPTER 1: IS “LEVERAGE” LEVERAGING THE BUSINESS START-UPS? ........ 6

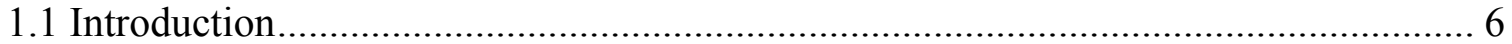

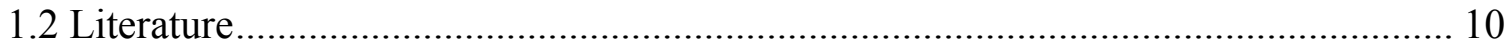

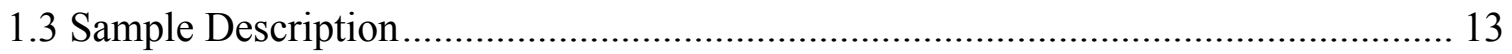

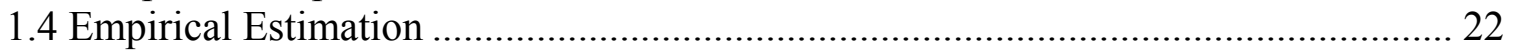

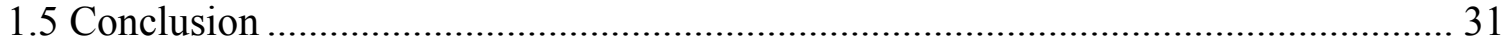

CHAPTER 2: SPEED OF ENTREPRENEURIAL LEARNING AND FIRM

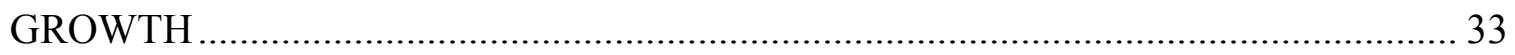

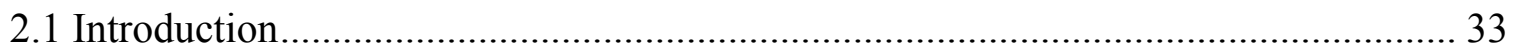

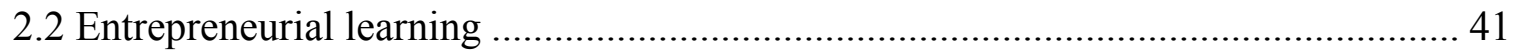

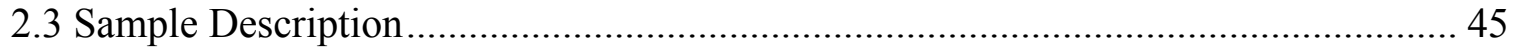

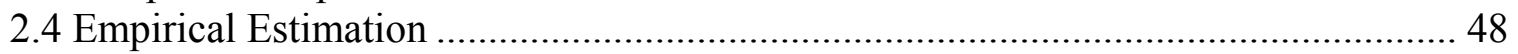

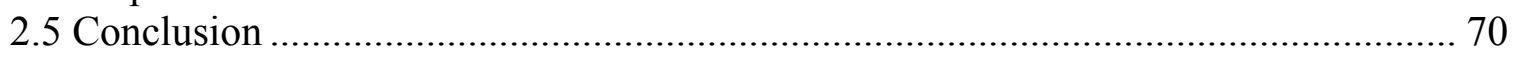

CHAPTER 3: DIVERSIFICATION AND SURVIVAL BY BUSINESS START-UPS 72

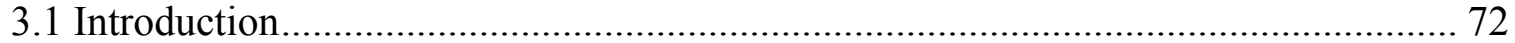

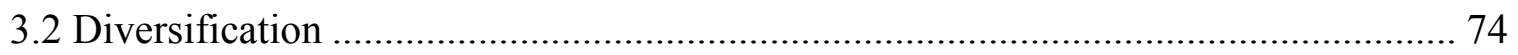

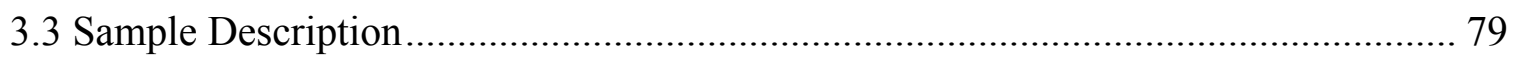

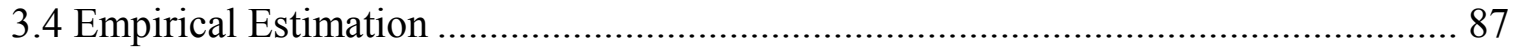

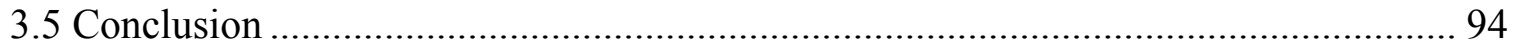

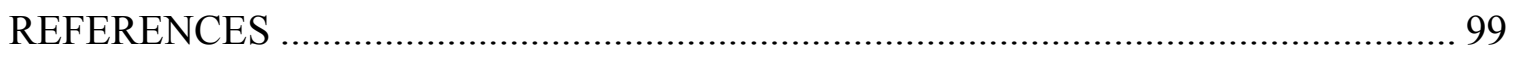

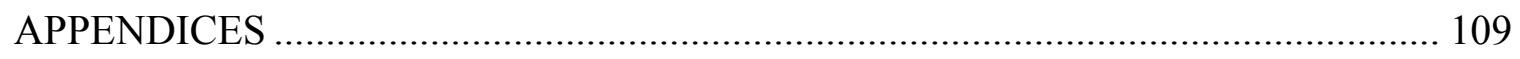

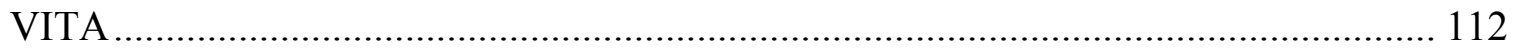




\section{LIST OF TABLES}

TABLE

PAGE

Table 1.1 Firms Going Out of Business ……………….......................................... 15

Table 1.2 Descriptive Statistics ............................................................................ 16

Table 1.3 Range of Debt-Equity Ratio …………………........................................... 18

Table 1.4 Results with Negative Binomial Fixed Effects Regression .............................. 25

Table 1.5 Results with Negative Binomial Fixed Effects Regression (After controlling

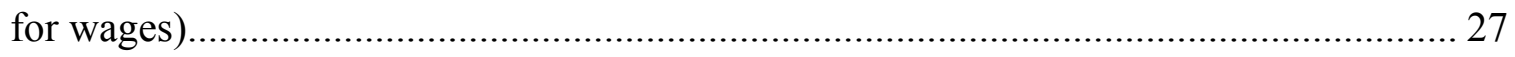

Table 1.6 Correlation between Employee Well-being \& Innovation ................................ 27

Table 1.7 Effect of Recent Financial Problems on the Firms ........................................... 29

Table 1.8 Regression Results for Leverage with Fixed Effects...................................... 30

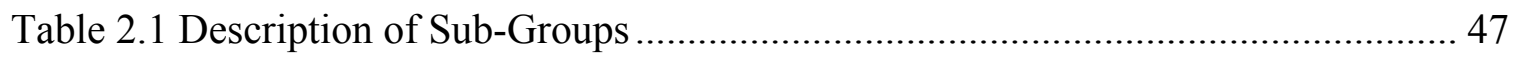

Table 2.2 (a) All firms: OLS - Pooled and Owner Specific............................................ 50

Table 2.2 (b) All firms: OLS - Firm Specific........................................................... 51

Table 2.2 (c) All firms: OLS - Industry Specific ……….............................................. 52

Table 2.3 (a) Surviving firms: OLS - Pooled and Owner Specific ................................... 54

Table 2.3 (b) Surviving firms: OLS - Firm Specific .................................................. 55

Table 2.3 (c) Surviving firms: OLS - Industry Specific................................................ 56

Table 2.4 (a) Comparison of surviving firms and entire sample using Pooled OLS

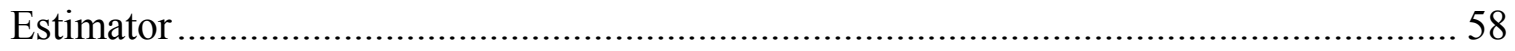

Table 2.4 (b) Comparison of surviving firms and entire sample using Pooled OLS

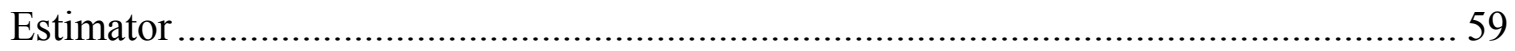


Table 2.4 (c) Comparison of surviving firms and entire sample using Pooled OLS

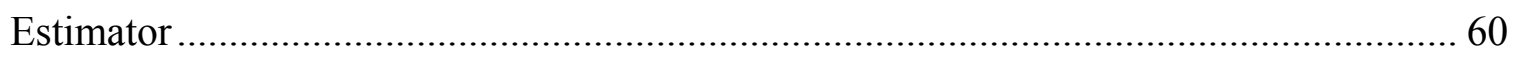

Table 2.5 Comparison of learning speed, growth rate $\&$ rate of survival: Surviving

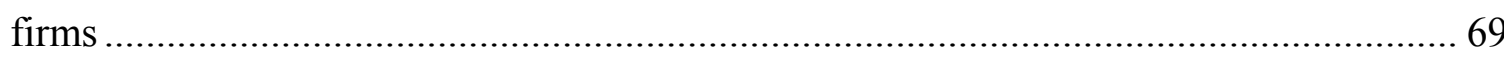

Table 3.1 Composition of the Final KFS Sample ………………….............................. 82

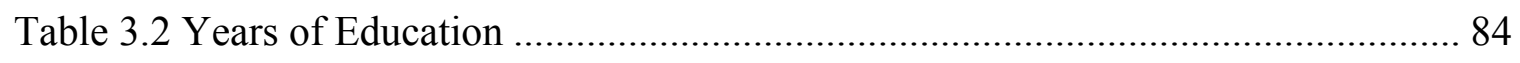

Table 3.3 Variable Definitions and Descriptive Statistics ............................................. 88

Table 3.4 Cox Proportional Hazard Estimates................................................................ 92 


\section{LIST OF FIGURES}

FIGURE

PAGE

Figure 1.1 Relation Between three variables, before analysis ................................... 13

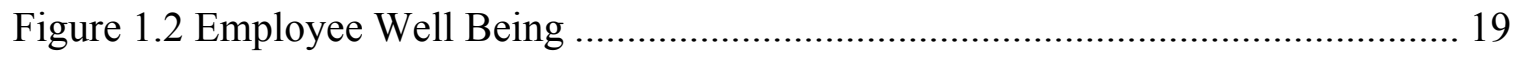

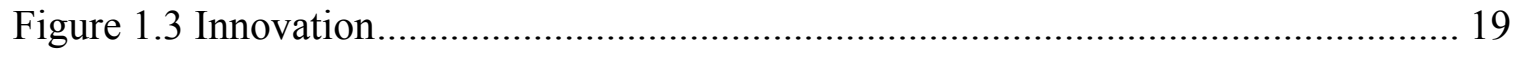

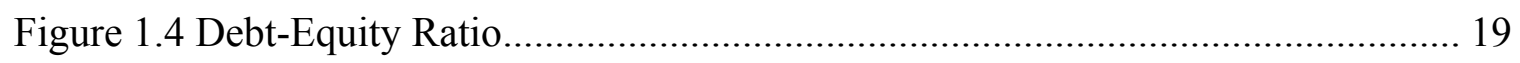

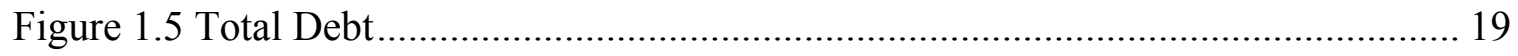

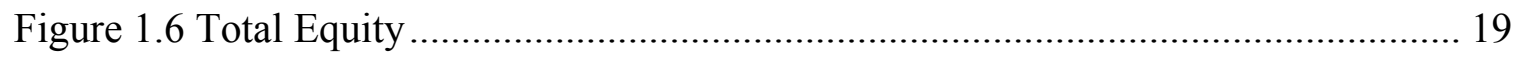

Figure 2.1 Speed of Learning for the Entire Sample ................................................ 49

Figure 2.2 Speed of Learning for the Surviving Firms ......................................... 50

Figure 2.3 Comparison Based on Groups .............................................................. 53

Figure 3.1 Survivor Functions, by Time Variant Diversification ................................ 89 


\section{LIST OF ABBREVIATIONS AND ACRONYMS}

$\begin{array}{ll}\text { ACES } & \text { Annual Capital Expenditure Survey } \\ \text { BLS } & \text { Bureau of Labor Statistics } \\ \text { CBP } & \text { County Business Patterns } \\ \text { DER } & \text { Debt Equity Ratio } \\ \text { EIN } & \text { Employer Identification Number } \\ \text { FICA } & \text { Federal Insurance Contributions Act } \\ \text { KFS } & \text { Kauffman Firm Survey } \\ \text { LMA } & \text { Labor Market Area } \\ \text { NAICS } & \text { North American Industrial Classification System } \\ \text { NORC } & \text { National Opinion Research Center } \\ \text { OLS } & \text { Ordinary Least Squares } \\ \text { ROA } & \text { Return on Assets } \\ \text { SBA } & \text { Small Business Administration } \\ \text { SIC } & \text { Standard Industrial Classification }\end{array}$




\section{INTRODUCTION}

Recent evidence shows that a large number of small businesses start every year, and approximately $40 \%-50 \%$ of them make it to their fifth year (Dunne et al., 1989; Knaup, 2007; Mata \& Portugal, 1994; Romanelli, 1989).

Amongst the firms that survive the initial years, a small percentage of them grow, innovate, and choose to diversify. Despite the growing interest in the young business survival and growth, little is known about the dynamics of a business start-up in the initial stages. Because of the complexity involved in the data collection, there has been an informational gap in the research between "small and young" firms, and "large and established" business formations.

In an effort to better understand the dynamics of new businesses in the United States, the Ewing Marion Kauffman Foundation sponsored the Kauffman Firm Survey (KFS), which is a panel study of new businesses founded in 2004 (Robb et al., 2010). The original sample in the KFS consists of 4,928 firms, and it contains detailed information on both, the entrepreneurs and the firms; making it the world's largest data on small businesses. Availability of the KFS makes it possible to analyze the founding conditions of the start-ups, and track their performance subsequent to their birth. These firms are at the cusp of childhood and adolescence, which makes the study of this unique data of special interest to both, researchers and policy makers alike. The dataset offers an opportunity to study a cohort of firms, all born in the same time period, maturing at the same pace, and facing the same macroeconomic shocks.

My dissertation makes use of the KFS dataset, and analyzes the dynamics of startups in the initial years. One of the important features of the KFS is that it adds data 
annually to the base year survey conducted in 2005. Consequently, three waves of data have been used to address three different issues relevant to the start-ups.

The first essay makes use of data from 2004-2008, and explores the linkage between: capital structure, innovation, and employee well-being. Business start-ups face credit constraints in the initial years of existence. One of the major reasons for this is their lack of credibility in the financial market. Regular supply of funds is important for the firm's survival and growth. In addition to the financial resources, organizational practices, and employee satisfaction likewise contribute to a higher level of innovation.

Accordingly, this essay examines the simultaneous relationship between the firm leverage $^{1}$ and employee well-being; and their impact on innovation. To measure the employee well-being, a set of nine dichotomous questions is used. These questions explore whether a firm provides fringe benefits to its employees or not. Total number of patents and copyrights held by a firm at the end of each year are used to measure the level of innovation. Firm leverage is calculated as total debt divided by the total financial resources.

A negative binomial fixed effects model is used to analyze the effect of employee well-being and leverage on the count data of patents and copyrights. The paper demonstrates that employee well-being positively affects the level of innovation. In contrast, a higher leverage ratio has a negative impact on the innovation. To counter the argument that non-monetary benefits act as a substitute for monetary payments, the study controls for the average wages. Even after controlling for the wages, the coefficient of employee well-being is positive and statistically significant. No significant relation is

\footnotetext{
${ }^{1}$ Leverage is the ratio of debt to equity.
} 
found between leverage and employee well-being. The argument of employee welfare guiding the debt-equity ratio does not work for young firms. Further, it is reported that because of varying debt levels and declining equity, leverage ratio rises with the age of the firm.

The second essay focuses on the speed of entrepreneurial learning. Researchers have shown that there is evidence that an entrepreneur learns the tricks of the trade as time passes. Efficient entrepreneurs identify the opportunities offered by the market, which gets reflected in the growth of the business. Building on this evidence, it becomes crucial to identify how fast an entrepreneur learns, and adjusts his beliefs to the new information received from the environment. Further, if an entrepreneur learns at a faster speed, does he generate better results for the business? These questions are unraveled by building on the model of entrepreneurial learning developed by Parker (2006). My study investigates whether the speed of entrepreneurial learning is the same across time and groups; and whether the firm's growth is altered by this learning.

Changes in the speed of learning are measured across factors measuring individual-, market-, and industry-specific characteristics. Initial six years (2004-2009) of data are used for the present study. Using a pooled OLS estimator in repeated crosssections, there is clear evidence of declining speed of learning over time, which is also in consonance with the framework of Bayesian learning. Results across the groups remain the same even after controlling for survivorship bias. It is concluded that a higher speed of learning is not necessarily a good thing, because the speed of learning is contingent on the entrepreneur's initial knowledge, and the precision of the signals he receives from the 
market. Also, there is no reason to expect speed of learning to be related to the growth of the firm in one direction over another.

The third essay focuses on the diversification activities undertaken by the young firms. There is an established line of research that explores the kind of diversification strategies firms adopt; motivation behind choosing diversification as a preferred strategy for growth; and measuring whether, and how it influences the performance of a firm (Ansoff, 1957, 1958; Chandler, 1962; Gort, 1962; Ramanujam \& Varadarajan, 1989; Montgomery, 1994; Palich et al., 2000). Most of these questions are answered for large and established firms; in contrast, there is a gap in the literature that deals with diversification activities undertaken by the young and small businesses. There are apparent differences in the large and small firms, and these differences become more prominent when compared with the business start-ups. Formulating policies for young businesses, based on empirical research on large firms will not yield accurate results (Lynn \& Reinsch, 1990). One of the questions that an entrepreneur of a young firm faces is: "When to diversify"? Therefore, third essay explores at what stage a business start-up diversifies, and whether there is an association between the timing of diversification, and firm survival.

To study the impact of industry concentration and urbanization in the labor market area, the County Business Patterns data from the U.S. Census Bureau is merged with the KFS. A Cox Proportional Hazard model is used to ascertain the relation between diversification and survival. The empirical results in this study provide evidence that majority of firms (62\%) diversify in the first year. Also, the firms diversifying at an early 
stage in their lives show a higher survival rate. However, this effect fades over time, and therefore shows no persistence.

My dissertation presents some policy recommendations to the organizations ${ }^{2}$ that provide financial support, training and assistance to the small and young businesses. In the first essay, fluctuating levels of debt imply lack of readily available funds. These organizations should try to provide a smooth flow of funds to business start-ups. The amount of collateral money for a loan should also be decreased for a start-up. Large amounts of collateral as a requirement de-motivates an entrepreneur to apply for funds. Further, there is a need to educate the entrepreneurs about the availability of loans and financial services; because $18 \%$ of the entrepreneurs in the study never applied for credit when they needed it (Robb et al., 2009).

An important implication gained from the second essay is that, it is advisable to guide and assist start-ups in the initial years when entrepreneurs are open to the concept of learning, and assign more weight to the market signals. There is evidence that early assistance and guidance does affect the venture performance (Roper \& Hart, 2005).

The third essay contributes to the existing knowledge of firm survival by adding the dimension of diversification, and its timing by business start-ups. Owners of the startups get a better perspective of when to diversify. Diversification can be a strategy for young firms seeking growth, or seeking a mere survival in the industry. In both cases, "when to diversify" is an important decision that an owner has to make. Owners will be better able to evaluate their chances of success, once they know when to undertake diversification activities.

\footnotetext{
${ }^{2}$ The Small Business Administration, The SCORE Association (Service Corps of Retired Executives), The Kauffman Foundation, The Coleman Foundation.
} 


\section{Chapter 1: Is "Leverage" Leveraging the Business Start-ups?}

\subsection{Introduction}

Innovation is considered to play a crucial role in the firm's survival and growth. For established firms, innovation is a way to retain their competitive edge in the market (Christensen, 1997); and for young firms, it is a way to discover new products and services in new markets (Cefis \& Marsili, 2005). Highlighting the relevance of innovation, Porter (1990) mentions that, one of three cornerstones of global competitiveness is innovation; the other two being continuous improvement and change.

Researchers have investigated the factors that affect a firm's level of innovation. Over the years, various reasons have come up that range from, the size of the firm to the structure of the market (Acs \& Audretsch, 1987; Cohen \& Klepper, 1996; Huynh et al., 2008; Koski et al., 2009; Petersen \& Rajan, 1994; Smith, 2010).

However, there is a gap in the literature that addresses the impact of two variables together on innovation. These are: financial structure and human resource policies. This paper addresses the linkage between capital-mix ${ }^{3}$ and employee well-being, and their simultaneous impact on the level of innovation. My study is motivated from the literature on the above mentioned two variables, whose effect on innovation has been examined individually, however, have never been analyzed together.

Analyzing the first linkage, controlling for the initial level of patents and copyrights, Smith (2010), analyzes the role of bank loans and debt, and their subsequent relation to the level of innovation. Using a logit analysis, she registers a positive impact of leverage on innovation.

\footnotetext{
${ }^{3}$ Capital mix is the ratio of debt to equity (DER), and is also known as leverage, DER=Debt/(Debt+Equity)
} 
Further, in addition to the financial resources, human resource policies also affect a firm's performance (Laursen \& Foss, 2003; Therrien, 2003). Organizational structure and human resource practices that foster new ideas in the workers can help a firm in achieving a higher level of innovation. Human resource practices per se might not generate innovation, but they do motivate employees to come up with new ideas (Zoghi et al., 2010). Therefore, it justifies studying the impact of these human resource practices and employment relations on innovation, in addition to the financial resources.

Following the importance of human resource practices, Koski et al., (2009) in their study on 398 Finnish firms, explore the linkage between organizational factors and innovation. They find that practices that improve employee welfare affect innovation positively in small firms, whereas, large firms do not show this positive effect. They conclude that large firms have a decentralized decision-making structure that does not motivate employees.

Linking up the above two variables that affect innovation, Verwijmeren \& Derwall (2009) suggest an inverse relationship between employee well-being and leverage. Using the KLD STATS database for their study, they argue that the risk of bankruptcy, which is bad for employees, motivates a firm to keep lower levels of leverage. They indicate that firms experience financial distress when they cannot fulfill their fixed financial payments in the form of debt. Therefore, in an event of bankruptcy, employees have to suffer monetary losses, and face the risk of losing their jobs. Consequently, firms that care more about its employees will take lower amounts of debt, and inject higher amounts of equity, which will eventually reduce the probability of bankruptcy. 
Observing the associations in the above-mentioned studies, the present essay examines a three-way linkage between, firm leverage, innovation, and employee wellbeing, amongst the firms that are in their fifth year of existence. Start-ups face a higher risk of bankruptcy, and eventual exit from the market. The questions examined in this study are: will a start-up formulate a policy lower debt level just because it cares for its employees; or choose a capital mix ratio that will yield a higher level of innovation?

Analyzing the first linkage longitudinally, this study reports that, for young firms, higher leverage has a negative impact on the level of innovation, whereas, a favorable human resource policy affects innovation positively. However, the same set of policies has no impact on the capital mix of the firm. Therefore the argument of employee welfare guiding the debt-equity ratio does not work for young firms. Even though the index measuring the well-being of employees increases, leverage shows an upward trend. The risk of bankruptcy pressing a firm to have lower levels of debt would be justified for large publicly traded firms, but does not seem to be a reasonable answer in case of small and young firms.

Results of this analysis contribute to the literature in four ways. First, the study documents an important role played by leverage for young firms; and the risk associated with higher amounts of debt and lesser equity levels. In the current paper, leverage ratio increases with the age of the firm, whereas a fluctuating pattern is witnessed for total debt. Equity on the other hand, tends to decline with the age of the firm. Further, with capital constraints binding in the initial years, young firms do not target at an "optimal 
ratio" $" 4$ of external borrowings to financial resources. Fluctuating level of debt, along with decreasing equity, obstructs the regular supply of funds, thereby preventing innovation by start-ups.

Second, an increase in leverage should be interpreted with caution, because the increase can come either from increasing the debt, or by decreasing the owner's equity. Changing levels of debt does not allow a firm to take advantage of the leverage that comes with using debt as a part of its capital structure. Further, small and young firms lack the cushion that can support them in case of a macroeconomic shock. Therefore, the trend depicted by both, debt and equity, is justified when linked to the financial turmoil in 2007, and the current economic environment.

Third, from the perspective of the organizations that lend and assist small and young businesses, fluctuating levels of debt imply the lack of readily available funds. Debt being the largest source of funding for the firms in the KFS highlights the importance of liquid credit markets. But fluctuating levels of debt also point towards a lack of regular flow of funds. The reason for this is, when asked during the survey, owners reported that, in most cases their loan applications were denied because of lack of collateral, and poor credit history. Owners also reported that their applications were denied because of inadequate documentation and even on the basis that it is a new business. These organizations should try to provide a smooth flow of funds to business start-ups. Large amounts of collateral as a requirement makes it difficult for an entrepreneur to consider a loan as a measure of finance.

\footnotetext{
${ }^{4}$ There is no exact value of debt-equity ratio which can be termed as optimal; generally it varies with industries.
} 
Further, there is a need to educate the entrepreneurs about the availability of loans and financial services. Approximately $18 \%$ of the entrepreneurs in the study never applied for credit when they needed it. Owners mentioned that they were pessimistic about their loan application, and thought that it would be denied. Therefore, entrepreneurs should be made aware of the available financial resources, and motivated to apply for debt, which is a lesser expensive option when compared to equity.

The remainder of this paper is organized as follows: Section 1.2 gives a detailed analysis of the three variables and linkages involved in them. Section 1.3 describes the data and how the indices of employee well-being and innovation are constructed. The empirical estimation in section 1.4 is followed by the conclusion in section 1.5.

\section{$1.2 \quad$ Literature}

Differences in the intellectual property between large and small firms have been considered to originate from the differences in the market concentration, barriers to entry, cash flows, and firm size (Acs \& Audretsch, 1987; Cohen et al., 1989; Cohen \& Klepper, 1996; Galbraith, 1952; Himmelberg \& Petersen, 1994). Despite intensive research into this area, there is no agreement on whether it is large or small firms that are more innovative, and undertake more research.

Regardless of the firm's size, finance plays an important role in survival, and future growth of the firm. With current research ${ }^{5}$ incorporating financial frictions into the study of firm dynamics, it becomes useful to include the capital structure of a firm while

\footnotetext{
${ }^{5}$ Cooley and Quadrini (2001) added financial frictions in the study of firm dynamics and found that leverage ratios decline with firm's age. Hopenhayn (1992), Albuquere and Hopenhayn (2004) included financial constraints into the study of firm growth and survival. Huynh and Petrunia (2010) extended the work of Hopenhayn (1992) and studied the impact of debt-to-asset ratio on firm's growth and found a positive and non-linear relation between them. Cabral and Mata (2003) also studied the impact of financial constraints on size dynamics.
} 
analyzing the innovation levels. Innovation activities by small and young firms are often restrained by inadequate funds. The literature has linked the capital-mix puzzle with the level of research and development (R\&D) activities a firm undertakes. Examining the effect of leverage on the listed firms in the U.S., Singh \& Faircloth (2005) show that leverage affects R\&D negatively. Using a German dataset, Czarnitzki \& Kraft (2004) also document a negative influence of leverage on research and development. In a crosssectional analysis considering the R\&D activities of high-technology firms, Chiao (2002) finds a negative impact of debt. Yet, for non-high-technology companies, he finds a positive impact. In contrast, Mac An Bhaird \& Lucey (2006), using data on Irish firms, find no relation between R\&D activities and leverage. There are contradictory results with different datasets, and different geographical locations.

But does the capital-mix really matter for business start-ups? Do young businesses actually set their debt-equity mix, keeping in mind what level of innovation they want to achieve? Generally firms focus not just on financial capital, but also include the aspect of human capital while deciding the level of innovation. This justifies including the effect of human resource policies, along with the effect of financial structure on innovation in this study.

Researchers have reported that interactive human resource practices (Black \& Lynch, 2004), better employee-management communications, decentralized decisionmaking (Laursen \& Foss, 2003), information-sharing programs, and incentive pay plans (Zoghi et al., 2010) increase innovation. Despite the fact that better human resource polices promote innovation, studies reported above fail to account for them in their analysis. 
Researchers who believe that innovation is a function of a firm's ability to create, manage, and maintain knowledge (Smith et al., 2005), assign all the weight to the human resources and policies affecting them (Koski et al., 2009). Lazear \& Oyer (2007) suggest that, "good performance can then be rewarded through a variety of mechanisms, including increases in base salary, subjectively determined bonus payments, or promotions."

Further, there is supporting evidence in the literature that a higher level of leverage puts the employees of the company at risk (Berk et al., 2010; El Ghoul et al., 2010). When a company goes bankrupt, one of the most pressing issues for the liquidators is how much compensation will go to the employees. In line with the above argument, this study examines, are there any "human costs to bankruptcy" (Berk et al., 2010)?

The three variables discussed above have been well researched and tested for their significance individually. However, the linkages between leverage, employee well-being, and innovation have not been held to an empirical scrutiny with one coherent data-set, especially for business start-ups. Linking up the three directions, there seems to be some discrepancy between employee well-being and leverage on one hand, and innovation and leverage on the other (Figure 1.1).

My study explores how employee well-being, which is purely a subjective measure; and leverage, which deals with the financial structure, affects the innovation trajectory of the start-ups. The next section describes the sample, and how these variables are created. 


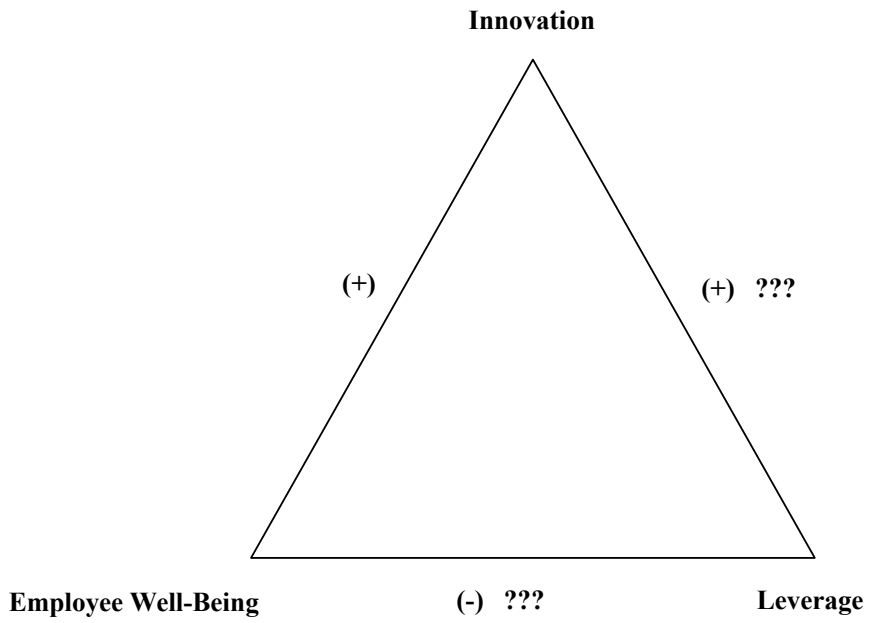

Figure 1.1 Relation Between three variables, before analysis

\subsection{Sample Description}

\subsubsection{Data-set}

The study uses the KFS, which is a panel data on 4,928 firms, all of which began operation in year 2004. Because all the firms in the KFS started at the same time, the data do not suffer from inherent survivor bias (Smith, 2010). At the end of the project, the KFS will contain a detailed data record spanning the period of 2004-2013. The base-line survey was conducted in 2005, and since then there have been six subsequent follow-ups. The sample size has declined over these years with reasons varying from, problems in locating a firm in the follow-up periods, non-responses, or because of a firm's exit. In the survey, for a firm to be considered as a start-up it should have satisfied any of the five criteria in 2004: (i) paid state unemployment taxes, (ii) paid Federal Insurance Contributions Act (FICA) Taxes, (iii) had a legal status, (iv) used an Employer 
Identification Number EIN, or (v) used schedule $\mathrm{C}$ to report business income. A firm is excluded from the survey if it reports any of these five criteria prior to $2004^{6}$.

To ensure that only start-ups were included in the survey, owners were asked ${ }^{7}$ to report whether the business (i) was started as a new business, branch or a subsidiary owned by an existing business, (ii) was inherited, (iii) was started as a new independent business, (iv) was purchased as an existing business or, (v) was purchased as a franchise, (vi) or was an organization designed for social and charitable objectives and established as "non-profit". If the responses fell under category (i), (ii) or (vi), respondents were excluded from the sample.

The present study focuses on data collected in the first five years of a firm's existence (calendar years 2004-2008). It accounts for firm attrition, and only includes permanent failure. Refusals and non-responses have also been excluded from the data-set to maintain consistency in defining failure. Accordingly, 191 firms (see Table1.1) are taken out from the sample because, (i) they temporarily went out of business, (ii) of nonresponse/refusal, (iii) they were merged with another business or sold, or (iv) they had missing data. Further, 76 firms are dropped from the sample because they reported no sales or revenue in all these years.

Moreover, 20 firms are dropped that reported no owner ${ }^{8}$ in all five years. A total of 1,110 firms are lost as natural attrition. Also, firms with no funds in the business are taken off from the sample, and accordingly a total of 55 firms are deleted. One can argue

\footnotetext{
${ }^{6}$ For details on survey design and construction, refer to DesRoches et al., (2008); Robb et al., (2009, 2010)

${ }^{7}$ A detailed set of questions asked during the survey, relevant to this study has been listed in the Appendix

${ }^{8}$ Owner has been defined as a person who is actively involved in running the business
} 
that firms operating in the services sector may not require a significant percentage of funds or assets to operate. Keeping this in mind, their level of sales, revenue generated, and profit made, was cross-checked, and they all recorded a zero value. By the end of the fifth year, the sample size is reduced to 3,361 firms.

Table 1.1 Firms Going Out of Business

\begin{tabular}{lrrrr}
\hline Firms Going Out of Business: Description & $\mathbf{2 0 0 5}$ & $\mathbf{2 0 0 6}$ & $\mathbf{2 0 0 7}$ & $\mathbf{2 0 0 8}$ \\
Sold & 0 & 0 & 0 & 23 \\
Merged & 0 & 0 & 0 & 14 \\
Temporarily stopped working & 18 & 20 & 41 & 73 \\
Unspecified Reason & 0 & 1 & 0 & 1 \\
No Owner in all 5 years & - & - & - & 20 \\
No Revenue in all 5 years & - & - & - & 76 \\
No Funds invested in all 5 years & - & - & - & 55 \\
Natural Attrition & - & - & - & 1,110 \\
\hline
\end{tabular}

\subsubsection{Variable Construction}

\subsubsection{Index of employee well-being}

To measure favorable human resource policies in the firm, an index of employee well-being is constructed. It is derived from a set of nine dichotomous questions asked during survey. These include, did the business offer: (i) a bonus plan to its employees, (ii) an alternative work schedule, (iii) a health insurance plan, (iv) other benefits, (v) paid sick days, (vi) paid vacations, (vii) a retirement plan, (viii) stock options, and (ix) tuition reimbursement. 
Responses to these questions are coded as "yes" $=1$, and "no" $=0$. The counts of "1" are added to create an index for employee well-being. The KFS reports information on both full-time and part-time employees. Therefore, for each set of employees, there are nine questions. The index of well-being can take a minimum value of " 0 " when the answer to all the questions is "no", and the maximum of eighteen, where all the questions are answered as "yes", and each get a score of "1" (for both full-time and part-time employees). Figure 1.2 shows the pattern of index of employee well-being over five years, where it is increasing for the first four years, and then shows a slight decline in the fifth year. Descriptive statistics of variables are provided in Table 1.2.

Table 1.2 Descriptive Statistics

\begin{tabular}{lcccr}
\hline \multicolumn{1}{c}{ Variables } & Mean & Min & Max & S.D. \\
\hline Firm Size & & & & \\
Number of Employees & 2.96 & 0 & 55 & 5.65 \\
Full Time Employees & 2.08 & 0 & 40 & 4.68 \\
Part Time Employees & 0.87 & 0 & 28 & 2.33 \\
Revenue (x 100,000) & 2.47 & 0 & 10 & 3.18 \\
Asset Structure & & & & \\
Intangible Assets & 0.35 & 0 & 5 & 0.48 \\
Total Assets (x 100,000) & 2.19 & 0 & 10 & 2.97 \\
Financial Structure & & & & \\
Leverage (Debt/Total Financing Sources) & 0.41 & 0 & 1 & 0.44 \\
Firm-Specific Variables & & & & \\
Credit Rating & 2.91 & 1 & 5 & 0.92 \\
Innovation (Sum of patents \& Copyrights) & 1.71 & 0 & 250 & 12.90 \\
Employee Well-Being & 2.67 & 0 & 17 & 5.65 \\
Entrepreneur Specific Variables & & & & \\
Work Experience & 13.74 & 0 & 40 & 10.47 \\
Education & 15.07 & 0 & 21 & 2.71 \\
Age & 46.81 & 21 & 79 & 10.71 \\
\hline
\end{tabular}




\subsubsection{Level of innovation}

The KFS distinctly asks the owners to report, "How many patents and copyrights does the business have at the end of the year?" This constructed variable measures the total number of patents and copyrights held by a firm at the end of each year and is used to measure innovation. Patents and copyrights are one of the most commonly used methods to assess the level of intellectual property of a firm (Acs et al., 2002). However, there are two issues that could not be addressed with this variable construction. First, the nature of the data-set does not allow identifying the patent citations. Therefore, patent quality as an issue could not be addressed in the study (Trajtenberg, 1990). Second, the survey does not report how many patents and copyrights did the firm apply for, and how many were obtained. So, there is no way to demarcate the patents applied for, and actual patents granted. Figure 1.3 shows the pattern of this constructed variable measuring innovation, where in year 2006 and 2007, there is a sharp increase in innovation, followed by a sharp decline in 2007 .

\subsubsection{Financial variables and firm-specific controls}

Firm leverage is calculated as total debt divided by the total financing resources. Total debt includes: (i) total debt by the owner, and (ii) total business debt. Total debt (see Figure 1.5) of the owner includes: (i) personal credit card balances, (ii) personal loans obtained from bank or family members or any other creditor, (iii) business credit cards under which owner is accountable. Total business debt includes: (i) credit card balances established for the business, (ii) bank loans for the business, (iii) credit line of business, and (iv) any other kind of loans taken under the business name (such as family, 
government, employees, other businesses). Total financial resources are a sum of total debt and total equity. Total equity (see Figure 1.6) includes total asset base of the firm: (i) total equity of the owner operator, and (ii) total equity of the non-owner operators.

Debt remained the dominant source of financing for start-ups, which is evident from the fact that in the first year alone, firms injected around $\$ 80,000$ worth of resources in the form of debt. Leverage shows a sharp increase in the first follow-up year. The same pattern is witnessed in the rest of the follow-up years (see Figure $1.4 \&$ Table 1.3).

To overcome the problem of non-response, the KFS uses range values ${ }^{9}$ if the respondent could not, or would not provide the answer regarding the exact figure. Therefore, midpoints from these ranges are used to calculate total debt and total equity. A midpoint from the range values has been used earlier, and is supported by the literature (Kennickell, 1997; Lemieux et al., 2009).

Table 1.3 Range of Debt-Equity Ratio

\begin{tabular}{lrrrrr}
\hline Debt-Equity Ratio (DER) & $\mathbf{2 0 0 4}$ & $\mathbf{2 0 0 5}$ & $\mathbf{2 0 0 6}$ & $\mathbf{2 0 0 7}$ & $\mathbf{2 0 0 8}$ \\
Number of firms with zero DER & 1,450 & 1,296 & 1,178 & 1,130 & 1,058 \\
Number of firms with DER $=0.5$ & 476 & 235 & 187 & 129 & 128 \\
Number of firms with DER $=1$ & 329 & 704 & 796 & 805 & 811 \\
\hline
\end{tabular}

\footnotetext{
${ }^{9}$ Range definition: (Range-Value) (1- $\$ 500$ or less) (2- $\$ 501$ to $\left.\$ 1,000\right)(3-\$ 1,001$ to $\$ 3,000)(4-\$ 3,001$ to $\$ 5,000)(5-\$ 5,001$ to $\$ 10,000)(6-\$ 10,001$ to $\$ 25,000)(7-\$ 25,001$ to $\$ 100,000)(8-\$ 100,001$ to $\$ 1,000,000)$ $(9-\$ 1,000,001$ or more)
} 


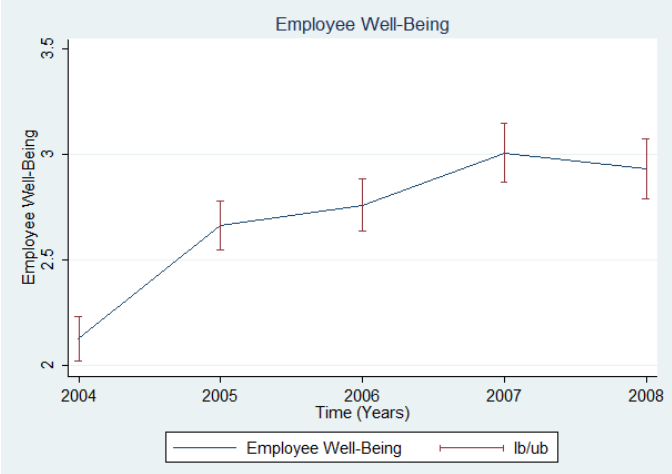

Figure 1.2 Employee Well Being

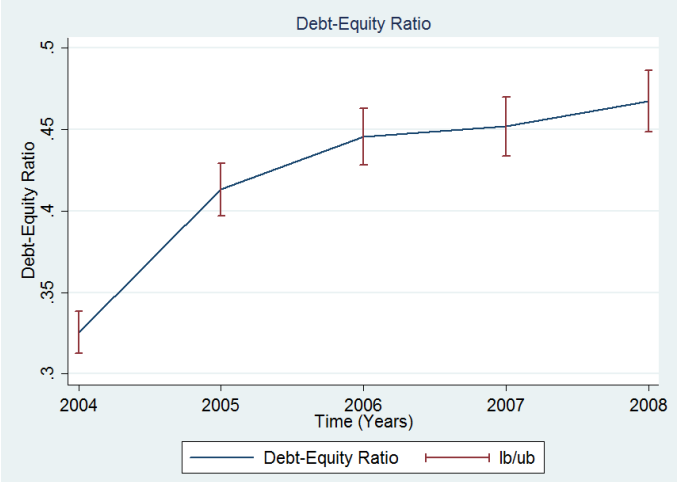

Figure 1.4 Debt-Equity Ratio

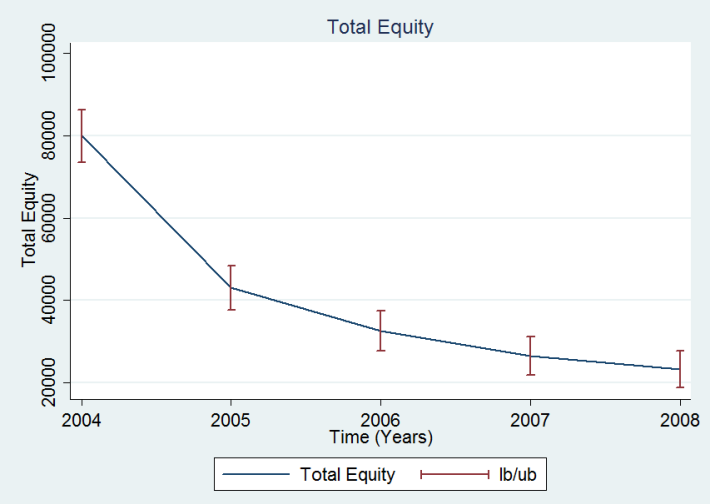

Figure 1.6 Total Equity

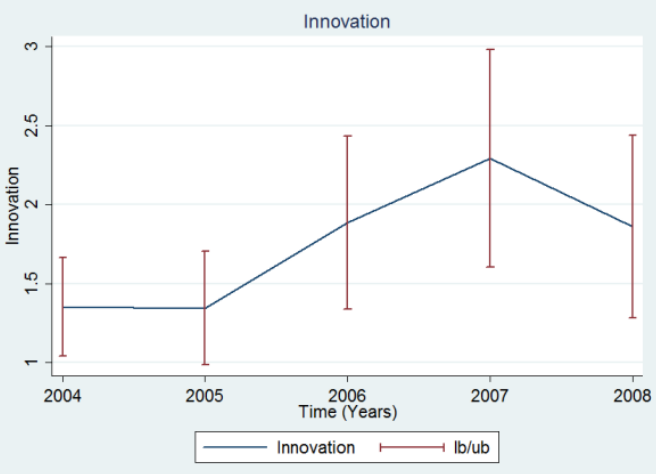

Figure 1.3 Innovation

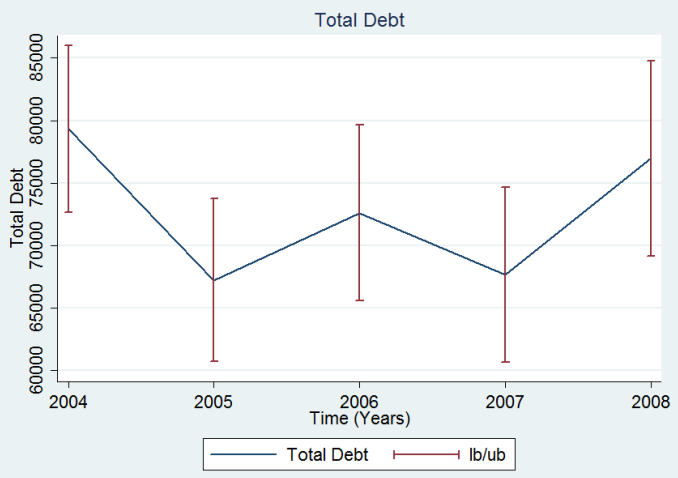

Figure 1.5 Total Debt 
Research and Development (R\&D) expenditure is generally considered as a primary measure of innovative activity (VanPraag \& Versloot, 2007). To capture the extent to which a firm is committed to improving its technological capabilities, a measure of intangible assets is included. It is calculated by dividing the number of employees in the R\&D section, by the total number of employees in the firm. Initial asset base is a cause of divergence in survival and growth rates of the firms. Firms with a large initial asset base can provide the necessary funds required for innovation. Therefore, total assets are included in the study. Following the literature, total number of employees is used to represent the firm size (Geroski et al., 2007; Mata and Portugal, 1994). Owners are excluded while calculating total number of employees. To account for the financial stability of a firm, the study incorporates credit ratings of the firms. Credit rating can take a values from 1 to $5, " 1 "=$ worst and " $5 "=$ best. These credit ratings are provided by Dun \& Bradstreet.

Further, the legal form of a firm is also controlled for. Approximately $36 \%$ of the firms in 2004 , and $34 \%$ in 2008 , operate as sole proprietorships, and the rest of them are established as limited liability companies, partnerships and corporations.

\subsubsection{Entrepreneur-specific variables and controls}

There is a detailed set of information on demographics of up to fourteen owners in the Kauffman Firm Survey. "About $65 \%$ of the KFS firms had just one owner, while 26\% had two, and 9\% had three or more owners in 2004" (Robb et al., 2008). In case of multiple owners, rather than averaging their values, or averaging the weighted shares of

the business, the main owner of the firm is identified using a positive sorting. The main 
owner is estimated on the basis of who puts in the maximum work effort, a figure calculated by using the number of hours each owner worked per week. In case there is a tie on the number of hours worked, work experience is used to resolve that tie. Further ties are resolved on the basis of maximum education and equity share. As a result of this rank ordering, gender, age and ethnic origin of the main owner is clearly identifiable.

The general level of human capital is assessed on the basis of the main owner's education and prior work experience. Owners were asked, "How many years of working experience have you had in this industry - the one in which the business competes?" and their responses ranged from 1 to $40+$ (more than 40 years).

\subsubsection{Industry-specific variables}

The nature of the industry in which a firm operates also affects its ability to innovate. Generally, high-technology companies are considered to infuse a higher number, and a higher quality product as compared to non-high-tech firms. With oversampled high-technology firms in the data, the firms are classified as "high-tech" and "non-high-tech", where hi-tech is a dummy variable, and takes the value " 1 " if a firm belongs to the high-tech sector, or " 0 " otherwise. The classification is derived from matching the North American Industrial Classification System (NAICS) with Heckler's (2005) classification. For a firm to be called as a high-tech firm it should either be a technology-employer ${ }^{10}$ or a technology-creator.

\footnotetext{
${ }^{10}$ Two sets of criterion are used to define high-technology industry, (i) Following Chapple et al. (2004), industries where employment exceeds three times the national averages of $3.33 \%$, or $9.98 \%$ is labeled as "technology-employer" and, (ii) Based on NSF's Survey of Industrial Research and Development an industry is termed as "technology-creator" if it exceeds the U.S. average for both research and development expenditures for employee $(\$ 11,972)$ and the proportion of full-time-equivalent $R \& D$ scientists and engineers in the industry workforce $(5.9 \%)$.
} 


\subsection{Empirical Estimation}

\subsubsection{Research design}

On the basis of the above discussion, the count data on innovation that comprises of number of patents and copyrights may be specified as follows:

$$
I=f\left(\beta_{1} w, \beta_{2} x, \beta_{3} z\right)
$$

Where, $I$ is the level of innovation; $\beta_{1}, \beta_{2}, \beta_{3}$ are the parameter vectors, and $w$ is a set of determinants of innovation related to policies that promote employee well-being; $x$ captures the leverage, and $z$ is a set of standard variables used in the literature to explain the innovative performance of firms. The operational model is:

$$
\begin{aligned}
& y_{i t}=\alpha w_{i t}+\delta z_{i t}+\eta v_{i t}+\lambda s_{i}+\theta_{i}+\mu_{i t}, \\
& i=1, \ldots, n \quad t=1, \ldots, 5 \quad \text { where, } \\
& y_{i t}=\text { is the level of innovation of firm } i \text { at time } t \\
& w_{i t}=\text { index of employee well-being of firm } i \text { at time } t \\
& z_{i t}=\text { debt-equity ratio of firm } i \text { at time } t \\
& v_{i t}=\text { time varying characteristics at time } t \text { like age and experience } \\
& s_{i}=\text { time invariant characteristics at time } t \text { like education, race, and gender } \\
& \theta_{i}=\text { unobserved individual effect (firm dynamics in nascent stages) } \\
& \mu_{i t}=\text { residual }
\end{aligned}
$$

The firms in the data are in their initial years of existence, therefore, a small number of patents and copyrights are generated. Approximately $80 \%$ of the firms have a count of zero patents and copyrights. There are two options to evaluate a count model with preponderance of zeros: the negative binomial regression, and the zero inflated 
negative binomial regression. Both the Bayesian Information Criterion (BIC) and the Akaike Information Criterion (AIC) favored the negative binomial regression in this study. A Hausman test is then conducted to test the efficiency of fixed over random effects. To ascertain the impact of employee well-being on innovation, negative binomial fixed effect estimator is used. The estimated standard errors have been adjusted for heteroscedasticity. Further, to test the second linkage between firm's leverage and employee well-being, firm specific fixed effects are used. It should be noted that only those firms are included for analysis that made it to their fifth year. Therefore, the sample consists of all the successful firms, which shows the presence of selection bias.

\subsubsection{Empirical results}

The study investigates the correlation between a firm's financial structure, employee well-being, and innovation. It aims at explaining whether young firms actually consider the debt-equity ratio and employee welfare while deciding their level of innovation. Table 1.4 presents the estimation results of the first model exploring innovation as the outcome.

The sample size is reduced to 1,151 observations because of preponderance of zeros in the estimation model. Further, out of 1,151 observations, 943 observations are for high-technology firms because the original sample is oversampled with hightechnology firms. A similar result is observed while calculating the effect of employee well-being on firm leverage, where 1,725 observations out of a total of 2,464 observations are high-technology firms.

Table 1.4 shows that for all firms, as well as for high-technology firms, the estimated coefficient of employee well-being is positive and statistically significant. 
Confirming the first linkage, the estimated model documents a positive effect of employee well-being on innovation. To counter the argument that non-monetary benefits act as a substitute for monetary payments, average wages paid by a firm are controlled in the study. Even after controlling for wages, the coefficient of employee well-being is positive and statistically significant. Results after controlling for wages are reported in Table 1.5.

The coefficient on firm size, which is a sum total of full-time and part-time employees is not significant. One argument could be that the majority of these firms have no employees at all, and are operated by a single owner, thereby bringing down the effect of size on innovation. In addition, the total asset base of the company has a significant and positive effect on innovation. A large asset base gives the firm leverage to exploit its resources, and deploy them for R\&D activities.

Figure 1.7 Relation Between three variables using the KFS

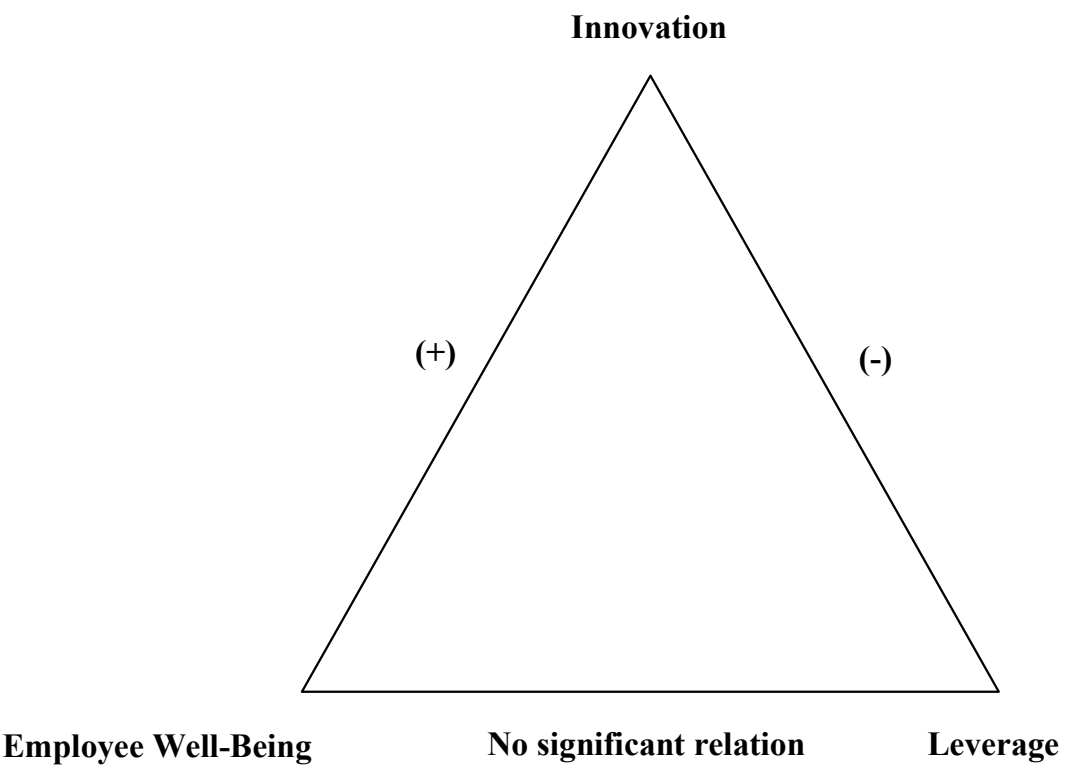


Table 1.4 Results with Negative Binomial Fixed Effects Regression

\begin{tabular}{lcc}
\hline \multicolumn{1}{c}{ Dependent Variable } & Innovation & \\
\hline VARIABLES & $\mathbf{( 1 )}$ & $\mathbf{( 2 )}$ \\
Employee Well Being & All Firms & High-tech Firms \\
Debt-Equity Ratio & $0.050^{* * *}$ & $0.042^{* *}$ \\
& $(0.019)$ & $(0.021)$ \\
Total Assets & $-0.309^{* * *}$ & $-0.258^{* *}$ \\
& $(0.109)$ & $(0.118)$ \\
Size & $5.30 \mathrm{e}-0^{* * *}$ & $6.53 \mathrm{e}-0^{* * *}$ \\
Intangible Assets & $(1.86 \mathrm{e}-0)$ & $(2.03 \mathrm{e}-0)$ \\
& -0.001 & -0.007 \\
Credit Rating & $(0.008)$ & $(0.008)$ \\
& 0.059 & 0.016 \\
Age of the Owner & $(0.068)$ & $(0.074)$ \\
Work Experience & 0.015 & 0.057 \\
Constant & $(0.056)$ & $(0.061)$ \\
Number of Firms & $0.022^{* *}$ & 0.014 \\
\hline & $(0.008)$ & $(0.008)$ \\
& -0.007 & -0.010 \\
& $(0.010)$ & $(0.010)$ \\
& $-1.706^{* * *}$ & $-1.356^{* * *}$ \\
& $(0.405)$ & $(0.437)$ \\
& 1,151 & 943 \\
& 345 & 284 \\
\hline
\end{tabular}

Standard Errors are reported in parentheses. ${ }^{* * *}, * *, *$ denote variables statistically significant at the 1,5 and $10 \%$ level respectively

Generally, intangible assets are associated with a higher level of innovation. However, in this study, no significant impact of intangible assets is found. Intangible assets are constructed as a proportion of employees working in the area of R\&D, scaled by the total number of employees in the firm. Linking this result with the size of the firm, 
it can be inferred that the observations on total number of employees in general, and R\&D in particular are not sufficient to generate significant effect on innovation.

A word of caution while interpreting the results is that the direction of causation may reverse from innovation to employee well-being. Studies have always taken human resource practices and incentives as a causal variable. To justify the causality between employee well-being and innovation in this case, a procedure used by Wyatt (2002) is employed. To see in which direction the relationship runs between employee well-being and innovation, two different correlations are compared: (i) Correlation A represents the relationship between the 2004 employee well-being score and 2005 innovation level, and (ii) Correlation B represents the relationship between 2004 innovation level and 2005 employee well-being score (see Table 1.6).

If higher innovation level is what generates a higher employee wellness, Correlation B should be larger. In contrast, the way companies manage their human capital is what drives the innovation, Correlation A should be larger. In this study, (i) Correlation A (0.0681) is larger than (ii) Correlation B (0.0664). Although, the difference is marginal, a higher correlation A shows the "temporal precedence" of employee wellbeing when compared with innovation. To explore the relation longitudinally, an instrumental variable technique should be deployed. However, due to limitations in the KFS, this technique cannot be used. 
Table 1.5 Results with Negative Binomial Fixed Effects Regression (After controlling for wages)

\begin{tabular}{|c|c|c|}
\hline Dependent Variable & & \\
\hline \multirow{2}{*}{ VARIABLES } & (1) & (2) \\
\hline & All Firms & High-tech Firms \\
\hline \multirow[t]{2}{*}{ Employee Well Being } & $0.047 * *$ & $0.041^{*}$ \\
\hline & $(0.020)$ & $(0.022)$ \\
\hline \multirow[t]{2}{*}{ Debt-Equity Ratio } & $-0.317 * * *$ & $-0.253 * *$ \\
\hline & $(0.110)$ & $(0.120)$ \\
\hline \multirow[t]{2}{*}{ Total Assets } & $4.28 \mathrm{e}-0 * *$ & $5.89 \mathrm{e}-0 * * *$ \\
\hline & $(1.96 \mathrm{e}-07)$ & $(2.15 \mathrm{e}-07)$ \\
\hline \multirow[t]{2}{*}{ Size } & -0.003 & -0.002 \\
\hline & $(0.008)$ & $(0.009)$ \\
\hline \multirow[t]{2}{*}{ Intangible Assets } & 0.093 & 0.044 \\
\hline & $(0.069)$ & $(0.075)$ \\
\hline \multirow[t]{2}{*}{ Credit Rating } & 0.005 & 0.044 \\
\hline & $(0.056)$ & $(0.062)$ \\
\hline \multirow[t]{2}{*}{ Age of the Owner } & $0.022 * *$ & 0.013 \\
\hline & $(0.009)$ & $(0.010)$ \\
\hline \multirow[t]{2}{*}{ Work Experience } & -0.008 & -0.011 \\
\hline & $(0.010)$ & $(0.011)$ \\
\hline \multirow[t]{2}{*}{ Constant } & $-1.729 * * *$ & $-1.349 * * *$ \\
\hline & $(0.406)$ & $(0.438)$ \\
\hline Observations & 1,136 & 930 \\
\hline Number of Firms & 344 & 283 \\
\hline
\end{tabular}

Standard Errors are reported in parentheses. ${ }^{* * *}, * *, *$ denote variables statistically significant at the 1,5 and $10 \%$ level respectively

Table 1.6 Correlation between Employee Well-being \& Innovation

$\begin{array}{lcc}\text { Correlation A } & 2004 \text { Employee Wellbeing * 2005 Innovation } & 0.068 \\ \text { Correlation B } & 2004 \text { Innovation * 2005 Employee Wellbeing } & 0.066\end{array}$


Further, exploring the second variable in the three tier linkage, my study reports a negative impact of leverage on the level of innovation, a result that is contradictory to the result documented by Smith (2010), using the Kauffman Firm Survey. In my study, debt does not act as leverage in the debt-equity ratio. It is a known fact that with a moderate amount of equity in the capital mix, debt acts as a leverage device, and investments with external borrowings amplifies the firm's return to equity. A careful perusal of Figures 1.4, 1.5 and 1.6 shows that the level of total debt is varying over time and total equity shows a declining trend. In this study, an increase in leverage is coming from the decline in equity, and not from an increase in debt.

To have a full advantage of external borrowings, there should be a steady supply of funds. One of the reasons for changing debt levels in the survey is the denial of loan applications. Firms started with a mean debt level of $\$ 80,000$ in 2004 . However, of those firms that applied for new credit, or renewed their existing credit in 2008, approximately one-third had their applications denied. The most common reason cited for denial was insufficient collateral and poor credit history (Robb et al., 2010). Despite the varying level of debt, it remains the primary source of financing for all firms in this study (Brav, 2009; Heaton \& Lucas, 2001).

The financial crisis in 2007 affected the owner's confidence in the business. In 2008, owners were asked to report the effect of the financial meltdown on their businesses. The KFS reports that, out of the surviving sample, only $21 \%$ of the firms said they were unaffected by the financial crisis, while the remaining $40 \%$ reported somewhat affected, and $39 \%$ of them reported they were affected to a great extent (see Table 1.7). Owners were also asked to report the most challenging problem they faced in the past 
year, and almost $53 \%$ of the firms reported slow or lost sales (Robb et al., 2010). Consequently, the two main components of equity, owner's share of investment, and equity from the non-owner operators declined.

Table 1.7 Effect of Recent Financial Problems on the Firms

\begin{tabular}{cc}
\hline Description & Percentage of Surviving Firms \\
A lot & $39.0 \%$ \\
Some & $40.0 \%$ \\
Not at all & $21.0 \%$ \\
\hline
\end{tabular}

Source: KFS Microdata. Sample includes only surviving firms (2,606), Robb et al., (2010)

Analyzing the owner-specific variable, age of the owner positively affects the level of innovation. However, the result is not significant for the high-technology firms. One reason could be that high-technology industries are "new-age" industries, and an entrepreneur's age might be relevant in case of managerial knowledge, and may not be a determinant of technical knowledge.

Holmstrom (1989) suggests that firms that are concerned about their performance and reputation will not undertake risky projects. An expected adverse impact on credit ranking may motivate a firm to stay away from those projects that have higher levels of risk involved. Undertaking projects with high uncertainty can have a negative impact on innovation in the long run. However, in this sample, credit ratings do not explain the level of innovation.

Further, the linkage between the debt-equity ratio and employee well-being is analyzed using the fixed effects. Results are presented in Table 1.8 and report no significant relation between leverage and employee well-being. Theory of reducing debt 
in order to save employees from bankruptcy cost is not valid in this study. Further, total assets positively affect the leverage, whereas this result is not seen for high-technology firms. A large asset base helps a company in taking more loans, because these assets can act as collateral.

Table 1.8 Regression Results for Leverage with Fixed Effects

\begin{tabular}{lcc}
\hline \multicolumn{1}{c}{ Dependent Variable } & \multicolumn{2}{c}{ Debt - Equity Ratio } \\
\hline VARIABLES & All Firms & High-tech Firms \\
Employee Well Being & 0.002 & 0.001 \\
& $(0.003)$ & $(0.004)$ \\
Total Assets & $5.63 \mathrm{e}-0^{*}$ & $3.18 \mathrm{e}-0$ \\
& $(3.03 \mathrm{e}-08)$ & $(3.64 \mathrm{e}-08)$ \\
Size & $-0.003^{*}$ & $-0.005^{* * *}$ \\
& $(0.002)$ & $(0.002)$ \\
Intangible Assets & 0.012 & 0.013 \\
& $(0.015)$ & $(0.018)$ \\
Credit Rating & -0.002 & -0.007 \\
& $(0.008)$ & $(0.010)$ \\
Age of the Owner & $0.031^{* * *}$ & $0.031^{* * *}$ \\
& $(0.004)$ & $(0.005)$ \\
Constant & $-1.023^{* * *}$ & $-1.062^{* * *}$ \\
Observations & $(0.190)$ & $(0.231)$ \\
R-squared & 6,587 & 4,577 \\
Number of Firms & 0.020 & 0.022 \\
\hline
\end{tabular}

Standard Errors are reported in parentheses. ***, **, * denote variables statistically significant at the 1, 5 and $10 \%$ level respectively 


\subsection{Conclusion}

The present paper empirically examines the role of leverage and employee wellbeing on firm's innovation. Results document a negative impact of leverage on innovation. Changing levels of debt does not allow a firm to exploit the inherent benefits of using debt as leverage in the capital-mix. Fixed cost of debt financing affects the capital structure, which in turn generates a large impact in the variability of cash-flows to the shareholders.

The sample in the study consists of young firms, and demand for funds is limited by the capital constraints imposed by the lenders. These credit constraints lead to a disrupted supply of funds. It should be noted that innovation involves research activities that require a regular supply of funds. The current economic situation has led to a decrease in owner's equity, where owners are not willing to invest their own money into the business. A steady decline in equity will lead to a situation where these firms will become "all-debt" firms. In that scenario, leverage will lose its significance, and firms will have to bear fixed obligations in the form of interest payments, which will make the existing equity more risky. Use of debt allows a firm to enjoy the benefits from interest in the form of tax shield. With declining levels of equity, the additional value of the interest tax shield will be offset by an increase in the expected bankruptcy cost. This will further increase the probability of bankruptcy, and expected costs associated with it.

The asymmetry of information between lenders and borrowers is the major cause of capital constraints for young firms. It is interesting to observe that total debt for hightech firms showed a declining pattern only in the second year. This points towards the need for more mature financial markets that are ready to lend to business start-ups. 
Smaller banks can play a role in having "relationship lending" to young firms who have shown a good repayment track.

The study also presents a new perspective on human resource policies of the startups. Much of our knowledge on employee welfare activities is restricted to large and established firms. The study highlights that, in addition to the financial structure, young firms even care about the welfare of its employees. And this employee welfare reflects positively on the level of innovation. In other words, it is not only the large firms that formulate policies for employee well-being; even start-ups consider employee welfare as a part of the corporate structure. 


\section{Chapter 2: Speed of Entrepreneurial Learning and Firm Growth}

\section{$2.1 \quad$ Introduction}

Researchers have shown that there is evidence of an entrepreneur learning the tricks of the trade as time passes. Efficient entrepreneurs identify the opportunities offered by the market, which gets reflected in the growth of the business. Therefore, it becomes crucial to identify how fast an entrepreneur learns and adjusts his beliefs to the new information and signals received from the environment, and if an entrepreneur learns faster, does he generate better results for the business? If these newer beliefs do not bring any advantage to the organization, then why should an entrepreneur update his opinion on the basis of new signals? These questions are unraveled by building on the model of entrepreneurial learning developed by Parker (2006). The present study investigates, whether the speed of entrepreneurial learning is the same across time and across groups, and whether the firm's growth is altered by this learning. While the focus of the study is on capturing the speed of learning, it also explores the linkages between learning, growth and firm survival.

Parker (2006), using an adaptive expectations approach, finds that entrepreneurs assign more weight to the prior beliefs, and provides evidence of differences in speed of learning across groups. However, he treats the speed of learning as a constant, and presents little evidence on how the speed of learning evolves with the age of the firm. In contrast, the current study using a Bayesian framework presents theoretical evidence of a decline in the speed of learning, which is also in consonance with the empirical findings. 
Parker seeks to determine the speed of entrepreneurial learning captured through a change in effort level expended in the business. Using an adaptive expectations approach, he builds a model of entrepreneurial learning where an entrepreneur supplies effort, and forms an expectation of his effort's unobserved productivity for the next period. The entrepreneur only receives noisy signals about the productivity, so learning takes time. The reason for this is that outcomes associated with the effort are known to an entrepreneur only at the end of the period. Therefore an entrepreneur can only form an expectation about the productivity that his level of effort generates. The current effort and expectation of unobserved productivity together gets translated into a firm's earnings.

Further, Parker's model suggests that an entrepreneur's future actions are derived from the asymmetry between the expectations he formed in the previous period, and the market signals he receives in the real time. If there is no divergence between the expectations and the noisy signals, he maintains the status quo. However, if the expectations formed exceed the signals, he will update his beliefs about the unobserved productivity, and decrease the effort supplied in the next period. In contrast, if signals are greater than the expectations, he will update the unobserved productivity in a way that will increase the future work effort. The new effort level will further affect the earnings in the next period. The continuous updating process in the light of new information captures the speed with which an entrepreneur responds to the newer signals. Therefore, future prospects depend on how effectively an entrepreneur processes new, volatile, and costly signals that he receives from the environment (Casson, 2005). Levinthal (1996) mentions that adaptive exchange with the environment changes the behavior of an entrepreneur that further leads to "specialization" (p.26-27). The methodology of 
adaptive expectations even allows for arbitrary choices which are updated on the basis of the signals an entrepreneur receives (Marcet \& Nicolini, 2003; Milani, 2007; Politis, 2005).

Parker uses weekly hours expended into the business by an owner as a measure of work effort. He uses a two year data from the British Household Panel Survey, and finds that entrepreneurs adjust their beliefs by $16 \%$ when they receive new signals. He refers to this process of adjusting beleifs as, "the extent to which entrepreneurs exploit new information when updating their expectations" (p.7). In other words, entrepreneurs assign lesser weight to the newer information, and more to his older beliefs. He finds that there are no significant differences in the speed of learning between male and female entrepreneurs, or between employers and non-employer firms. However, he reports that younger entrepreneurs significantly assign a higher weight to the new signals as compared to the older entrepreneurs.

Parker treats the speed of learning (which he captures through $\lambda$, see section 2 for a detailed analysis) as a constant, which captures how an entrepreneur assigns weights between the past beliefs and the new signals. In his analysis, there is little evidence of how the speed of learning evolves over time. The weighing process, if analyzed over a longer period of time, will reveal how the mix of weights between new and prior beliefs evolve. To exactly capture this weighing trend empirically, six year confidential microdata provided by the KFS through the National Opinion Research Center (NORC) data enclave is used for the analysis. Following the methodology specified by Parker, learning speed is calculated using Ordinary Least Squares (OLS) in repeated cross-sections. For a six year data-set, five parameters depicting the speed are estimated. The study seeks to 
examine existence of a pattern between the weights over a period longer than two years. A clear declining trend is witnessed over the six years of analysis, where entrepreneurs assign lesser weight to the newer signals each year, and more to the prior beliefs.

The evidence in the study is in consonance with the set-up of Bayesian learning, where it is known that the speed of learning declines with the age of the firm. There is less information to extract from the noisy signals, which an entrepreneur receives as the business gets older. Bayesian learning formulates learning in a framework where an entrepreneur is not fully informed, and updates his beliefs using a Bayesian learning rule. The initial beliefs in the Bayesian learning are termed as "prior," which are revised contingent on the events that yields an updated or modified uncertainty known as "posterior." The whole process is known as "updating a prior" because the posterior in the current stage will act as a prior to the next stage (Albert, 2001, p.2). Linking the concept of posterior and prior to the present study, there is clear evidence that the posterior beliefs that an entrepreneur deciphers from an expectation of the unobserved productivity carry less weight each year. The declining weight leads to a decline in the speed of learning. So, as the firm gets older, less weight is assigned to the new information, and it suggests a Bayesian model rather than the adaptive expectations model written by Parker.

Further, it is not possible to test for the survivorship bias in Parker's study. It is possible that firms that survive a longer period display a higher speed of learning. To account for survivorship bias, the present study looks into two scenarios. In the first case, accounting for firm attrition, speed of learning is calculated for those firms that survived all six years. In the second case, the entire sample is considered. Pooled OLS estimator is 
used to calculate the differences in learning across the groups. Six categories are defined on the basis of individual-, market- and industry-specific factors. These are: gender, age, primary location of the business, whether the firm has employees, technology level, and legal status. Cross-section of firms displays a similar result under both the scenarios providing evidence for no survivorship bias.

One of the missing pieces from Parker's study is whether the speed of learning alters the firm's performance. If an entrepreneur is quick in imbibing the signals, and acts fast, it is of further interest to determine its impact on the firm's performance. Is there a clear one-to-one mapping of higher speed of learning to superior firm performance? Or, is the speed of learning just a response variable that only captures the volatility in the work effort, and has no relation to the firm's growth. Therefore, to test for a relation between the entrepreneurial speed of learning and the firm's growth, return on assets is calculated for the firms that survived all six years, and is compared with the speed of learning. The empirical results provide evidence of no clear linkage between the two variables. Firms with higher speed of learning are not necessarily high growth, or better performing firms.

The above result should be interpreted with caution because firms with slow speed of learning are the firms which perform better in terms of growth and survival. There is a clear linkage between survival rate and firm growth. Firms that survived the entire six year period show a higher rate of return on assets. A longer spell is favorable for the growth of the firms. The reason for this can be ascribed to the fact that, with the age, firm productivity level improves (Irwin \& Klenow, 1994). Better productivity gets translated into a higher growth rate. There is research exploring the intricate relation 
between firm age, survival and growth. While some studies point towards the fact that the relation between these factors vary across industries among start-ups (Dunne et al., 1989), some ascribe this to the ability of a firm to adapt to the ever-changing business environment (Geroski, 1995), and some have even pointed out that, "entrants that are able to survive exhibit higher growth rates" (Audretsch, 1995, p.1). These results are confirmed for the sample under consideration.

There are three implications from the above discussion. First, the speed of learning declines with time. The noisy signals carry less weight, and each set of new information is less important to the entrepreneur as compared to the old one. It should be noted that the firms in this data-set are start-ups, and are in their sixth year of existence. While there is more to learn in the initial years, the need to assign more weight to the market signals goes down when a business is firmly established. The above-mentioned fact is supported within the framework of Bayesian learning. An entrepreneur then relies on his past behavior to steer him towards the path of success. The analysis has some policy implications for the organizations that train and assist business start-ups. It is advisable to guide and assist the start-ups in the initial years when entrepreneurs are open to the concept of learning, and assign more weight to the market signals. Assistance in the form of policy programs does affect the venture performance (Roper \& Hart, 2005), because an entrepreneur's past and current beliefs are not processed in isolation. There is interdependency between these beliefs and actions that guide an entrepreneur, and builds his future beliefs (Minniti \& Bygrave, 2001).

Second, differentials in the speed of learning across groups do not suggest superiority of one group over another. In the present study, there is clear evidence of a 
significantly higher speed of learning for firms operating from the rental location as compared to the firms operating from home. Similarly, firms with employees, and firms that are established as corporations have a higher speed of learning. However, this does not imply that the firms with higher speed of learning are better than the comparison groups. Considering two cases, (i) let us assume that firms operating from home and rental spaces both share the same level of information to begin with, but firms in rental spaces have access to more precise current market signals than firms operating from home. It seems that firms in rental locations are better than the ones which operate from the home. However, firms operating from rental offices learn faster because the new information they receive is more precise, and they know more than the other group to begin with; (ii) let us assume that if firms operating from rental locations knows less to begin with, and both groups receive current market signals with the same precision, it can be inferred that firms in the rental location are not good performers. They show a higher speed of learning because they have more to learn in order to catch up to the level of firms operating from home. Therefore, a higher speed of learning is not necessarily a good thing. Even with a higher speed of learning, one group could be better or worse than the other. To gain evidence of the result from Bayesian learning, further analysis in this study explores the linkage between higher speed of learning, and firm growth that is explained in the next point.

Third, empirical analysis suggests that a higher speed of learning does not alter a firm's growth rate. It can be inferred that, even if an entrepreneur assigns more weight to the noisy market signals, it does not mean that this will be reflected in the firm's performance. It could be that each additional signal an entrepreneur receives is not worth 
the prior signal. This means that future signals are not as informative for the entrepreneur in the later stages, and therefore, does not get translated into the performance of the business. If group A shows a higher speed of learning as compared to group B, in this framework it would mean that entrepreneurs in group A assign a higher weight to the market signals as compared to group B. Furthermore, if growth rate for group B is greater than group A, this would simply mean that the prior beliefs held by group B entrepreneurs are more informative than the market signals that are received by group A.

The above perspective points towards the fact that the speed of learning tends to decline with the age of the firm. However, this learning does not modify a firm's growth. The decline in speed of learning should be interpreted with caution because assigning less weight to the newer signals does not imply that there is no learning. In fact, an entrepreneur with time learns to identify the relative worth of each signal, and assigns weights accordingly. Assigning less weight is in consonance with the fact that firm's with a slower speed of learning show a higher survival rate, and also a higher growth rate. Past beliefs formed over this updating process serve as an important referral point, and these beliefs are further reflected into higher survival and growth rate. Results are interpreted in the light of Bayesian framework rather than adaptive expectations approach adopted by Parker.

The remainder of this paper is organized as follows. Section 2.2 explains Parker's model of learning. Section 2.3 describes the data-set used for this study and how variables are constructed. Section 2.4 presents the empirical estimation of speed of learning across years and groups. It further presents evidence for results by interpreting 
them in light of Bayesian framework, followed by exploring the linkage between the speed of learning and the firm's growth. Section 2.5 presents the conclusion of the study.

\subsection{Entrepreneurial learning}

Accurate information on what affects a firm's performance and makes an entrepreneur successful is important in formulating policy programs. Accurate information is even more relevant in the case of business start-ups where it is tough to survive the initial years, and even tougher to achieve a respectable growth rate. The initial years of start-ups define future growth trajectory. An entrepreneur who can promptly identify the market signals in the initial years will be better equipped to recognize the opportunities, and deal with the macro-economic shocks. "Starting a new business is essentially an experiment...which can be tested by experience" (Block \& McMillan, 1985). The experimentation method leads to a process of learning and re-learning (Petkova, 2009), which improves the entrepreneur's repertoire of ready references to be used in the future when he faces similar situations. Therefore, history does matter (Arthur, 1989), but to what extent will an entrepreneur be willing to rely on his past while making current decisions? Factors that affect entrepreneurial learning are deemed important, yet they are poorly understood, leaving us uninformed about its empirical measurement. Using the adaptive expectations approach, Parker determines the speed of learning by capturing the weighing process followed by an entrepreneur, which is explained in the next sub-section.

\subsubsection{Parker's model of entrepreneurial learning}

Parker follows an adaptive expectations framework where an entrepreneur forms an expectation that is based on his past experience. An updating process changes these 
expectations over a period of time, correcting for the systematic forecasting error. In Parker's study, an entrepreneur supplies the effort that is captured through hours worked per week in the business, $h_{i t}$. Entrepreneur's ability, the market status, and a stochastic component determine his productivity level. The stochastic component makes the true productivity level indeterminable, which leaves an entrepreneur to form an expectation about the "unobserved productivity" in the next period. It should be noted that the earnings of the firm gets affected by this unobserved productivity via effort level supplied by an entrepreneur. Therefore, it becomes important to form correct expectations that help an owner to make apt judgments about the effort he is going to supply in the next period. This updating process captures the speed with which an entrepreneur changes his prior beliefs, and determines weight to be assigned to the noisy signals.

Considering the labor supply models, there is enough research in the area of hours expended by the employees, and its impact on their productivity (Blundell \& MaCurdy, 1999). The main issue in analyzing the work effort by the workers of a firm is to determine the wage bill to be disbursed. In case of owners, effort exerted has a broader impact not only on the firm's current performance, but also on its future growth. In this study, hours worked by an owner are used to construct an index of entrepreneurial learning.

In Parker's model, an entrepreneur $i$, tries to maximize a linear utility function $U\left(\Pi_{i t}, c_{i t}\right)$ at time $t$ :

$U=U\left(\Pi_{i t}, c_{i t}\right)=\Pi_{i t}-c_{i t}$, 
where, $\Pi_{i t}$, is the weekly net operating profit, and $c_{i t}$ is the non-pecuniary cost of effort supplied by the entrepreneur, which takes the form of a Stone-Geary convex cost function:

$c_{i t}=(2 \gamma)^{-1}\left(h_{i t-1}-\underline{H}\right)^{2}$,

where, $\gamma>0, \underline{H} \geq 0$ are both parameters, and entrepreneurs dislike working beyond $\underline{H}$. True unobserved productivity, $p_{i t}$, is defined as the ratio of output (current revenue) to input (effort exerted in the last period, i.e. lag hours, $h_{i t-I}$ ). Combining the signal of unobserved productivity and normalizing the output to one, productivity becomes, $\hat{p}_{i t}=\frac{1}{h_{i t-1}}$, and signal for revenue can be extracted as, $1=\hat{p}_{i t} \cdot h_{i t-1}$. Pecuniary operating costs take the form $\phi_{i t} \cdot h_{i t-1}$, where $\phi_{i t}$ is the marginal operating cost, and it consists of two parts, an individual specific marginal cost, $\phi_{i}$, and a stochastic component, $\varepsilon_{t}$. It is assumed that $\phi_{i}$ is known to an entrepreneur with certainty and $E\left(\varepsilon_{t}\right)=0$. Therefore, operating profits are

$\Pi_{i t}=\hat{p}_{i t} \cdot h_{i t-1}-\phi_{i t} \cdot h_{i t-1}$,

from which the signal, $\hat{p}_{i t}$, can be obtained:

$\hat{p}_{i t}=\frac{\Pi_{i t}}{h_{i t-1}}+\phi_{i t}$

To determine the effort to be exerted in the next period, an entrepreneur forms an expectation of his true unobserved productivity, $p_{i t}$, that is based on the information set, $\Omega_{i t}$, available to him at time $t$, and the signals an entrepreneur receives for his future unobserved productivity, $\hat{p}_{i t+1}$, as described in equation (4). This yields, 
$E\left(\hat{p}_{i t+1} \mid \Omega_{i t}\right)=E\left(p_{i t} \mid \Omega_{i t}\right)$.

The information set at time $t$, is the union of past information set available at time $t-1$, and the productivity signal at time $t$. The entrepreneur continuously interacts with his environment, and receives new signals about the effort he supplies. The interaction process helps him in updating his beliefs, which in part comes from the new signals, and in part from his prior beliefs. The updating process finally leads to learning about the true state of nature, if $\lambda>0$, leading to the following assumption:

$E\left(p_{i t} \mid \Omega_{i t}\right)=E\left(p_{i t-1} \mid \Omega_{i t-1}\right)+\lambda\left[\hat{p}_{i t}-E\left(p_{i t-1} \mid \Omega_{i t-1}\right)\right], \quad 0 \leq \lambda \leq 1$

where, $\lambda \in[0,1]$ in equation (6) is a parameter that captures the speed of learning, or as Parker terms it, "the extent to which entrepreneurs exploit new information when updating their expectations." Generally, an entrepreneur's expectation of the unobserved productivity in period $t-1, E\left(p_{i t-1} \mid \Omega_{i t-1}\right)$, and the signals that he receives from the market for his unobserved productivity in period $t, \hat{p}_{i t}$, will not be same. There is bound to be a difference between the two which is captured by $\lambda$ in equation (6).

In equation (6), if $\lambda=0$, then (6) reduces to $E\left(p_{i t} \mid \Omega_{i t}=E\left(p_{i t-1} \mid \Omega_{i t-1}\right)\right.$, which implies that the entrepreneur assigns all weight to his prior beliefs, and does not learn from the noisy market signals. If $\lambda=1$, then (6) reduces to $E\left(p_{i t} \mid \Omega_{i t}\right)=\hat{p}_{i t}$, which implies that the entrepreneur assigns all weight to the noisy market signals. In this updating process, one can get intermediate values of $\lambda$, which implies that an entrepreneur tries to create a mix between noisy signals, and the prior beliefs. The new expectation of true unobserved productivity from (6) further guides an entrepreneur to decide on his effort level to be supplied in the next period. If his expectation of returns in the form of 
earnings has increased, he will exert more effort in period $t+1$. The effort level that maximizes expected net revenue can be calculated as:

$h_{i t}=\gamma E\left(p_{i t} \mid \Omega_{i t}\right)-\gamma \phi_{i}+\underline{H}$,

As $\gamma>0$, there is a positive relation between the expected productivity and effort. Substituting the values of $E\left(p_{i t} \mid \Omega_{i t}\right)$ in the above equation generates the regression equation from which we can estimate $\lambda$ :

$$
h_{i t}=\alpha+(1-\lambda) h_{i t-1}+\gamma \lambda\left(\frac{\Pi_{i t}}{h_{i t-1}}\right)+\mu_{i t} .
$$

In equation (8), $h_{i t}$ is the hours worked in period $t, \alpha=\lambda \underline{H}$ and is a positive

constant, $\frac{\Pi_{i t}}{h_{i t-1}}$ is the profit to lagged hours ratio, and $\mu_{i t}$ is an error term with mean zero.

Following Parker, equation (8) is estimated in the repeated cross-sections for the entire sample, and then a group wise analysis is conducted where lag hours and profit to lag hour ratio is interacted with a dummy variable. This dummy variable indicates membership of specific firm into the group or otherwise. The next section describes the data and how the variables are constructed.

\subsection{Sample Description}

\subsubsection{Data-set}

The study uses a confidential micro-dataset provided by the KFS through the NORC data enclave. To only include permanent failure, 2,082 firms are taken out from the sample because (i) they temporarily went out of business, (ii) of non-response/refusal, 
(iii) they were merged with another business or sold, or (iv) they had missing data on owners and revenue. The final sample size used in this study consists of 3,061 firms ${ }^{11}$.

\subsubsection{Variable construction}

Effort exerted by an entrepreneur is defined as, $h_{i t}$, hours worked per week at the business. To calculate the weekly net operating profit, $\Pi_{i t}$, annual net operating profit reported in the survey is divided by fifty two. To calculate the differences in learning between groups, six groups are defined on the basis of individual-, market- and industryspecific factors. These are: gender, age, primary location of business, whether the firm has employees, technology level, and legal status. Table 2.1 gives a detailed description of the groups.

\subsubsection{Owner-specific categorization}

Learning differentials are recorded for male and female entrepreneurs with the help of first categorization. In the baseline survey of 2004, approximately $69 \%$ of the firms have male owners, and the same trend is recorded in $2008(68 \%)$. However, in the constructed sample, firms with male entrepreneurs have a slightly higher survival rate.

Similarly, one of the important facets that affect the speed of learning is the age of an entrepreneur. With a modal age of 41 , entrepreneurs older than 41 are categorized as "older" and if the age is less than 41, they are categorized as "younger." In the case of older entrepreneurs, past behavior can act as a ready reference, whereas in the case of younger entrepreneurs where there is a lack of ready set of references, it is more likely that they will assign a higher weight to the current market signals. Therefore, it is

\footnotetext{
${ }^{11}$ For details on survey construction, see Chapter 1, section1.3.2.4
} 
interesting to measure the differences in the learning parameter for younger and older entrepreneurs.

\section{Table 2.1 Description of Sub-Groups}

\begin{tabular}{|c|c|c|}
\hline Sub-group & Categorization & Description \\
\hline \multicolumn{3}{|l|}{ Owner Specific } \\
\hline Gender of the Owner & $\begin{array}{l}\text { Female }=1 \\
\text { Male }=0\end{array}$ & Female being the reference group \\
\hline Age of the Owner & $\begin{array}{l}\text { Older }=1 \\
\text { Younger }=0\end{array}$ & Age $>41:$ Older (modal age) \\
\hline \multicolumn{3}{|l|}{ Firm Specific } \\
\hline Employer & $\begin{array}{l}\text { Employer }=1 \\
\text { Non Employer }=0\end{array}$ & Firm is an employer or not \\
\hline Location of business & $\begin{array}{l}\text { Home-Based=1 } \\
\text { Rented=2 } \\
\text { Other- Location=3 }\end{array}$ & $\begin{array}{l}\text { Describes location of the business } \\
\text { space }\end{array}$ \\
\hline Legal status & $\begin{array}{l}\text { Sole-Proprietor=1 } \\
\text { Corporation=2 } \\
\text { Other Legal=3 }\end{array}$ & Defines Legal status of the firm \\
\hline \multicolumn{3}{|l|}{ Industry Specific } \\
\hline Technology Level & $\begin{array}{l}\text { Hi-tech=1 } \\
\text { Med-tech=2 } \\
\text { Low-tech=3 }\end{array}$ & Firm belongs to which Industry \\
\hline
\end{tabular}

\subsubsection{Firm specific categorization}

It is also interesting to observe the linkage between the location of primary businesses and hours expended. If an entrepreneur can operate from home, one can argue that he may put in less number of hours. In 2004, approximately $50 \%$ of the firms were home-located businesses. The number declined to $48.9 \%$ in 2007 , after some entrepreneurs moved their businesses from residential houses to a rented place or other location. The motivation of expanding the business and/or moving closer to customers could be guiding this move. 
Another interesting feature is whether a firm's "employer status" changes the way an entrepreneur reacts to the market signals. Similarly, the legal status of the firm might generate differences in the way entrepreneurs assign the weights to the prior beliefs and market signals. One of the reasons for the difference could be that firms established as corporations face a lot more legal obligations as compared to the firms operating as sole proprietorship, making them more alert about the rules and regulations, thereby assigning a higher weight on the market signals.

\subsubsection{Industry specific categorization}

The nature of the industry in which a firm operates also affects an entrepreneur's ability to learn. Generally, high-technology companies are considered to infuse more number of new technologies and products into the market, as compared to non-hightechnology sector firms. In other words, one can infer that entrepreneurs of hightechnology firms react faster than non-high technology firm entrepreneurs. However, one can also argue that firms that are not technology-oriented have a lot more to learn regarding the market, and update their level of technology. With oversampled hightechnology firms in the data, industries have been classified as high-, medium-, lowtechnology industries. The next section explains the empirical results across years and groups.

\subsection{Empirical Estimation}

\subsubsection{Estimation across years}

Equation (8) is estimated using OLS in repeated cross-sections that generates five values of $\lambda$, where each value is based on changes in hours worked over two contiguous 
years. Figure 2.1 and 2.2 shows the path of two $\lambda \mathrm{s}$, one for surviving firms, and another one for the entire sample of firms. It is evident that $\lambda$ follows a downward trend in both the cases, and there are minor differences between the paths of $\lambda$ for the two groups. It is inferred that over a period of time the speed of learning tends to decline. The value of $\lambda$ for the entire sample as shown in Figure 2.1 starts from $29.8 \%$ in the base year, and then declines to $25.2 \%$ in the second year; in the third and fourth years it decreases to $18.8 \%$ and $17.5 \%$, and has a value of $16.7 \%$ in the final year (see Table $2.2(\mathrm{a}, \mathrm{b}, \mathrm{c})$ ). Recognizing the survey nature of the data, survey commands have been used for the analysis, and therefore all the tables report linearized standard errors.

Figure 2.1 Speed of Learning for the Entire Sample

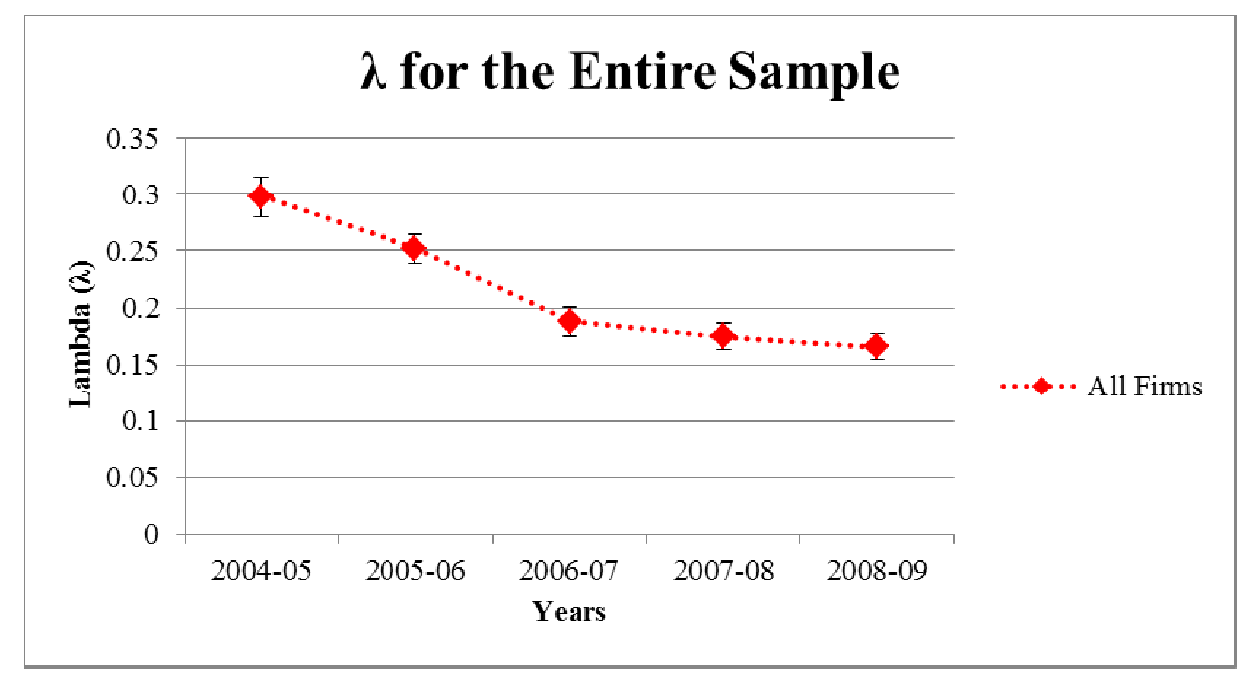


Figure 2.2 Speed of Learning for the Surviving Firms

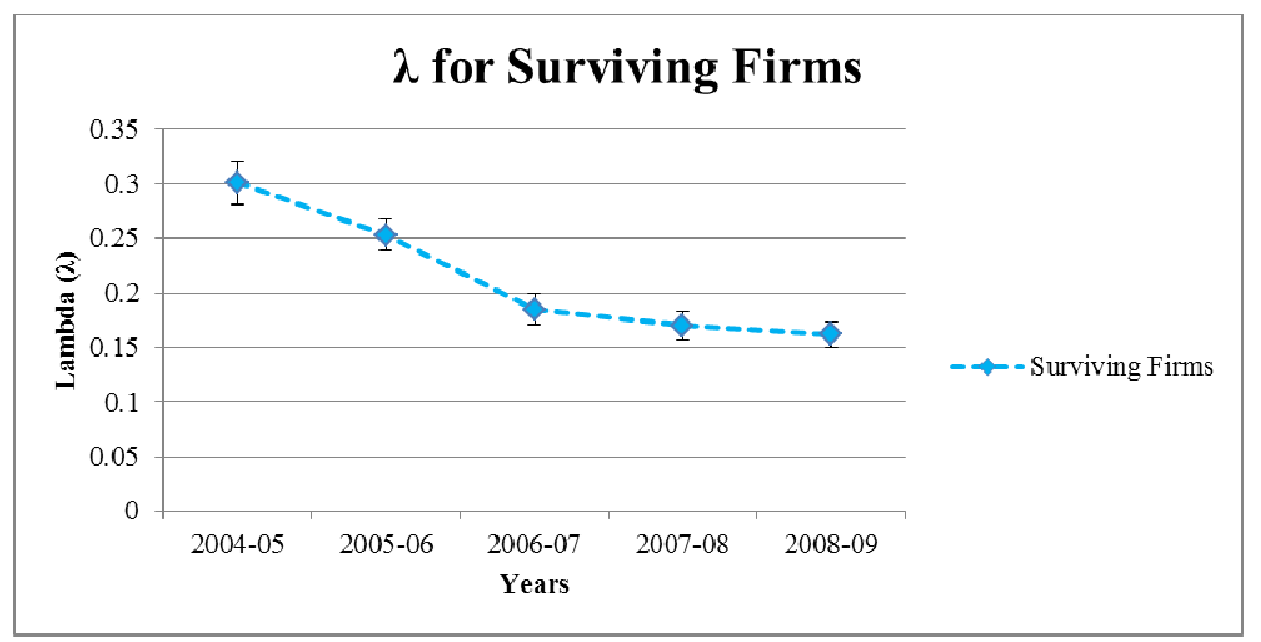

Table 2.2 (a) All firms: OLS - Pooled and Owner Specific

\begin{tabular}{|c|c|c|c|c|c|c|}
\hline Groups & 04-05 & 05-06 & 06-07 & 07-08 & 08-09 & $\begin{array}{c}\text { Significant } \\
\text { within groups } \\
\text { across years }\end{array}$ \\
\hline Pooled & $\begin{array}{c}0.29 * * * \\
(0.01)\end{array}$ & $\begin{array}{c}0.25 * * * \\
(0.01)\end{array}$ & $\begin{array}{c}0.18 * * * \\
(0.01)\end{array}$ & $\begin{array}{c}0.17 * * * \\
(0.01)\end{array}$ & $\begin{array}{c}0.16^{* * * *} \\
(0.01)\end{array}$ & - \\
\hline $\mathrm{R}^{2}$ & 0.57 & 0.61 & 0.66 & 0.67 & 0.68 & \\
\hline \multicolumn{7}{|c|}{ Owner Specific } \\
\hline Female & $\begin{array}{c}0.23 * * * \\
(0.03)\end{array}$ & $\begin{array}{c}0.23^{* * * *} \\
(0.02)\end{array}$ & $\begin{array}{c}0.22 * * * \\
(0.03)\end{array}$ & $\begin{array}{c}0.19 * * * \\
(0.02)\end{array}$ & $\begin{array}{c}0.16^{* * * *} \\
(0.02)\end{array}$ & \multirow{3}{*}{ No } \\
\hline Male & $\begin{array}{c}0.31^{* * * *} \\
(0.02)\end{array}$ & $\begin{array}{c}0.25^{* * *} \\
(0.01)\end{array}$ & $\begin{array}{c}0.17^{* * * *} \\
(0.01)\end{array}$ & $\begin{array}{c}0.17 * * * \\
(0.01)\end{array}$ & $\begin{array}{c}0.17 * * * \\
(0.01)\end{array}$ & \\
\hline $\mathrm{R}^{2}$ & 0.57 & 0.61 & 0.66 & 0.67 & 0.68 & \\
\hline Older & $\begin{array}{c}0.29 * * * \\
(0.02)\end{array}$ & $\begin{array}{c}0.23^{* * * *} \\
(0.01)\end{array}$ & $\begin{array}{c}0.17 * * * \\
(0.01)\end{array}$ & $\begin{array}{c}0.17 * * * \\
(0.01)\end{array}$ & $\begin{array}{c}0.15^{* * * *} \\
(0.01)\end{array}$ & \multirow{3}{*}{ No } \\
\hline Younger & $\begin{array}{c}0.32 * * * \\
(0.03)\end{array}$ & $\begin{array}{c}0.28^{* * * *} \\
(0.02)\end{array}$ & $\begin{array}{c}0.20^{* * *} \\
(0.02)\end{array}$ & $\begin{array}{c}0.18^{* * * *} \\
(0.02)\end{array}$ & $\begin{array}{c}0.19 * * * \\
(0.02)\end{array}$ & \\
\hline $\mathrm{R}^{2}$ & 0.57 & 0.61 & 0.66 & 0.67 & 0.68 & \\
\hline $\mathrm{N}$ & 1508 & 3061 & 2938 & 2719 & 2585 & \\
\hline
\end{tabular}

Significance of lambda for each group is tested using a Wald Test. Significance of lambda across years is tested using an Adjusted Wald test. ${ }^{*} \mathrm{p}<.10,{ }^{* *} \mathrm{p}<.05,{ }^{* * *} \mathrm{p}<.01$ 
Table 2.2 (b) All firms: OLS - Firm Specific

\begin{tabular}{|c|c|c|c|c|c|c|}
\hline Groups & 04-05 & 05-06 & 06-07 & 07-08 & 08-09 & $\begin{array}{l}\text { Significant within } \\
\text { groups across years }\end{array}$ \\
\hline Home Based & $\begin{array}{c}0.25 * * * \\
(0.02)\end{array}$ & $\begin{array}{c}0.22 * * * \\
(0.01)\end{array}$ & $\begin{array}{c}0.18^{* * * *} \\
(0.01)\end{array}$ & $\begin{array}{c}0.17^{* * *} \\
(0.01)\end{array}$ & $\begin{array}{c}0.16^{* * *} \\
(0.01)\end{array}$ & Yes $* * *$ \\
\hline $\mathrm{R}^{2}$ & 0.57 & 0.61 & 0.66 & 0.67 & 0.69 & \\
\hline Rented & $\begin{array}{c}0.46^{* * * *} \\
(0.03)\end{array}$ & $\begin{array}{c}0.37 * * * \\
(0.02)\end{array}$ & $\begin{array}{c}0.25^{* * *} \\
(0.02)\end{array}$ & $\begin{array}{c}0.22 * * * \\
(0.02)\end{array}$ & $\begin{array}{c}0.22 * * * \\
(0.03)\end{array}$ & Yes*** \\
\hline $\mathrm{R}^{2}$ & 0.58 & 0.62 & 0.66 & 0.67 & 0.69 & \\
\hline $\begin{array}{c}\text { Other } \\
\text { Location }\end{array}$ & $\begin{array}{c}0.22 * * * \\
(0.04)\end{array}$ & $\begin{array}{c}0.23^{* * * *} \\
(0.03)\end{array}$ & $\begin{array}{c}0.21 * * * \\
(0.03)\end{array}$ & $\begin{array}{c}0.19^{* * * *} \\
(0.03)\end{array}$ & $\begin{array}{c}0.18^{* * * *} \\
(0.02)\end{array}$ & No \\
\hline $\mathrm{R}^{2}$ & 0.57 & 0.61 & 0.66 & 0.67 & 0.68 & \\
\hline Employer & $\begin{array}{c}0.34 * * * \\
(0.02)\end{array}$ & $\begin{array}{c}0.29 * * * \\
(0.01)\end{array}$ & $\begin{array}{c}0.21 * * * \\
(0.01)\end{array}$ & $\begin{array}{c}0.21^{* * *} \\
(0.02)\end{array}$ & $\begin{array}{c}0.22 * * * \\
(0.02)\end{array}$ & \\
\hline $\begin{array}{c}\text { Non } \\
\text { Employer }\end{array}$ & $\begin{array}{c}0.24 * * * \\
(0.02)\end{array}$ & $\begin{array}{c}0.22 * * * \\
(0.02)\end{array}$ & $\begin{array}{c}0.18 * * * \\
(0.02)\end{array}$ & $\begin{array}{c}0.16^{* * *} \\
(0.01)\end{array}$ & $\begin{array}{c}0.15^{* * *} \\
(0.01)\end{array}$ & Yes*** \\
\hline $\mathrm{R}^{2}$ & 0.58 & 0.61 & 0.66 & 0.67 & 0.69 & \\
\hline Sole & $\begin{array}{c}0.26^{* * * *} \\
(0.02)\end{array}$ & $\begin{array}{c}0.24 * * * \\
(0.02)\end{array}$ & $\begin{array}{c}0.18^{* * *} \\
(0.03)\end{array}$ & $\begin{array}{c}0.17 * * * \\
(0.03)\end{array}$ & $\begin{array}{c}0.20 * * * \\
(0.02)\end{array}$ & No \\
\hline$R^{2}$ & 0.57 & 0.61 & 0.66 & 0.67 & 0.69 & \\
\hline Corporation & $\begin{array}{c}0.43^{* * * *} \\
(0.04)\end{array}$ & $\begin{array}{c}0.34 * * * \\
(0.03)\end{array}$ & $\begin{array}{c}0.25 * * * \\
(0.03)\end{array}$ & $\begin{array}{c}0.23 * * * \\
(0.03)\end{array}$ & $\begin{array}{c}0.18^{* * * *} \\
(0.02)\end{array}$ & Yes*** \\
\hline $\mathrm{R}^{2}$ & 0.58 & 0.61 & 0.66 & 0.67 & 0.69 & \\
\hline Other Legal & $\begin{array}{c}0.25^{* * * *} \\
(0.02)\end{array}$ & $\begin{array}{c}0.21^{* * * *} \\
(0.01)\end{array}$ & $\begin{array}{c}0.16^{* * * *} \\
(0.02)\end{array}$ & $\begin{array}{c}0.16^{* * *} \\
(0.02)\end{array}$ & $\begin{array}{c}0.15^{* * * *} \\
(0.02)\end{array}$ & No \\
\hline $\mathrm{R}^{2}$ & 0.57 & 0.61 & 0.66 & 0.67 & 0.69 & \\
\hline $\mathrm{N}$ & 1508 & 3061 & 2938 & 2719 & 2585 & \\
\hline
\end{tabular}

Significance of lambda for each group is tested using a Wald Test. Significance of lambda across years is tested using an Adjusted Wald test.* $\mathrm{p}<.10,{ }^{* *} \mathrm{p}<.05, * * * \mathrm{p}<.01$ 
Table 2.2 (c) All firms: OLS - Industry Specific

\begin{tabular}{|c|c|c|c|c|c|c|}
\hline Groups & 04-05 & 05-06 & 06-07 & 07-08 & 08-09 & $\begin{array}{l}\text { Significant within } \\
\text { groups across years }\end{array}$ \\
\hline Hi-tech & $\begin{array}{c}0.27 * * * \\
(0.04)\end{array}$ & $\begin{array}{c}0.26^{* * * *} \\
(0.03)\end{array}$ & $\begin{array}{c}0.23 * * * \\
(0.03)\end{array}$ & $\begin{array}{c}0.18^{* * *} \\
(0.03)\end{array}$ & $\begin{array}{c}0.15^{* * * *} \\
(0.03)\end{array}$ & No \\
\hline $\mathrm{R}^{2}$ & 0.57 & 0.61 & 0.66 & 0.67 & 0.68 & \\
\hline Med-tech & $\begin{array}{c}0.28 * * * \\
(0.03)\end{array}$ & $\begin{array}{c}0.24^{* * *} \\
(0.02)\end{array}$ & $\begin{array}{c}0.21 * * * \\
(0.02)\end{array}$ & $\begin{array}{c}0.18^{* * *} \\
(0.02)\end{array}$ & $\begin{array}{c}0.14^{* * * *} \\
(0.01)\end{array}$ & No \\
\hline $\mathrm{R}^{2}$ & 0.57 & 0.61 & 0.66 & 0.67 & 0.68 & \\
\hline Low-tech & $\begin{array}{c}0.31 * * * \\
(0.02)\end{array}$ & $\begin{array}{c}0.25^{* * *} \\
(0.01)\end{array}$ & $\begin{array}{c}0.16^{* * *} \\
(0.01)\end{array}$ & $\begin{array}{c}0.17 * * * \\
(0.01)\end{array}$ & $\begin{array}{c}0.18^{* * * *} \\
(0.01)\end{array}$ & No \\
\hline $\mathrm{R}^{2}$ & 0.57 & 0.61 & 0.66 & 0.67 & 0.68 & \\
\hline $\mathrm{N}$ & 1508 & 3061 & 2938 & 2719 & 2585 & \\
\hline
\end{tabular}

Significance of lambda for each group is tested using a Wald Test. Significance of lambda across years is tested using an Adjusted Wald test.* $\mathrm{p}<.10,{ }^{* *} \mathrm{p}<.05, * * * \mathrm{p}<.01$ 
Figure 2.3 Comparison Based on Groups ${ }^{12}$
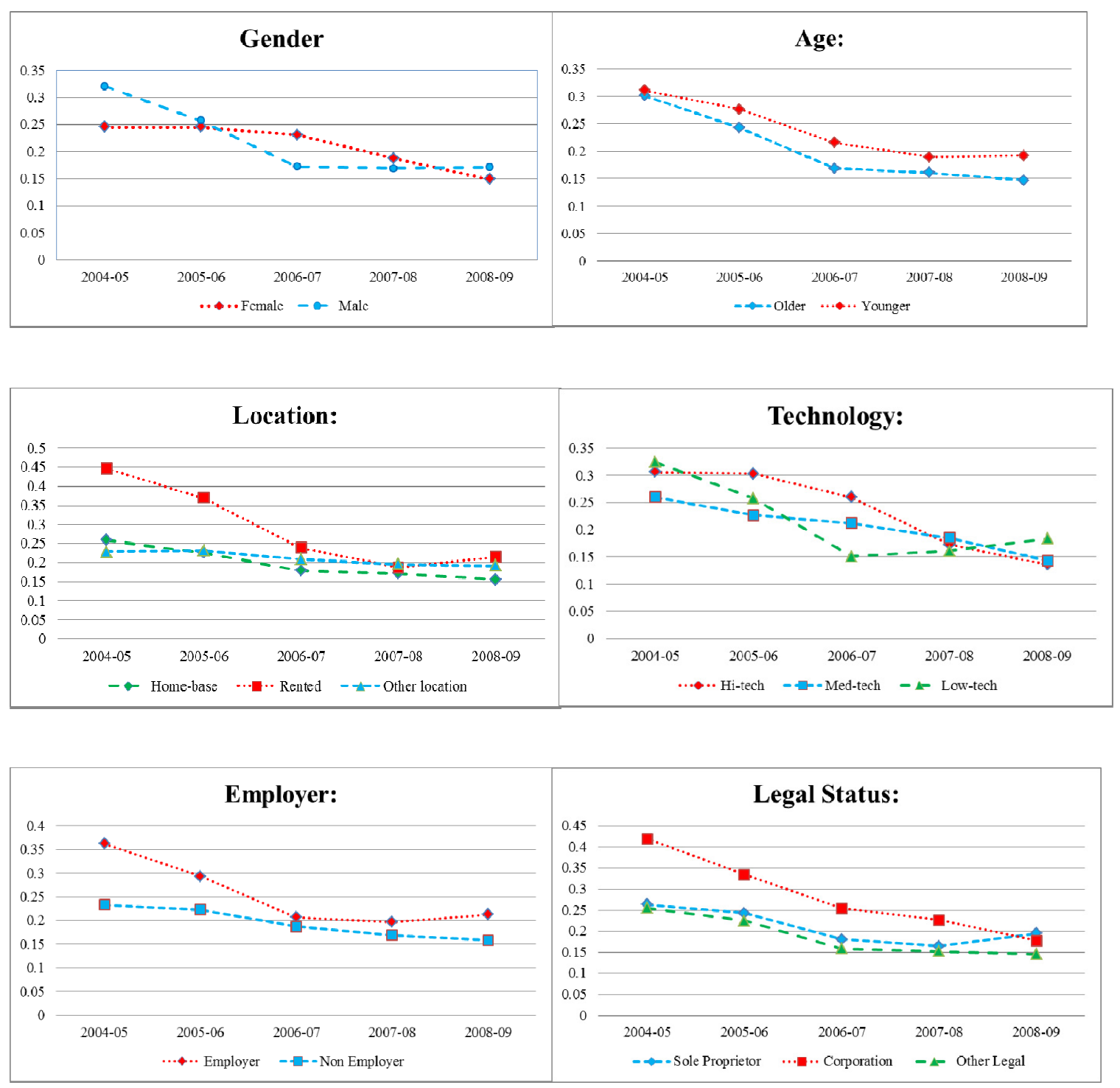

${ }^{12}$ Lambda, the speed of learning is captured on $\mathrm{Y}$-axis, and Years are represented on $\mathrm{X}$-axis. 
Table 2.3 (a) Surviving firms: OLS - Pooled and Owner Specific

\begin{tabular}{|c|c|c|c|c|c|c|}
\hline Groups & 04-05 & 05-06 & 06-07 & 07-08 & 08-09 & $\begin{array}{l}\text { Significant within } \\
\text { groups across years }\end{array}$ \\
\hline Pooled & $\begin{array}{c}0.30 * * * \\
(0.02)\end{array}$ & $\begin{array}{c}0.25 * * * \\
(0.01)\end{array}$ & $\begin{array}{c}0.18 * * * \\
(0.01)\end{array}$ & $\begin{array}{c}0.17 * * * \\
(0.01)\end{array}$ & $\begin{array}{c}0.16 * * * \\
(0.01)\end{array}$ & - \\
\hline $\mathrm{R}^{2}$ & 0.57 & 0.61 & 0.67 & 0.68 & 0.68 & \\
\hline \multicolumn{7}{|c|}{ Owner Specific } \\
\hline Female & $\begin{array}{c}0.24 * * * \\
(0.03)\end{array}$ & $\begin{array}{c}0.24 * * * \\
(0.03)\end{array}$ & $\begin{array}{c}0.23 * * * \\
(0.03)\end{array}$ & $\begin{array}{c}0.18 * * * \\
(0.03)\end{array}$ & $\begin{array}{c}0.14 * * * \\
(0.02)\end{array}$ & \\
\hline Male & $\begin{array}{c}0.31 * * * \\
(0.02)\end{array}$ & $\begin{array}{c}0.25 * * * \\
(0.01)\end{array}$ & $\begin{array}{c}0.17 * * * \\
(0.01)\end{array}$ & $\begin{array}{c}0.17 * * * \\
(0.01)\end{array}$ & $\begin{array}{c}0.17 * * * \\
(0.01)\end{array}$ & No \\
\hline $\mathrm{R}^{2}$ & 0.57 & 0.61 & 0.67 & 0.68 & 0.69 & \\
\hline Older & $\begin{array}{c}0.30 * * * \\
(0.02)\end{array}$ & $\begin{array}{c}0.24 * * * \\
(0.01)\end{array}$ & $\begin{array}{c}0.16 * * * \\
(0.01)\end{array}$ & $\begin{array}{c}0.16 * * * \\
(0.01)\end{array}$ & $\begin{array}{c}0.14 * * * \\
(0.01)\end{array}$ & \\
\hline Younger & $\begin{array}{c}0.31 * * * \\
(0.03)\end{array}$ & $\begin{array}{c}0.27 * * * \\
(0.02)\end{array}$ & $\begin{array}{c}0.21 * * * \\
(0.02)\end{array}$ & $\begin{array}{c}0.19 * * * \\
(0.02)\end{array}$ & $\begin{array}{c}0.19 * * * \\
(0.02)\end{array}$ & No \\
\hline $\mathrm{R}^{2}$ & 0.57 & 0.61 & 0.67 & 0.68 & 0.68 & \\
\hline $\mathrm{N}$ & 1295 & 2661 & 2617 & 2448 & 2432 & \\
\hline
\end{tabular}

Significance of lambda for each group is tested using a Wald Test. Significance of lambda across years is tested using an Adjusted Wald test. ${ }^{*} \mathrm{p}<.10,{ }^{* *} \mathrm{p}<.05,{ }^{* * *} \mathrm{p}<.01$ 
Table 2.3 (b) Surviving firms: OLS - Firm Specific

\begin{tabular}{|c|c|c|c|c|c|c|}
\hline Groups & 04-05 & 05-06 & 06-07 & 07-08 & 08-09 & $\begin{array}{l}\text { Significant within } \\
\text { groups across years }\end{array}$ \\
\hline $\begin{array}{l}\text { Home } \\
\text { Based }\end{array}$ & $\begin{array}{c}0.25 * * * \\
(0.02)\end{array}$ & $\begin{array}{c}0.22 * * * \\
(0.02)\end{array}$ & $\begin{array}{c}0.17 * * * \\
(0.02)\end{array}$ & $\begin{array}{c}0.17 * * * \\
(0.01)\end{array}$ & $\begin{array}{c}0.15 * * * \\
(0.01)\end{array}$ & Yes $* * *$ \\
\hline $\mathrm{R}^{2}$ & 0.57 & 0.62 & 0.67 & 0.68 & 0.68 & \\
\hline Rented & $\begin{array}{c}0.44 * * * \\
(0.03)\end{array}$ & $\begin{array}{c}0.36^{* * * *} \\
(0.02)\end{array}$ & $\begin{array}{c}0.23 * * * \\
(0.02)\end{array}$ & $\begin{array}{c}0.18^{* * * *} \\
(0.02)\end{array}$ & $\begin{array}{c}0.21 * * * \\
(0.03)\end{array}$ & Yes*** \\
\hline $\mathrm{R}^{2}$ & 0.58 & 0.62 & 0.67 & 0.68 & 0.68 & \\
\hline $\begin{array}{c}\text { Other } \\
\text { Location }\end{array}$ & $\begin{array}{c}0.22 * * * \\
(0.05)\end{array}$ & $\begin{array}{c}0.23 * * * \\
(0.03)\end{array}$ & $\begin{array}{c}0.20^{* * *} \\
(0.03)\end{array}$ & $\begin{array}{c}0.19^{* * *} \\
(0.03)\end{array}$ & $\begin{array}{c}0.19 * * * \\
(0.03)\end{array}$ & Yes*** \\
\hline $\mathrm{R}^{2}$ & 0.57 & 0.61 & 0.67 & 0.68 & 0.68 & \\
\hline Employer & $\begin{array}{c}0.36^{* * * *} \\
(0.02)\end{array}$ & $\begin{array}{c}0.29 * * * \\
(0.01)\end{array}$ & $\begin{array}{c}0.20^{* * *} \\
(0.01)\end{array}$ & $\begin{array}{c}0.19^{* * * *} \\
(0.02)\end{array}$ & $\begin{array}{c}0.21 * * * \\
(0.02)\end{array}$ & \\
\hline $\begin{array}{l}\text { Non } \\
\text { Employer }\end{array}$ & $\begin{array}{c}0.23 * * * \\
(0.03)\end{array}$ & $\begin{array}{c}0.22 * * * \\
(0.02)\end{array}$ & $\begin{array}{c}0.18^{* * *} \\
(0.02)\end{array}$ & $\begin{array}{c}0.16^{* * *} \\
(0.02)\end{array}$ & $\begin{array}{c}0.15 * * * \\
(0.01)\end{array}$ & Yes \\
\hline $\mathrm{R}^{2}$ & 0.58 & 0.62 & 0.67 & 0.68 & 0.69 & \\
\hline $\begin{array}{c}\text { Sole } \\
\text { Proprietor }\end{array}$ & $\begin{array}{c}0.26^{* * * *} \\
(0.30)\end{array}$ & $\begin{array}{c}0.24 * * * \\
(0.02)\end{array}$ & $\begin{array}{c}0.18^{* * * *} \\
(0.02)\end{array}$ & $\begin{array}{c}0.16^{* * * *} \\
(0.02)\end{array}$ & $\begin{array}{c}0.19 * * * \\
(0.02)\end{array}$ & No \\
\hline $\mathrm{R}^{2}$ & 0.57 & 0.61 & 0.67 & 0.68 & 0.68 & \\
\hline Corporation & $\begin{array}{c}0.42 * * * \\
(0.04)\end{array}$ & $\begin{array}{c}0.33 * * * \\
(0.03)\end{array}$ & $\begin{array}{c}0.25^{* * * *} \\
(0.02)\end{array}$ & $\begin{array}{c}0.22 * * * \\
(0.03)\end{array}$ & $\begin{array}{c}0.17 * * * \\
(0.02)\end{array}$ & Yes*** \\
\hline $\mathrm{R}^{2}$ & 0.58 & 0.61 & 0.66 & 0.67 & 0.69 & \\
\hline Other Legal & $\begin{array}{c}0.25 * * * \\
(0.03)\end{array}$ & $\begin{array}{c}0.22 * * * \\
(0.02)\end{array}$ & $\begin{array}{c}0.15^{* * * *} \\
(0.02)\end{array}$ & $\begin{array}{c}0.15^{* * * *} \\
(0.02)\end{array}$ & $\begin{array}{c}0.14 * * * \\
(0.01)\end{array}$ & No \\
\hline $\mathrm{R}^{2}$ & 0.57 & 0.61 & 0.67 & 0.68 & 0.68 & \\
\hline $\mathrm{N}$ & 1295 & 2661 & 2617 & 2448 & 2432 & \\
\hline
\end{tabular}

Significance of lambda for each group is tested using a Wald Test. Significance of lambda across years is tested using an Adjusted Wald test.* $\mathrm{p}<.10,{ }^{* *} \mathrm{p}<.05,{ }^{* * *} \mathrm{p}<.01$ 
Table 2.3 (c) Surviving firms: OLS - Industry Specific

\begin{tabular}{|c|c|c|c|c|c|c|}
\hline Groups & $\mathbf{0 4 - 0 5}$ & $\mathbf{0 5 - 0 6}$ & $\mathbf{0 6 - 0 7}$ & $\mathbf{0 7 - 0 8}$ & $\mathbf{0 8 - 0 9}$ & $\begin{array}{c}\text { Significant within } \\
\text { groups across years }\end{array}$ \\
\hline Hi-tech & $\begin{array}{c}0.30^{* * *} \\
(0.05)\end{array}$ & $\begin{array}{c}0.30^{* * *} \\
(0.04)\end{array}$ & $\begin{array}{c}0.26^{* * *} \\
(0.03)\end{array}$ & $\begin{array}{c}0.17^{* * *} \\
(0.03)\end{array}$ & $\begin{array}{c}0.13^{* * *} \\
(0.03)\end{array}$ & No \\
$\mathrm{R}^{2}$ & 0.57 & 0.61 & 0.67 & 0.68 & 0.68 & No \\
\hline Med-tech & $\begin{array}{c}0.26^{* * *} \\
(0.03)\end{array}$ & $\begin{array}{c}0.22^{* * *} \\
(0.02)\end{array}$ & $\begin{array}{c}0.21^{* * *} \\
(0.02)\end{array}$ & $\begin{array}{c}0.18^{* * *} \\
(0.02)\end{array}$ & $\begin{array}{c}0.14^{* * *} \\
(0.02)\end{array}$ & \\
$\mathrm{R}^{2}$ & 0.57 & 0.61 & 0.67 & 0.68 & 0.68 & Yes*** \\
\hline Low-tech & $0.32^{* * *}$ & $0.25^{* * *}$ & $0.15^{* * *}$ & $0.16^{* * *}$ & $0.18^{* * *}$ & $(0.01)$ \\
$\mathrm{R}^{2}$ & $(0.02)$ & $(0.01)$ & $(0.01)$ & $(0.01)$ & 0.68 & \\
\hline $\mathrm{N}$ & 0.57 & 0.61 & 0.67 & 0.68 & 0.68 & \\
\hline
\end{tabular}

Significance of lambda for each group is tested using a Wald Test. Significance of lambda across years is tested using an Adjusted Wald test.* $\mathrm{p}<.10,{ }^{* *} \mathrm{p}<.05,{ }^{* * *} \mathrm{p}<.01$

It is interesting to observe that Parker estimated $\lambda$ to be $16 \%$ from a single crosssection and firms with differing ages, suggesting that there is a little impact of newer information on entrepreneurs. In the initial years of a firm's existence, there is a plethora of new information to be absorbed and assimilated by an entrepreneur that yields the maximum learning. As time elapses and an entrepreneur is fine tuned to the demands and expectations of the business, additional learning tends to decline. Therefore, beliefs that affect the learning process may either lose or gain their influence over time (Bullard \& Duffy, 1994; Dawid, 1999; Minniti \& Bygrave, 2001).

Table $2.2(a, b, c)$ gives a detail account of variation in $\lambda$ over six years for the entire sample, and Table $2.3(a, b, c)$ lists the values of $\lambda$ for the firms which survived six years. These results are presented over owner-, firm- and industry-specific groups, and the same declining trend is observed (also see Figure 2.3). The value of $\lambda$ is significant at 
$1 \%$ level in each year. Further $\lambda$ s are tested for significance across years using a Wald test and found to be significant.

Table $2.2(\mathrm{a}, \mathrm{b}, \mathrm{c})$ and $2.3(\mathrm{a}, \mathrm{b}, \mathrm{c})$ provide the year-specific results. To analyze how different groups react to the market signals and alter their speed of learning, a pooled OLS estimator is calculated by estimating equation (8). The values of $\lambda$ from the pooled OLS estimator for groups lie in the same range as for the year-specific case. The results are tested for significance using an adjusted Wald test. Table $2.4(a, b, c)$ shows that the same results are obtained when the survivor bias is not corrected, and the results are calculated over groups for surviving firms, and when survivor bias is considered and overall sample is considered into the analysis. There is no evidence of a difference in learning rates. These results are discussed in the next section. 
Table 2.4 (a) Comparison of surviving firms and entire sample using Pooled OLS Estimator

\begin{tabular}{|c|c|c|c|c|}
\hline Groups & $\begin{array}{c}\text { Surviving } \\
\text { Firms: } \lambda\end{array}$ & $\begin{array}{c}\text { Significance } \\
\text { across } \\
\text { groups }\end{array}$ & $\begin{array}{c}\text { All } \\
\text { firms: } \\
\lambda\end{array}$ & $\begin{array}{c}\text { Significance } \\
\text { across } \\
\text { groups }\end{array}$ \\
\hline Pooled & $\begin{array}{c}0.20 * * * \\
(0.01)\end{array}$ & - & $\begin{array}{c}0.21 * * * \\
(0.01)\end{array}$ & - \\
\hline $\mathrm{R}^{2}$ & 0.65 & & 0.65 & \\
\hline \multicolumn{5}{|c|}{ Owner Specific } \\
\hline Female & $\begin{array}{c}0.21 * * * \\
(0.02)\end{array}$ & & $\begin{array}{c}0.29 * * * \\
(0.03)\end{array}$ & \\
\hline Male & $\begin{array}{c}0.20 * * * \\
(0.01)\end{array}$ & No & $\begin{array}{c}0.21 * * * \\
(0.01)\end{array}$ & No \\
\hline $\mathrm{R}^{2}$ & 0.65 & & 0.65 & \\
\hline Older & $\begin{array}{c}0.20 * * * \\
(0.01)\end{array}$ & & $\begin{array}{c}0.20 * * * \\
(0.01)\end{array}$ & \\
\hline Younger & $\begin{array}{c}0.21 * * * \\
(0.02)\end{array}$ & No & $\begin{array}{c}0.21 * * * \\
(0.02)\end{array}$ & No \\
\hline $\mathrm{R}^{2}$ & 0.65 & & 0.65 & \\
\hline $\mathrm{N}$ & 7835 & & 9474 & \\
\hline
\end{tabular}

Significance of lambda for each group is tested using a Wald Test.

Significance of lambda across groups is tested using an Adjusted Wald test.

$* \mathrm{p}<.10, * * \mathrm{p}<.05, * * * \mathrm{p}<.01$ 
Table 2.4 (b) Comparison of surviving firms and entire sample using Pooled OLS Estimator

\begin{tabular}{|c|c|c|c|c|}
\hline \multicolumn{5}{|c|}{ Firm Specific } \\
\hline Groups & $\begin{array}{c}\text { Surviving } \\
\text { Firms: } \lambda\end{array}$ & $\begin{array}{c}\text { Significance } \\
\text { across } \\
\text { groups }\end{array}$ & $\begin{array}{c}\text { All } \\
\text { firms: } \\
\lambda\end{array}$ & $\begin{array}{c}\text { Significance } \\
\text { across } \\
\text { groups }\end{array}$ \\
\hline $\begin{array}{c}\text { Home } \\
\text { Based } \\
\mathrm{R}^{2}\end{array}$ & $\begin{array}{c}0.18 * * * \\
(0.01) \\
0.65\end{array}$ & Yes * & $\begin{array}{c}0.18 * * * \\
(0.01) \\
0.65\end{array}$ & Yes * \\
\hline Rented & $\begin{array}{c}0.28 * * * \\
(0.02)\end{array}$ & Yes* & $\begin{array}{c}0.28 * * * \\
(0.02)\end{array}$ & Yes* \\
\hline $\mathrm{R}^{2}$ & 0.65 & & 0.65 & \\
\hline $\begin{array}{c}\text { Other } \\
\text { Location }\end{array}$ & $\begin{array}{c}0.20 * * * \\
(0.02)\end{array}$ & No & $\begin{array}{c}0.21 * * * \\
(0.02)\end{array}$ & No \\
\hline $\mathrm{R}^{2}$ & 0.65 & & 0.65 & \\
\hline Employer & $\begin{array}{c}0.25 * * * \\
(0.01)\end{array}$ & & $\begin{array}{c}0.25 * * * \\
(0.01)\end{array}$ & \\
\hline $\begin{array}{c}\text { Non } \\
\text { Employer }\end{array}$ & $\begin{array}{c}0.18 * * * \\
(0.01)\end{array}$ & Yes** & $\begin{array}{c}0.18 * * * \\
(0.01)\end{array}$ & Yes** \\
\hline $\mathrm{R}^{2}$ & 0.65 & & 0.65 & \\
\hline $\begin{array}{c}\text { Sole } \\
\text { Proprietor }\end{array}$ & $\begin{array}{c}0.20 * * * \\
(0.01)\end{array}$ & No & $\begin{array}{c}0.20 * * * \\
(0.01)\end{array}$ & No \\
\hline $\mathrm{R}^{2}$ & 0.65 & & 0.65 & \\
\hline Corporation & $\begin{array}{c}0.30 * * * \\
(0.02)\end{array}$ & Yes*** & $\begin{array}{c}0.29 * * * \\
(0.02)\end{array}$ & Yes*** \\
\hline $\mathrm{R}^{2}$ & 0.65 & & 0.65 & \\
\hline Other Legal & $\begin{array}{c}0.16^{* * *} \\
(0.01)\end{array}$ & Yes* & $\begin{array}{c}0.17 * * * \\
(0.01)\end{array}$ & Yes * \\
\hline $\mathrm{R}^{2}$ & 0.65 & & 0.65 & \\
\hline $\mathrm{N}$ & 7835 & & 9474 & \\
\hline
\end{tabular}

Significance of lambda for each group is tested using a Wald Test.

Significance of lambda across groups is tested using an Adjusted Wald test.

$* \mathrm{p}<.10, * * \mathrm{p}<.05, * * * \mathrm{p}<.01$ 
Table 2.4 (c) Comparison of surviving firms and entire sample using Pooled OLS Estimator

\begin{tabular}{|c|c|c|c|c|}
\hline \multicolumn{5}{|c|}{ Industry- Specific } \\
\hline Groups & $\begin{array}{c}\text { Surviving } \\
\text { Firms: } \lambda\end{array}$ & $\begin{array}{c}\text { Significance } \\
\text { across } \\
\text { groups }\end{array}$ & $\begin{array}{c}\text { All } \\
\text { firms: } \\
\lambda\end{array}$ & $\begin{array}{c}\text { Significance } \\
\text { across } \\
\text { groups }\end{array}$ \\
\hline Hi-tech & $\begin{array}{c}0.20^{* * * *} \\
(0.02)\end{array}$ & No & $\begin{array}{c}0.19 * * * \\
(0.02)\end{array}$ & No \\
\hline $\mathrm{R}^{2}$ & 0.65 & & 0.65 & \\
\hline Med-tech & $\begin{array}{c}0.20 * * * \\
(0.01)\end{array}$ & No & $\begin{array}{c}0.20^{* * * *} \\
(0.01)\end{array}$ & No \\
\hline $\mathrm{R}^{2}$ & 0.65 & & 0.65 & \\
\hline Low-tech & $\begin{array}{c}0.20^{* * * *} \\
(0.01)\end{array}$ & No & $\begin{array}{c}0.21 * * * \\
(0.01)\end{array}$ & No \\
\hline $\mathrm{R}^{2}$ & 0.65 & & 0.65 & \\
\hline $\mathrm{N}$ & 7835 & & 9474 & \\
\hline
\end{tabular}

Significance of lambda for each group is tested using a Wald Test. Significance of lambda across groups is tested using an Adjusted Wald test. $* \mathrm{p}<.10, * * \mathrm{p}<.05, * * * \mathrm{p}<.01$

\subsubsection{Estimation across groups}

Except for the firm-specific categorization, none of the groups show an evidence of significant differences in learning rates between groups. Considering the firm-specific categorization, businesses located in the rented space, firms which have employees working in it, and firms established as corporations, show a higher speed of learning as compared to their counterparts. A home office as the primary business location with no employees adds flexibility to the working schedule of an entrepreneur that might make him complacent. In addition, home-based businesses are established as sole proprietorships. In this study, $21 \%$ of the firms are established as sole proprietorships and are located in the home, as compared to only $11 \%$ of the firms established as 
corporations. Having employees as a support system, and established as a corporation makes an entrepreneur more active that makes him assign a higher weight to the market signals. There is evidence that the choice of legal status with which a firm is established speaks a lot about the long term goals of the owner (Frankish et al. 2007), where firms established as corporations have higher growth targets. The reason for this could be that hiring people and working as a corporation generates an expectation that entrepreneurs should at least be familiar with labor and corporate laws. To illustrate, if a firm operates as a corporation which produces chemicals, then providing a safe working environment to his employees is a legal requirement. Being a corporation exerts an extra pressure on the owner that is reflected in assigning a higher weight to the current market signals.

Considering the owner-specific sub-group, the speed of learning is higher for younger entrepreneurs; however, the results are not significant. An older entrepreneur would probably have a repertoire of references that he gained from his past beliefs and/or experiences, making him less amenable to the current market signals. In contrast, when it comes to the entrepreneurs who are young and at the same time new in business, they would assign more weight on the market signals, thereby leaving them with a higher speed of learning.

Analyzing the results over the gender differentials yield mixed results. For the surviving firms, female entrepreneurs show a higher speed of learning as compared to male entrepreneurs, whereas for the entire sample male entrepreneurs show a higher speed of learning. Despite the fact that firms with male entrepreneurs have a higher survival rate (86\%) as compared to women entrepreneurs $(82 \%)$, firms which survive all six years show a higher female entrepreneur speed of learning. In other words, women 
learn over a period of time, and for the successful firms that survived the first six years, women assign a higher weight to the market signals as compared to men.

Further, firms operating in low-tech industries generate a higher speed of learning. One of the reasons for the speed of learning to be lower in the high-technology industry is cited by Baloff (1971). He suggests that there are two stages of learning: in the initial phase a firm begins the manufacturing process, and reaches a point when there is no further learning that leads to "plateauing in the learning curve". Yelle (1979) mentions that firms which are more "machine-intensive" have a higher ratio of machine to total labor, and a lower progress ratio. Moreover, Klenow (1998) in his research on learningby-doing mentions that, "the more production experience the firm has with a technology, the less it has left to learn". Therefore, in this study scope to learn explains a higher speed of learning for firms in low-tech industries.

To check for robustness of results, a variation in the utility and a cost function with a non-linear functional form is tested for. It should be noted that the same methodology is followed to test for non-linearity in the utility function as adopted by Parker. Up to six powers of Taylor approximation is tested for, and there is no evidence of non-linearity even in this data-set, and the linear functional form is a robust specification. Starting with $j=2,3 \ldots 5$, the coefficients are not significantly different from zero.

The above mentioned analysis displays a declining speed of learning. However, the adaptive expectations model presented by Parker treats $\lambda$ to be a constant that does not conform to the above result. The next section provides evidence using a Bayesian 
learning framework and proves that $\lambda$ is not constant; rather it declines with the age of the firm.

\subsubsection{Interpretation of results using Bayesian framework}

Interpreting the results in light of Bayesian framework, consider equation (7), which shows the effort level that maximizes the expected net revenue. Let $\bar{p}_{i t}$ denote the expected value of $p$ at time $t$, i.e., $E\left(p_{i t} \mid \Omega_{i t}\right)$. Equation (7) can be rewritten as:

$h_{i t}=\gamma \bar{p}_{i t}-\gamma \phi_{i}+\underline{H}$.

Equation (5) and (9) yield the following profit equation for an entrepreneur $i$ :

$\Pi_{i t}=\gamma p_{t} \bar{p}_{t}-\gamma \bar{p}_{t} \phi_{t}$

If $\phi_{i}$ is known to an entrepreneur with certainty, then he would immediately learn the true productivity, $p$. However, as there is noise associated with the marginal operating cost of effort, an entrepreneur can only observe a signal, $z_{t}=p+\varepsilon_{t}$, where $\operatorname{var}(\varepsilon)=\sigma^{2}$. Suppose that, $i$ 's prior belief about the true productivity, $p$, is that it is a draw from a Normal distribution with mean $\theta$ and variance $\sigma_{\theta}^{2}$; and that the signals, $z$, about $p$ are random draws from a Normal distribution with mean $p$ and variance $\sigma^{2}$. Let $\bar{z}_{t}$ denote the mean of the $t$ signals observed up to period $t$. Using standard formulae for the normal conjugate family (DeGroot, 1970, p.166), i's posterior belief is Normal with mean:

$\bar{p}_{t}=\frac{\theta \sigma^{2}}{\sigma^{2}+t \sigma_{\theta}^{2}}+\frac{\bar{z}_{t} t \sigma_{\theta}^{2}}{\sigma^{2}+t \sigma_{\theta}^{2}}$,

and variance

$\sigma_{t}^{2}=\frac{\sigma^{2} \sigma_{\theta}^{2}}{\sigma^{2}+t \sigma_{\theta}^{2}}$ 
The variance of beliefs is a deterministic function of time; the pair $\left\{\bar{p}_{t}, t\right\}$ is a sufficient statistic for current beliefs. The evolution of beliefs over time can be described by a transition function, $b\left(z, \bar{p}_{t}, t\right)$ that maps a Normal distribution, with mean $\bar{p}_{t}$ and variance $\sigma_{t}^{2}$ (Easley \& Kiefer, 1988: 1050), into a Normal distribution with mean:

$\bar{p}_{t+1}=\frac{\bar{p}_{t} \sigma^{2}+z_{t+1} \sigma_{\mathrm{t}}^{2}}{\sigma^{2}+\sigma_{t}^{2}}$

and variance

$\sigma_{t+1}^{2}=\frac{\sigma^{2} \sigma_{\mathrm{t}}^{2}}{\sigma^{2}+\sigma_{t}^{2}}$

It should be noted that $E\left[z_{t+1} \mid \bar{p}_{t}\right]=\bar{p}_{t}$ which implies that $E\left[\bar{p}_{t+1} \mid \bar{p}_{t}\right]=\bar{p}_{t}$ in equation (13). Equation (12) and (13) together yield the conditional variance of the subjective mean as

$\operatorname{var}\left(\bar{p}_{t+1} \mid \bar{p}_{t}\right)=\frac{\sigma^{2} \sigma_{\theta}^{4}}{\left(\sigma^{2}+(t+1) \sigma_{\theta}^{2}\right)^{2}}$

The variance of $\bar{p}_{t}$ declines as experience progresses at the rate $O\left(t^{-2}\right)$. As the optimal amount of effort is linear in $t$, variance of $h_{t}$ also declines at the rate $O\left(t^{-2}\right)$. Therefore a simple Bayesian model predicts a declining variability in hours worked. To see it more precisely, rewriting equation (13) and substituting the value of $\sigma_{t}^{2}$ from (12) gives

$\bar{p}_{t+1}=\frac{\bar{p}_{t} \sigma^{2}}{\sigma^{2}+\sigma_{t}^{2}}+\frac{z_{t+1} \sigma_{\mathrm{t}}^{2}}{\sigma^{2}+\sigma_{t}^{2}}$ 
$\bar{p}_{t+1}=\frac{\bar{p}_{t}\left(\sigma^{2}+t \sigma_{\theta}^{2}\right)}{\sigma^{2}+(t+1) \sigma_{\theta}^{2}}+\frac{z_{t+1} \sigma_{\theta}^{2}}{\sigma^{2}+(t+1) \sigma_{\theta}^{2}}$.

The above expression explains that as the firm gets older (i.e., as $t$ gets larger), less weight is put on the new information, and it suggests a Bayesian model rather than the adaptive expectations model written by Parker. Parker's framework would say beliefs take the form of an adaptive expectations rule and are like:

$\bar{p}_{t+1}=(1-\lambda) \bar{p}_{t}+\lambda z_{t+1}$

Comparing equation (18) with the Bayesian framework in equation (17), it is interpreted that $\lambda$ is not constant. Instead, (18) can be rewritten as:

$\bar{p}_{t+1}=\left(1-\lambda_{t+1}\right) \bar{p}_{t}+\lambda_{t+1} z_{t+1}$

Combining equation (17) and (19), after backdating them by one period gives an equation for $\lambda$, which is strictly decreasing in $t$.

$\lambda_{t}=\frac{\sigma_{\theta}^{2}}{\sigma^{2}+t \sigma_{\theta}^{2}}$.

Therefore, the speed of learning is declining with the age of the firm. Interpreting the different rates of $\lambda$ across at any given point in time, consider two groups, A and B. Assuming that group A has a higher estimated $\lambda$ than group B, it can be good or bad news for group A. Consider two scenarios:

- If Group A has a higher variance for prior beliefs, $\sigma_{\theta}^{2}$, but the same variance for the current signals, $\sigma^{2}$, this implies that group A has no more precise signals than group B, but it knows less to start with. One supposes less precise signals are bad for group A. It only appears to learn faster because it initially knows less, and 
therefore has more to learn. But group A is always inferior to group B because it always knows less. Linking it with the empirical findings, younger entrepreneur, and entrepreneurs operating in low-tech industries know less to start with, resulting in a higher speed of learning. They are similar to group $\mathrm{A}$ in the example.

- If Group A has the same variance for prior beliefs, $\sigma_{\theta}^{2}$, but a lower variance for the current signals, $\sigma^{2}$, this implies that group A has more precise signals than group B, but it initially knows exactly the same. One supposes more precise signals are good for group A. It learns faster because its new information is more precise. Group A always knows more than B, in this case.

It can be inferred that a higher $\lambda$ is not necessarily a good thing. Even with a higher $\lambda$, one group could be better or worse than the other. Further, to gain evidence of the result from the Bayesian learning, the next section analyzes whether there is a relation between $\lambda$ and firm growth. In other words, it examines whether a higher $\lambda$ is reflected in the firm's performance.

\subsubsection{Linkage with firm growth}

To maintain uniformity, the same cross-section of firms is used for measuring the firm growth as for the speed of learning. Relative growth percentage (2004 as the base year and 2009 as the final year) for each group is calculated rather than calculating the average growth rate over six years.

Growth rate is calculated only for surviving firms, for the reason that these firms survived the initial hiccups which transpire with the "liability of newness" and "liability of smallness" (Gilbert et al., 2006). Researchers have mentioned that firms which survive 
the whole period should be considered for accurate analysis. To illustrate, Hart \& Prais (1956) while analyzing business concentration highlighted that firms that are alive until the end of the analysis will have an undue effect on the analysis if considered along with the firms that exit the sample set midway. Audretsch et al. (2004), mention that growth pattern should be analyzed only for firms that do not exit the market, and stay in business. In this context, Petrunia (2008) aptly remarks that, "it is difficult to know what growth persistence means for firms that exit an industry. Death is an absorbing state so growth persistence is meaningless for exiting firms." Moreover the initial super high, or low growth rates will not have any influence on the calculation of growth rates. It should be noted that there is no attempt to measure the determinants of growth in this study. The focus is on ascertaining the differentials in the growth rates over the cross-section of firms.

There is no unanimity on what constitutes growth of a firm which makes it even more crucial to specify the methodology used to measure it (Diambeidou et al., 2007; Korunka et al., 2011). Where increase in total assets might sound like a viable option to measure growth for a firm involved in construction and manufacturing, it would be the least preferable variable to capture growth for a firm involved in the services sector (see Dobbs \& Hamilton, 2006). Researchers have used various measures to account for firm growth which range from increase in tangibles like total assets, sales and employees to intangibles like profit, return on assets employed and revenue (Delmar, 1997; Davidsson et al., 2006; Garnsey et al., 2006; Gilbert et al., 2006).

For this analysis, return on asset (ROA) is calculated to represent the firm growth rate as shown in equation (21). It measures the return per dollar over total assets that 
constitute a sum total of borrowed money and owner's equity. It accounts for the efficiency of the firm in addition to the profitability of the firm.

Return on Assets $($ ROA $)=$ Net Earnings $/$ Total Assets

Let $R O A_{i k t}$ represent the return on asset of $i^{\text {th }}$ firm, belonging to a group $k$ at time $t$, where $\mathrm{i} \in\{$ Firms which survived six years $\}$, and $t \in\{1, \ldots, 6\}$. The difference in $R O A$ between $t=6$ and $t=1$ gives an absolute growth $\left(G_{i k t}\right)$ as shown in equation (22) and relative growth rate $\left(g_{i k t}\right)$ shown in equation (23).

$$
\begin{aligned}
G_{i k t} & =R O A_{i k t=6}-R O A_{i k t=1}, \\
g_{i k t} & =\frac{R O A_{i k t=6}-R O A_{i k t=1}}{R O A_{i k t=1}} .
\end{aligned}
$$

Return on asset gives a comprehensive view that captures debt, equity and profit all in one. Analyzing the growth rate for the surviving firms, it is only for firm-specific categorization of employer firms that generate a higher speed of learning, and a higher growth rate (see Table 2.5). Except for this group, every other classification displays no relation between the speed of learning and firm growth.

However, there is clear evidence that firms with higher growth rate are the firms that survived more. To illustrate, owner-specific categories, men and older entrepreneurs show a higher growth rate and a higher survival rate, despite the fact that both these categorizations show a lower speed of learning. A similar result is observed for firms that are in medium technology industries. It should be noted that longer surviving firms have a higher rate of growth because, irrespective of learning, productivity rises with the firm's age (Irwin \& Klenow, 1994). Therefore, the above analysis strengthens the result 
obtained earlier that there is no reason to expect $\lambda$ to be related to performance in one direction over another.

Table 2.5 Comparison of learning speed, growth rate $\&$ rate of survival: Surviving firms

\begin{tabular}{|c|c|c|c|c|c|}
\hline Groups & $\begin{array}{l}\text { Speed of } \\
\text { learning: } \lambda\end{array}$ & $\begin{array}{l}\text { Growth rate: } \\
\text { Return on } \\
\text { Asset }\end{array}$ & $\begin{array}{l}\text { Speed of } \\
\text { learning } \\
\text { higher for } \\
\text { which group? }\end{array}$ & $\begin{array}{l}\text { Return on } \\
\text { asset higher } \\
\text { for which } \\
\text { group? }\end{array}$ & $\begin{array}{l}\text { Survival } \\
\text { rate higher } \\
\text { for which } \\
\text { group? }\end{array}$ \\
\hline \multicolumn{6}{|l|}{ Owner Specific } \\
\hline Female & 0.21 & 2.64 & \multirow[b]{2}{*}{ Female } & \multirow[b]{2}{*}{ Male } & \multirow[b]{2}{*}{ Male } \\
\hline Male & 0.20 & 9.23 & & & \\
\hline Older & 0.20 & 7.99 & \multirow[b]{2}{*}{ Younger } & \multirow[b]{2}{*}{ Older } & \multirow[b]{2}{*}{ Older } \\
\hline Younger & 0.21 & 7.15 & & & \\
\hline \multicolumn{6}{|l|}{ Firm-Specific } \\
\hline Home Based & 0.18 & 4.06 & & & \\
\hline Rented & 0.28 & 11.83 & \multirow[b]{2}{*}{ Rented $* * *$} & \multirow[b]{2}{*}{ Other Location } & \multirow[b]{2}{*}{ Other Location } \\
\hline Other Location & 0.20 & 12.13 & & & \\
\hline Employer & 0.25 & 7.99 & \multirow[b]{2}{*}{ Employer ** } & \multirow[b]{2}{*}{ Employer } & \multirow[b]{2}{*}{ Employer } \\
\hline Non Employer & 0.18 & 7.33 & & & \\
\hline Sole Proprietor & 0.20 & 5.39 & & & \\
\hline Corporation & 0.30 & 8.44 & \multirow[b]{2}{*}{ Corporation*** } & \multirow[b]{2}{*}{ Corporation } & \multirow[b]{2}{*}{ Other Legal } \\
\hline Other Legal & 0.16 & 9.69 & & & \\
\hline \multicolumn{6}{|c|}{ Industry-Specific } \\
\hline Hi-tech & 0.20 & 0.48 & & & \\
\hline Med-tech & 0.20 & 10.38 & \multirow[b]{2}{*}{ Low-tech } & \multirow[b]{2}{*}{ Med-tech } & \multirow[b]{2}{*}{ Med-tech } \\
\hline Low-tech & 0.20 & 7.59 & & & \\
\hline
\end{tabular}




\subsection{Conclusion}

One of the consistent and significant results from the above analysis is that speed of learning declines with the age of the firm. The decline in speed of learning is consistent with the framework of Bayesian learning where $\lambda$ is not treated as constant; rather it is determined from the mix of prior beliefs and current signals. Parker's framework is based on adaptive expectations that treats $\lambda$ as a constant, and presents little evidence on the declining speed of learning.

Further, it is inferred that a higher speed of entrepreneurial learning is not desirable, and there is no reason to expect a positive relation between entrepreneurial leaning and firm growth in this framework. Instead, firm survival and growth rate are positively related. The result holds even after firm attrition has been taken into consideration. Even though there is no linkage between faster speed of learning and firm growth, policy intervention in the form of assistance to start-ups in the initial years seems a plausible method to detect the under-performers. Capturing learning, in its true sense, is contingent on the correct estimates of signals an entrepreneur receives and his initial knowledge. Cassar and Craig (2009) mention that entrepreneurs who rely more on their past beliefs suffer from "hindsight bias" that affects their ability to make accurate decisions (p.150). It is likely that there are bound to be distortions and errors even while recalling the past information, which is thought to be more of a characteristic feature while decoding the current noisy market signals. Therefore, there is presence of an error component in both: forward looking approach of relying on current signals and backward looking framework of recalling past information from already established beliefs. The fact that how an entrepreneur extracts relevant information from each extra signal, and 
maintains a balance between past beliefs and current signals, captures his speed of learning.

Moreover, looking at the results intuitively, why would an entrepreneur assign increasing weights to the newer noisy market signals when he has already learned to extract the relevant information from past beliefs? If weights for newer signals increase, this implies there is no permanent learning, with no formation of beliefs that could have served as a ready reference for the future. The structure of learning is reflected in the higher survival rate along with the firm's better performance. Identifying the worth of each new signal differentiates the true learning parameters of the entrepreneurs. As Casson (1982) aptly pointed out that an entrepreneur "learns from the deals that he makes, and he learns from the deals that fall through" (p 386). Therefore, in the first place, each owner receives a different set of signals from the market that differentiates their behavior and actions. Even though entrepreneurs somehow receive the same information set, the processing and assimilating speed differs between them, which differentiate the successful entrepreneurs from non-successful entrepreneurs (Frankish et al., 2007).

To conclude, true learning enables formation of correct estimates and segregation of good from bad signals. Assigning less weight to the new signals does not imply that an entrepreneur is not learning. Past beliefs could be equally informative if the posterior belief was updated correctly in the light of new information. 


\section{Chapter 3: Diversification and Survival by Business Start-ups}

\subsection{Introduction}

Despite the fact that growth and survival of small firms have been explored in detail, diversification as one of the strategies for growth has not received the attention it deserves. As a result, studies that explore diversification activities by small firms have examined conventional research questions like, do small firms see diversification as a growth strategy, and is there a positive association between diversification and performance? If yes, then, is the relation linear or curvilinear (Auerswald, 2008; Baptista et al., 2010; Doving \& Gooderham, 2008; Giarratana, 2004; Kim \& Kogut, 1996; Lynn, 1998; Lynn \& Reinsch, 1990; Sandvig, 2000)?

These studies show that small firms see diversification as one of the strategies for growth. However, they do not explore at what stage of the business an entrepreneur decides to add new products or enter into new areas. One of the questions that an entrepreneur of a young firm faces is: "When to diversify"? Expansion of the product portfolio and geographical areas is one of the key factors that affect a firm's survival and growth, and equally important is the timing of such an expansion.

However, due to data limitations, it is hard to identify when a business start-up diversifies, and whether diversification is related to the business or an unrelated one. This paper seeks answers to the following questions for business start-ups: (i) at what stage a business start-up diversifies; (ii) is there an association between timing of diversification and survival? In other words, whether diversifying at an early stage affects the survival rate; and (iii) how long the effect of early diversification lasts, or does positive effect of diversification show any persistence? 
A seven year (2004-2010) confidential micro-data provided by the KFS through the NORC data enclave is used in this essay. To test for the timing and persistence of diversification by start-ups, this study uses a Cox Proportional Hazard Model. The empirical results in this study provide evidence that the majority of firms diversify in the first year. Also, the firms diversifying at an early stage in their lives show a higher survival rate. Further, the effect of adopting an early diversification strategy fades over a period of time.

The study contributes to the existing knowledge of firm survival by adding the dimension of diversification, and its timing by business start-ups. It presents a better perspective of timing of diversification to the owners. Diversification can be a strategy for young firms seeking growth, or simply seeking survival in the industry. In both cases, when to diversify is an important decision that an owner has to make. Owners will be better able to evaluate their chances of success once they know when to undertake diversification activities. In this study, early diversifiers show a lower hazard of exit; however, this effect fades out over a period of time. This implies that entrepreneurs should try and leverage on the adoption of early diversification strategy. There is evidence that an advantage gained in the initial years can yield lasting effects at the later stages. At the same time, this advantage prepares an entrepreneur to recognize the opportunities, and deal with threats (Geroski et al., 2010). It therefore becomes important to build upon the advantage gained by the early diversifiers in the initial years.

In addition to making better decisions for the firm, owners will be aware of what to expect once they have diversified, and face competition in the industry (Mata \& Portugal, 2002). Therefore, owners can even form a judgment on the survival path of the 
competitors, based on the product mix of its competitors, and whether or not they are selling their goods in multiple markets.

Furthermore, accurate information on what affects a firm's performance, and makes a firm successful is important in formulating policy programs. Consequently, this analysis has some policy implications for the organizations like the Small Business Administration (SBA) and Service Corps of Retired Executives (SCORE), which train and assist business start-ups. If is it profitable for firms to diversify in the initial years, they can provide assistance to owners in venturing out, and exploring new areas early on.

The remainder of this paper is structured as follows. Section 3.2 explains why large firms diversify, and which perspective best explains the act of diversification by young firms. Section 3.3 describes the data and variables used for this study. Relevant variables are constructed based on the literature of young firm survival, their growth path, and the kind of diversification activities undertaken by them. Section 3.4 presents the empirical estimation of differences in the survival rates of diversifiers and nondiversifiers using a Cox Proportional Hazard Model. Furthermore, it presents KaplanMeier survival graph of firms by diversifiers and non-diversifiers. Section 3.5 presents the conclusion of the study with areas for future research.

\subsection{Diversification}

There is no clear evidence on what motivates a person to start a business; however, he may start a business out of "necessity", or out of "opportunity". Opportunity entrepreneurs enter into self-employment if they see a favorable environment to materialize their idea. On the other hand, necessity entrepreneurs start their own business because of limited/no employment opportunities in the labor market. There is evidence 
that highlights the relation between ability and self-employment, and corresponding earnings associated with it (Astebro et al., 2008; Block and Wagner, 2010; Thompson, 2011).

In the first case, where an entrepreneur is pro-active, and starts a business out of his own wish, and not because of some external factors, he will steer all the resources and use the skill set in expanding the business by creating synergies across all existing units in the firm. In other words, an owner can either combine the resources and create synergies within the firm, or collaborate with other firms in the industry with similar portfolios (Ansoff, 1965; Carter, 1977; Chatterjee, 1986). One of the underlying features of diversification and expansion in this case is that the entrepreneur has confidence in the success of the business.

In contrast, if the business is established because of the failure to find a job, or losing a job; an entrepreneur might want to save a dying business by re-routing the resources and his efforts into new areas. This implies that owners see diversification as one of the routes to save a dying business, as a strategy to mitigate the risk attached to one unit (Beattie, 1980; Booz et al., 1985; Jovanovic \& Gilbert, 1993; Lynn \& Reinsch, 1990), or even as a strategy to correct an entry mistake. Lynn (1998, p.42) identified such a diversification strategy as, "crisis diversification", and mentions that, “...an ownermanager diversifies because his/her established venture is perceived to be in serious operational or financial trouble. In this case, diversification is pursued to 'save' the primary business." 
The underlying point here is that a new business is an alignment of entrepreneurial effort, prior work experience, assets, human capital, equity and favorable environmental conditions. While the set of strategic resources may be endowed to an entrepreneur prior to entry in the market and establishing a new business, it is the cognition of an entrepreneur that enables him to better recognize the opportunities and threats in the market. An entrepreneur may accumulate the resources and expand the business in the later years. However, prior work experience and knowledge about the industry may act as an incentive for early diversification. It is therefore possible that even in the initial years of a firm's existence entrepreneurs diversify and expand the product mix and/or geographical areas.

Geroski et al, (2010, p.510) mention that "in many cases, founding and subsequent conditions can be similar." Incidentally, the KFS data demonstrates that a large percentage of firms have a high mean amount of initial assets ${ }^{13}$, revenue, and other important resources a firm requires in the initial years (see Table 1.2 for the descriptives). Furthermore, by definition, the level of education and prior experience of the owners will not change over a period of time. Alternatively, it can be inferred that an entrepreneur already possesses the skill set necessary to start a business similar to the existing one.

In addition, entrepreneurs do receive aid and advice from organizations that assist small businesses. Indeed that does increase the repertoire of knowledge in the top hierarchy. This implies that even in the initial years, start-up firms have the capability to enter into new areas, or add another product line. Nonetheless, they are sometimes

\footnotetext{
${ }^{13}$ Mean assets for years 1-4: $\$ 219,768$; almost $40 \%$ of businesses had assets in the range of $\$ 10,000$ $\$ 100,000$ in year 2004. Mean revenue for years 1-4: $\$ 247,604$. For further details see Robb et al., (2009)
} 
restricted by capacity and resources. Consequently, an entrepreneur builds the dynamic capabilities, accumulates the resources, and makes an attempt to overcome the capacity constraint by accessing the financial markets, and creating synergies across firms.

Excess resource theory does explain the motivation to diversify; alternatively, it is also interesting to observe how the process of business creation per-se is linked with the act of diversification by start-ups. This perspective on resource build-up is not only valid for large and established firms, but also for young and small businesses. The next section creates a link up with the literature on large firm diversification.

\subsubsection{Evidence from large firm diversification}

Focusing on large firms, Montgomery (1994) aptly summarizes why firms diversify. She talks about three broad perspectives: (i) market power view; (ii) resource view; and (iii) agency view. The market power view highlights that diversification leads to anti-competitive effects and helps a firm to gain "conglomerate power" (Hill, 1985, p. 828). This view is consistent with the objective of profit maximization. However, young and small business start-ups that struggle to survive will not diversify just to gain market power. Consequently, this view does not offer much explanation on why start-ups would diversify.

The agency view extends from the principal-agent problem, where managers work for shareholders in a corporate set-up. The two main features of the agency view, a corporate structure, and the existence of managers, who work for the owners of a company, are not representative of business start-ups. One of the major reasons, particularly relevant to this data, is that almost $36 \%$ of the firms are established as sole 
proprietorships, and only $40 \%$ of the firms have employees (Robb et al., 2010). Even the perspective of agency view explains a little about small business diversification.

Elaborating the seminal work of Penrose's "The Theory of the Growth of the Firm" (1959), Mahoney and Pandian (1992. p.363) mention that “...the resource based theory is concerned with the rate, direction, and performance implications of diversification..." In other words, firms are constrained by the amount of resources they have (Mahoney \& Pandian, 1992; Wernerfelt, 1984). These constraints could be lack of funds, labor and opportunities to invest, or even insufficient managerial capacity. Furthermore, these constraints also explain the differences in the speed with which each unit works, where underutilized units/products/services lead to "slack resources" (Chandler, 1962; Caves, 1980). Start-ups start small and gradually increase their size and assets (Mata et al., 1995). During this process they build up a stock of excess resources. Resource-based perspective provides the closest reasoning for diversification that is not only valid for big corporations, but also for small business start-ups. In this study, startups possess the required resources even in the initial years, which cause firms to show an early pattern of diversification.

Therefore, this study draws from two main strands of literature. First, firm diversification based on the resource-based view of the firm (Mahoney \& Pandian, 1992; Penrose, 1959; Wernerfelt, 1984); and second, young firm survival and founding conditions (Audretsch \& Mahmood, 1995; Bruderl, 1992; Geroski et al., 2010; Klepper, 2002; Romanelli, 1989). From the above discussion, it is inferred that, young firms can diversify even in the initial years of their existence. This proposition is tested using the KFS data, which is described in the next section. 


\subsection{Sample Description}

\subsubsection{Data}

The study uses confidential micro-data provided by the KFS through the NORC data enclave. This study focuses on data collected in the first seven years of a firm's existence (calendar years 2004-2010). The study only includes permanent failure and excludes firms that have been temporarily out of business. Refusals and non-responses have also been excluded from the data-set to maintain consistency in defining "failure". Accordingly, 1,999 firms are taken out from the sample because: (i) they temporarily went out of business, (ii) non-response/refusal, (iii) they were merged with another business or sold, or (iv) had missing data, or (v) reported no owner. The final sample size used in this study consists of 2,870 firms ${ }^{14}$.

The KFS provides NAICS and ZIP codes for each firm. This helps in categorizing the firms in different regions and labor market areas (LMA). "A general definition for a labor market area is an economically integrated geographic area within which individuals can reside, and find employment within a reasonable distance or can readily change employment without changing their place of residence. LMA are metropolitan areas, micropolitan areas, or small labor market areas" ${ }^{\prime 15}$. Labor markets are not based on the county lines; rather they are created by the interrelationships amongst buyers and sellers of labor in that area ${ }^{16}$. Based on this information, the KFS data is matched with the County Business Patterns (CBP) Series of the U.S. Census Bureau, and two industry

\footnotetext{
${ }^{14}$ For details on the construction of survey, see Chapter 1, section1.3.2.4

${ }^{15}$ Refer: http://www.bls.gov/lau/lmadir.pdf

${ }^{16}$ Refer: http://www.ers.usda.gov/data-products/commuting-zones-and-labor-marketareas/documentation.aspx
} 
indices are created that account for a region's localization and urbanization. The next subsection explains how variables are created.

\subsubsection{Variable construction}

\subsubsection{Diversification}

The way diversification is defined in this study is different from the traditional measures followed in the literature. Neither does this study use the standard product count (SIC Classification), nor does the categorical classification either by Rumelt (1974, 1982), or a composite index defined by Gort (1962). The reason is that the KFS does not report the SIC Code of products produced by the firms. However, the data does indicate whether the firm is manufacturing a product or providing a service. Further, the KFS also reports information on, "how many other new businesses has the owner started besides the existing business", and, "was this business/businesses in the same industry as the existing business ${ }^{17}$ "? These two variables form the basis of identifying diversification. This classification is closest to Ansoff's $(1957,1965)$ concept of diversification, which focuses on the entry of firms into new markets with new products (Lynn, 1998). In this study, diversification strategy is calculated on two counts:

1. Internal Diversification: adding products \&/or services - This captures the timing when a firm makes a switch from providing only a product/service to adding both a product and a service to its portfolio, and it is a dummy variable that takes value "1" if a firm diversifies, else " 0 ".

2. Multiple Firm Diversification: adding new businesses - This can further take two forms: (i) related diversification: adding a new business in the same industry as the

${ }^{17}$ For details, see Robb et al., (2009, 2010) 
existing business; (ii) unrelated diversification: adding a new business in a new industry that is different from the existing business. Related and unrelated diversifications are both dummy variables that take on values " 1 " if a firm diversifies, else " 0 ".

A firm is considered as a diversifier if it ever diversifies in either of the above mentioned classifications. The main focus of the study is to capture the timing when a firm first decides to venture into new area; therefore, a time-variant variable "diversified" is created. This time-varying indicator is equal to " 1 " in time $t$ if a firm had diversified prior to this, else " 0 ". To illustrate, if a firm diversifies in the first year, the variable takes value "1" from year 1 to 7 . However, if a firm diversifies in year two, the variable diversified, takes the value " 0 " in the first year, and starting the second year it takes the value " 1 ". To further examine whether the positive effect of diversification is persistent, another variable, "time since diversification" is created which is an interaction between time and the variable "diversified".

Therefore, once a firm diversifies it stays as diversified until the end of the study, or until it exits the market, whichever is earlier. Further, if a firm switches from a "nondiversifier" to a "diversifier" in the middle of the study; it is labeled as a diversifier from that year onwards, and it stays in the same category till the end.

Approximately $62 \%(1,798)$ of firms diversified in the very first year. The pace of venturing into newer areas dropped with time (see Table 3.1, which provides the numbers on firms that diversified and survived in each year). Approximately $91 \%$ of firms survived until the first follow-up survey. Survival rate for firms in the KFS is higher than 
in other records available on small businesses ${ }^{18}$. To illustrate, the U.S. Small Business Administration measures this one year survival rate to be $75 \%$ for the firms started in year 1997 (Robb et al., 2009). The initial sample in the KFS consists of 2,870 firms, of which 1,995 (64\%) are still in operation by the fifth follow-up survey. Using the Bureau of Labor Statistics data, Knaup \& Piazza (2007) measured the five year survival rate at $40 \%$. The KFS assigns this difference in survival rates to missing the failures in the year prior to the initial screening in 2004 (Renski, 2012).

Table 3.1 Composition of the Final KFS Sample

\begin{tabular}{rrrrrr}
\hline $\begin{array}{r}\text { Follow up } \\
\text { year }\end{array}$ & $\begin{array}{r}\text { Beginning } \\
\text { of the year }\end{array}$ & Exits & $\begin{array}{r}\text { Survival } \\
\text { rate (\%) }\end{array}$ & $\begin{array}{r}\text { No. Firms } \\
\text { Diversified }\end{array}$ & $\begin{array}{r}\text { \% Firms } \\
\text { Diversified }\end{array}$ \\
\hline 2004 & 2,870 & 230 & 91.99 & 1,798 & 62.64 \\
2005 & 2,640 & 488 & 83.00 & 169 & 6.40 \\
2006 & 2,382 & 718 & 74.98 & 62 & 2.60 \\
2007 & 2,152 & 875 & 69.51 & 40 & 1.85 \\
2008 & 1,995 & 1,013 & 64.70 & 12 & 0.60 \\
2009 & 1,857 & 1,130 & 60.63 & 16 & 0.86 \\
2010 & 1,740 & - & - & 9 & 0.51 \\
Total & - & - & - & 2,106 & - \\
\hline
\end{tabular}

\subsubsection{Firm specific variables}

Researchers have shown a strong linkage between the initial size of a start-up and its survival rate (Audretsch \& Mahmood 1995; Bruderl et al. 1992; Dunne \& Hughes 1994). Following the general practice, the total number of employees (full-time and parttime) is used to represent the current firm size (Mata et al., 1995; Mata \& Portugal, 1994). Owners are excluded while calculating total number of employees.

To account for the financial stability of a firm in the market, the credit rating of the firm is included as an explanatory variable. It takes values from 1 to 3 , "1" = high credit score, "2" = medium credit score, and " 3 " = low credit score. These credit ratings

\footnotetext{
${ }^{18}$ For details see Robb et al., (2010)
} 
are provided by Dun \& Bradstreet. It should be noted that the age of the firms is automatically controlled in the sample because all firms are born at the same time.

Firm growth is also added as an independent variable that differentiates the timing of diversification for firms with increasing or decreasing growth rates (Mata et al., 1995). If a firm is incurring losses and not growing, then a probable reason for diversification in this case, if there is any, would be to correct the entry mistake and minimize losses. In contrast, if the firm is growing and reports higher revenue, this implies that the firm has built up slack resources and pro-actively wants to diversify. For this analysis, the percentage change in the return on asset (ROA) for each contiguous year is calculated to represent the firm growth rate. It measures the return per dollar over total assets that constitute a sum total of borrowed money and owner's equity. Moreover it accounts for the efficiency of the firm, in addition to the profitability of the firm.

\subsubsection{Human capital}

Prior knowledge, work experience of the founding team, and the owner's level of education are considered as one of the significant predictors of business survival and success (Bates, 1990; Bruderl et al., 1992; Baptista \& Karaoz, 2006). Human capital of the firm in this study is measured using the following variables: (i) previous business experience of the main owner, (ii) main owner's education - the KFS reports education in the form of highest degree earned. This variable has been converted into years of education (see Table 3.2), (iii) age of the main owner. To capture non-linearity in age, age square is also added to the list of independent variables. 
Human capital renders competitive advantage to the firm that is unique to it, and cannot be imitated by its competitors (Geroski et al., 2010). The literature also suggests that, more than physical assets, it is the human capital that provides an edge to a firm when compared to similar firms in the industry (Teece, 1998). Therefore, intangible assets are measured by dividing the number of employees in $R \& D$, by the total number of employees in the firm. This will also capture the extent to which a firm is committed to improving its technological capabilities.

\section{Table 3.2 Years of Education}

\begin{tabular}{llc}
\hline Value & Description reported in the KFS & Converted to Years of Education \\
\hline 1 & Less than 9th grade & 5 \\
2 & Some high school, but no diploma & 9 \\
3 & High school graduate (diploma or equivalent & 12 \\
& diploma [GED]) & 13 \\
4 & Technical, trade or vocational degree & 13.5 \\
5 & Some college, but no degree & 14 \\
6 & Associate's degree & 16 \\
7 & Bachelor's degree & 16 \\
8 & Some graduate school but no degree & 18 \\
9 & Master's degree & 21 \\
10 & Professional school or doctorate & \\
\hline
\end{tabular}

\subsubsection{Industry and regional controls}

Favorable market conditions are considered to be an important determinant of firm survival and growth, and therefore they have a potential impact on the likelihood and timing of diversification activities. To illustrate, a friendly financial framework, and a supportive infrastructure will assist small business activities that would encourage them to undertake production of new goods into new markets. 
Industry and regional level controls are drawn from the literature, and include the variables that account for industry concentration, urbanization, and business cycles. (Agarwal \& Gort, 1996; Mata \& Portugal, 1994, 2002; Mata et al., 1995).

The literature on organizational ecology places a great emphasis on the total number of firms in the market, the distribution of large and small firms, and the level of urbanization in an area (Hannan \& Carrol, 1992). It has been established that these factors are not only important for the survival of a firm, they also facilitate diversification. The literature on industrial organization also suggests that market concentration promotes integration between, and across firms (Bunch and Smiley, 1992), which eventually adds to the portfolio of firms. In this study, Renski's classification (2012) is used to measure industry concentration and urbanization ${ }^{19}$. Employment and establishment data are derived from the CBP database of the U.S. Census Bureau for 2004, and then aggregated to the level of $\mathrm{LMA}^{20}$. The two variables created using this data are industry concentration and urbanization.

Industry concentration or localization represents the density of firms that are closely related, and is measured as the number of establishments in the same four digit NAICS industry as the start-ups in the KFS data. A highly concentrated market may show signs of stagnation in an industry, thereby motivating firms to look for opportunities to grow elsewhere. The level of urbanization is measured as the total number of employees in all industries in the LMA, and it serves as a control for localization. Urbanization may provide a supportive environment to start-ups by

\footnotetext{
${ }^{19}$ For details see Renski, (2012), The industry indices used in this study are created by Renski (2012)

${ }^{20}$ For a detailed analysis on computation of the variables, refer to: http://www.ers.usda.gov/data products/commuting-zones-and-labor-market-areas.aspx.
} 
providing better infrastructure and accessible resources. "While urban environments act as new firm incubators or nurseries, agglomeration diseconomies result in firm death or relocation (Fotopoulos \& Louri, 2000)." This implies that urbanization can generate results either in favor of firm survival or otherwise (Renski, 2009, 2012), depending on whether it yields economies or diseconomies.

Similar to the broader framework of industry urbanization, macroeconomic environment can also produce results in either direction. Favorable environmental conditions may make an entrepreneur complacent, with an expectation of growth in the same industry; or motivate him to explore new areas. To account for the great recession: a global economic decline that started in year 2007, and how the current state of economy affects the prospects of a business to venture into new areas, a dummy variable "business-cycle" is included. Business cycles are calculated using the unemployment rates from the Bureau of Labor Statistics ${ }^{21}$, that take "1" as a value if in the prior year the unemployment rate went down, else " 0 ".

Further, to account for differences across states, firms are categorized into six broad areas using the geographical codes (zip code, metropolitan statistical area, and state) provided in the data: 1-Midwest, 2-Southwest, 3-Northeast, 4-Southeast, 5-Central, 6-West. In the empirical analysis, results are compared with "Midwest" as the base. Survival rates also vary across industries. Consequently, six dummies are created that capture broad industrial classification: 1-Agriculture, Construction \& Transportation, 2Manufacturing, 3-Wholesale, Retail and Entertainment, 4-Information Services, 5-

\footnotetext{
${ }^{21}$ Refer: http://www.bls.gov/lau/\#tables
} 
Business Professional \& Administrative Services, 6-Other Services. Table 3.3 lists the variables used in the study along with the descriptive statistics.

\subsection{Empirical Estimation}

This section examines whether the timing of diversification affects the survival of start-ups. Two sets of analyses are conducted. The first plots a Kaplan-Meier survivor function. It compares the survival graphs for the firms based on time-varying variable diversified. In the second analysis, a semi-parametric Cox proportional hazard model is used to examine the survival pattern. The KFS uses a stratified sampling design, and the data is divided in three strata based on technology and gender. The KFS oversamples the firms in high-technology stratum. The empirical analysis therefore recognizes the survey nature of the KFS, and includes the sampling weights while conducting the survival analysis, making the results a representative of all firms in the United States. 
Table 3.3 Variable Definitions and Descriptive Statistics

\begin{tabular}{|c|c|c|c|}
\hline Variables & Description & Mean & Std.Dev. \\
\hline \multicolumn{4}{|l|}{ Firm Specific Variables } \\
\hline Firm Size & Number of Employees (Full Time and Part Time) & 2.35 & 8.15 \\
\hline Credit Ranking & $" 1 "=$ High, " $" "=$ Medium, " $3 "=$ Low & 2.00 & 0.61 \\
\hline Intangible Assets & No. of employees in R\&D divided by total no. of employees in the firm & 0.13 & 0.44 \\
\hline Firm Growth & Percentage change in return on asset $x 100$ & 0.61 & 39.07 \\
\hline \multicolumn{4}{|l|}{ Human Capital } \\
\hline Prior Work Experience & Years of work experience of the main owner in the same industry & 13.26 & 11.00 \\
\hline Education & Years of education of main owner & 15.27 & 2.51 \\
\hline Age & Age of the main owner at the start of business & 45.97 & 10.97 \\
\hline Age square & Age*Age & - & - \\
\hline \multicolumn{4}{|c|}{ Industry and Regional Controls } \\
\hline Concentration & $\begin{array}{l}\text { Number of establishments in same } 4 \text { digit NAICS industry as the start- } \\
\text { up } x 100\end{array}$ & 8.45 & 14.65 \\
\hline Urbanization & Number of employees in all industries in the LMA x 100,000 & 12.76 & 15.00 \\
\hline Business cycle & Bs cycle $=1$ if unemployment rate decreases, else $=0$ & 0.57 & 0.49 \\
\hline Region & $\begin{array}{l}6 \text { Regions: 1-Midwest, 2-Southwest, 3-Northeast, 4-Southeast, 5- } \\
\text { Central, 6-West }\end{array}$ & - & - \\
\hline Industry & $\begin{array}{l}6 \text { Industries: 1-Agriculture, Construction \& Transportation, 2- } \\
\text { Manufacturing, 3-Wholesale, Retail and Entertainment, 4-Information } \\
\text { Services, 5-Business Professional \& Administrative Services, 6-Other } \\
\text { Services }\end{array}$ & - & - \\
\hline
\end{tabular}




\subsubsection{Non parametric analysis}

Figure 3.1 presents a Kaplan-Meier comparative survival curve at time $t$ of all firms that had and had not diversified by time $t-1$. There is a clear evidence of firms that diversified at some point does show a higher survival rate as compared to nondiversifiers. Results have been tested for the equality of survivor functions across the diversifiers and non-diversifiers using a log-rank test. The log-rank test yields a chisquare value of 8.85 , which is significant at $1 \%$. Furthermore, after the second year, the two survivor curves are almost parallel, and the gap between the curves is also maintained. These results are put to empirical estimation using the Cox-proportional hazard model in the next sub-section.

Figure 3.1 Survivor Functions, by Time Variant Diversification

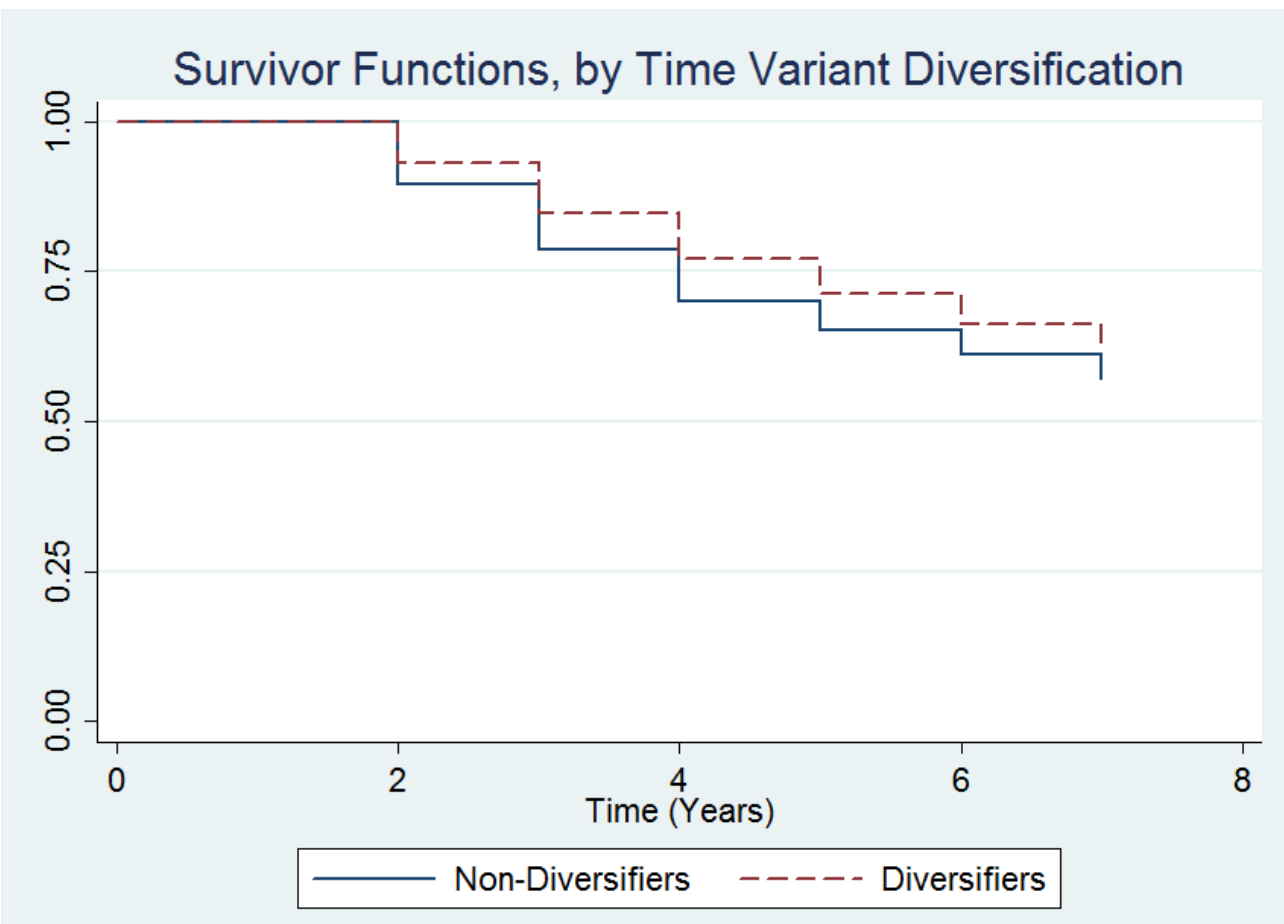




\subsubsection{Semi parametric analysis}

The dependent variable in this study is the binary variable that measures the likelihood of failure, and takes "1" as the value if a firm exits the market, else " 0 ". Independent variables are included based on their relevance in the literature of firm survival. The model can be written as:

$$
h_{j}(t)=h_{0}(t) e^{\left(\beta_{0}+x_{j} \beta_{x^{\prime}}\right)},
$$

Where $h_{j}$ is the hazard firm $j$ faces, and it is a function of baseline hazard, $h_{0}$, faced by everyone, and modified by $x_{j}$. The hazard faced by firm $j$ is multiplicatively proportional to the baseline hazard (Cox, 1972), thus named as the proportional hazards model. The Cox proportional hazard model is a semi-parametric model that assumes no parametric form of the survivor function, consequently, $h_{0}(t)$, the baseline hazard is left unestimated, and cancelled out while performing the binary outcome analysis. Examining the survivor curves explained in the above section, along with the empirical estimates offer a clear explanation for differences in the survival rates between early diversifiers and non-early diversifiers. Table 3.4 presents the results from the Cox-proportional hazard model, and lists both, the coefficients and hazard ratio.

The coefficient with negative sign indicates a positive effect on survival, and shows that the hazard of exit has decreased. Similarly, a positive coefficient shows a negative effect on survival and an increase in the hazard of exit. Hazard can be interpreted as the failure, and it describes the probability that a firm will exit the market, 
given it survived until the beginning of that year. If $S(t)$ represents the survivor function, hazard rate can be written as: $H(t)=-\ln \{S(t)\}$.

Interpreting the results in the light of the Cox-proportional hazard model, firms that diversify early, show a higher survival rate as compared to firms that do not diversify. The coefficient of the variable diversified is negative and statistically significant. In other words, whatever is the hazard rate at a particular time for the firms that do not diversify in year $t$, the hazard at the same time for those that do diversify is 0.55 times that hazard. Accordingly, all else equal, firms that diversify early are almost $1.8^{22}$ times more likely to survive as compared to firms that did not diversify, and survived that year.

The coefficient on variable, time since diversification is positive and statistically significant. This variable tests whether the positive effect of diversification is persistent or not; and a positive coefficient implies that this effect fades with time. The estimated effect of diversifying is zero after the fourth year ${ }^{23}$, and all firms face a hazard ratio of one. In other words, a hazard ratio of one implies that, variable time since diversification has no effect on baseline hazard after the fourth year. The important point to take from these results is that young firms do diversify early; and at the same time show a higher survival rate when compared to the non-diversifiers. However, this effect does not last for a long period of time, and starts to fade away.

${ }^{22}[\exp (0.550)=1.81]$

${ }^{23}$ Equating the coefficient of diversification, $b(t)=0=>-0.598+0.152 * t=0=>t=3.9$, This implies that, after year 4, the estimated effect of diversifying is zero. Similarly, hazard ratio, $h(t)=$ $\exp (-0.598+0.152 * 3.9)=1$ 
Table 3.4 Cox Proportional Hazard Estimates

\begin{tabular}{|c|c|c|}
\hline VARIABLES & $\begin{array}{c}\text { (1) } \\
\text { Coefficient } \\
\end{array}$ & $\begin{array}{c}(2) \\
\text { Hazard ratio } \\
\end{array}$ \\
\hline Diversified & $\begin{array}{c}-0.0598 * * * \\
(0.164)\end{array}$ & $\begin{array}{l}0.550 * * * \\
(0.090)\end{array}$ \\
\hline$t$ since diversification & $\begin{array}{l}0.152 * * * \\
(0.040)\end{array}$ & $\begin{array}{l}1.164 * * * \\
(0.047)\end{array}$ \\
\hline Medium Credit Rating & $\begin{array}{l}0.166^{*} \\
(0.095)\end{array}$ & $\begin{array}{l}1.180^{*} \\
(0.113)\end{array}$ \\
\hline Low Credit Rating & $\begin{array}{l}0.412 * * * \\
(0.110)\end{array}$ & $\begin{array}{l}1.510^{* * *} \\
(0.166)\end{array}$ \\
\hline Firm Size & $\begin{array}{l}-4.648 * * * \\
(0.604)\end{array}$ & $\begin{array}{l}0.010 * * * \\
(0.006)\end{array}$ \\
\hline Firm Growth Rate & $\begin{array}{l}-0.898 * * * \\
(0.062)\end{array}$ & $\begin{array}{l}0.407 * * * \\
(0.025)\end{array}$ \\
\hline Age of the Owner & $\begin{array}{l}-0.046^{*} \\
(0.018)\end{array}$ & $\begin{array}{l}0.955^{*} \\
(0.017)\end{array}$ \\
\hline Age Square & $\begin{array}{l}0.000 * \\
(0.000)\end{array}$ & $\begin{array}{l}1.000^{*} \\
(0.000)\end{array}$ \\
\hline Intangible Assets & $\begin{array}{c}0.149 \\
(0.186)\end{array}$ & $\begin{array}{c}1.161 \\
(0.216)\end{array}$ \\
\hline Work Experience & $\begin{array}{l}-0.006^{*} \\
(0.003)\end{array}$ & $\begin{array}{l}0.994 * \\
(0.003)\end{array}$ \\
\hline Education & $\begin{array}{l}-0.031 * \\
(0.014)\end{array}$ & $\begin{array}{l}0.970 * \\
(0.013)\end{array}$ \\
\hline Business Cycle & $\begin{array}{l}-1.410 \\
(0.000)\end{array}$ & $\begin{array}{c}0.244 \\
(0.000)\end{array}$ \\
\hline Concentration & $\begin{array}{l}-0.002 \\
(0.004)\end{array}$ & $\begin{array}{c}0.998 \\
(0.004)\end{array}$ \\
\hline Urbanization & $\begin{array}{l}0.002 * \\
(0.003)\end{array}$ & $\begin{array}{l}1.005^{*} \\
(0.003)\end{array}$ \\
\hline Southwest & $\begin{array}{l}0.255^{*} \\
(0.132)\end{array}$ & $\begin{array}{l}1.291 * \\
(0.170)\end{array}$ \\
\hline Northeast & $\begin{array}{l}-0.051 \\
(0.111)\end{array}$ & $\begin{array}{c}0.950 \\
(0.105)\end{array}$ \\
\hline Southeast & $\begin{array}{l}0.283 * \\
(0.103)\end{array}$ & $\begin{array}{l}1.328 * \\
(0.137)\end{array}$ \\
\hline Central & $\begin{array}{c}0.025 \\
(0.116)\end{array}$ & $\begin{array}{c}1.025 \\
(0.119)\end{array}$ \\
\hline West & $\begin{array}{l}0.206^{*} \\
(0.104)\end{array}$ & $\begin{array}{l}1.229 * \\
(0.128)\end{array}$ \\
\hline Observations & 14768 & 14768 \\
\hline Log likelihood & -6277 & -6277 \\
\hline Chi Square & 1788 & 1788 \\
\hline
\end{tabular}

Robust standard errors in parentheses $* * * \mathrm{p}<0.001, * * \mathrm{p}<0.005, * \mathrm{p}<0.10$ 
Firm specific variables yield expected results, where firms with larger size and a higher growth rate have a higher survival rate. Further, credit rating of the firm being a categorical variable, high credit ranking is the omitted group, and forms the base level for analysis. When compared with high credit rated firms, medium credit rating firms face $18 \%{ }^{24}$ greater hazard of exit. In addition, firms with lower credit rating face an even higher $\left(51 \%{ }^{25}\right)$ hazard of exit. This implies that a higher credit ranking does have a positive impact on the survival of young firms. Coefficient of intangible assets yields an insignificant result. The reason for this could be that young firms do not place much emphasis on the R\&D. Moreover, the majority of the firms in the data do not have employees working in the area of $R \& D$.

Analyzing the human capital of the firm, a one year increase in the age of an owner decreases the hazard by $4.5 \%$. This result becomes more meaningful, once read along with the coefficient of owner's work experience and education. Better education and a higher work experience do reduce the hazard of exit, as does the age of the owner. However, it should be noted that the magnitude is much less.

The variable "business cycle" is constructed using the current unemployment rates, and it shows a negative coefficient. This implies that a favorable business cycle, or a decrease in unemployment rate, decreases the hazard of exit; however the coefficient is insignificant. Analyzing the industry indices, higher concentration does result in a higher survival rate; however, the result is insignificant. Market concentration is defined as the

\footnotetext{
${ }^{24}[\exp (0.166)=1.180]$

${ }^{25}[\exp (0.418)=1.518]$
} 
number of establishments in the same industry as the start-up is. Incidentally, firms that are too concentrated give up on the competition, and increase the probability of survival.

One of the interesting results is given by the "industry urbanization". Existence of larger firms in this case lessened the survival chances of small business start-ups. As discussed earlier, urbanization can yield the results in either direction, causing economies or diseconomies. In this case, a higher level of urbanization causes net agglomeration diseconomies, which increases the hazard rate for start-ups. "Region" again is a categorical variable, and Midwest is the omitted variable and forms the basis of analysis. When compared with the Midwest, only the Northeast region shows a lower hazard of exit. Firms in the Northeast face $95 \%$ of the hazard that firms face in the Midwest; however, this result is insignificant. The rest of the regions show a higher hazard rate as compared to the Midwest; however, only the firms in the Central area show an insignificant result. The analysis also controlled for the industries, and the base industry is agriculture, manufacturing and transportation. When compared with the base industry, only "other services" show a higher and significant survival rate.

\subsection{Conclusion}

This paper examines the effect of early diversification strategy on the survival of firms. One of the significant results from the above analysis is that the majority of firms in the KFS diversified (in some form or another) in the first two years. This feature is consistent with a high survival rate, where early diversifiers did show a lower hazard of exit from the market.

It is generally expected that business start-ups do not undertake any diversification activity in the initial years. This study presents a contrary view, and 
demonstrates that out of $90 \%(2,870)$ of the firms that survived the first follow-up, $62 \%$ $(1,798)$ of the firms diversified, and stayed as diversifiers till the end of the study, or exit from the market, whichever was earlier.

The factors that affect the survival in this study are in consonance with the general literature on firm survival. Firm size and growth rate positively contribute towards the higher survival rate. The entrepreneur does play a significant role in the firm's survival and adoption of early diversification strategies. Education, work experience, and age all contribute positively towards the survival. Pre-entry experience in the same industry and education do show significant results.

Prior experience has proved to have a persistent effect on survival; and this effect is more pronounced if the work experience is in the same industry, which is the case in the sample under consideration (Klepper \& Simons, 2003; Thompson, 2005). For this reason, it can be interpreted that firms do have access to the resources even in the initial years. Linking this thought with the "resource based theory" also explains the reason for early diversification activity by the firms. Firms are capable of starting something similar and/or new with the amount of resources available to them.

Further, increased market concentration decreases the hazard of exit, which implies that a highly concentrated industry motivates a firm to diversify at an early stage. Stagnation in the market demand forces firms to expand their portfolio and geographical areas. Consequently, one can interpret that these firms did not diversify out of necessity, but chose diversification as one of their growth strategies. This is evident from the set of resources available to the start-ups in the form of personal assets, angel capital, venture capital, loan and debt. Developed financial market may contribute towards adoption of 
such a strategy. Furthermore, firms with a higher credit rating show higher survival rate that signals toward a developed capital market.

However, another important result from the study is that the positive effect of diversification decays over time, and after the fourth year all the firms face the same hazard of exit, irrespective of whether they diversified or not. In other words, positive effect of diversification is not persistent. There is evidence of founding conditions having lasting effects on a firm's growth and rate of survival (Audretsch \& Mahmood, 1995; Astebro \& Bernhardt, 2003; Huynh et al., 2008; Geroski et al. 2010; Mata et al. 1995). In contrast, in this study, the early effects of diversification decay after fourth year.

Therefore, favorable founding and current conditions help the firms to grow and proactively choose diversification as a growth strategy. In other words, the choices that start-ups make in the initial years do affect their survival; however, the effect of early diversification strategy dies off in the coming years. The study incorporates current as well as founding conditions of the firm and finds support for main drivers of survival: firm's growth, entrepreneurial experience, education, and urbanization.

One of the major limitations of the study is that it fails to address the problem of unobserved heterogeneity. Forward-looking entrepreneurs may show a lower hazard of exit, and a higher growth rate. In other words, entrepreneurs are not homogeneous, and high ability entrepreneurs may survive longer and show a higher rate of diversification. High ability entrepreneurs would be more motivated to diversify. In other words, firm survival and success are correlated with ability; however, ability remains unobservable.

An attempt was made to differentiate between the firms that diversify out of necessity, and firms that seek diversification as a growth strategy. However, due to 
missing observations, valid and meaningful results could not be obtained. There are limitations in the data that do not allow resolving this issue of unobserved heterogeneity. A variable "confidence" was created to capture entrepreneurial confidence in the business using survey questions: "did the business have a competitive advantage over their competitors", and second, "during the calendar year, was there any time when the business needed credit but did not apply because you or others associated with the business thought the application would be denied"? These variables reported more missing values, throwing out a lot of observations from the analysis. For future research, entrepreneurial confidence can be added into the analysis using additional years of data provided by the KFS.

Another area for future research is to ascertain what happens to the firms in the future years that choose to diversify, as compared to the firms that still choose to remain specialist (non-diversifier), and survive the follow-up years. In this study, the effect of early diversification is lost after the fourth year. Addressing the above two limitations with the additional data may highlight the effect of entrepreneurial motivation, and risk taking ability, on the adoption of diversification strategies, and survival rate. This question can be addressed with more waves of data being included for the analysis.

Nonetheless, the study tries to address the issue of timing and persistence of diversification for start-ups that has not been examined in detail. These results can be generalized across young firms in the U.S., and they do have policy implication for the agencies that assist and train small businesses, where they can provide assistance to the owners in venturing out, and exploring new areas at early stages. However, the main task 
for these organizations and entrepreneurs is to sustain the edge gained by a firm at an early stage of its existence. 


\section{REFERENCES}

Acs, Z. J., Anselin, L., \& Varga, A. (2002). Patents and innovation counts as measures of regional production of new knowledge. Research Policy, 31(7), 1069-1085.

Acs, Z. J., \& Audretsch, D. B. (1987). Innovation, market structure, and firm size. The Review of Economics and Statistics, 69(4), pp. 567-574.

Agarwal, R., \& Gort, M. (1996). The evolution of markets and entry, exit and survival of firms. The Review of Economics and Statistics, 489-498.

Albert, M. (2001). Bayesian learning and expectations formation: Anything goes. Foundations of Bayesianism, 24, 351-372.

Albuquerque, R., \& Hopenhayn, H. A. (2004). Optimal lending contracts and firm dynamics. The Review of Economic Studies, 71(2), pp. 285-315.

Ansoff, H. I. (1957). Strategies for diversification. Harvard Business Review, 35(5), $113-$ 124.

Ansoff, H. I. (1965). Corporate strategy: An analytic approach to business policy for growth and expansion McGraw-Hill New York.

Arthur, W. B. (1989). Competing technologies, increasing returns, and lock-in by historical events. The Economic Journal, 99(394), 116-131.

Åstebro, T., \& Bernhardt, I. (2003). Start-up financing, owner characteristics, and survival. Journal of Economics and Business, 55(4), 303-319.

Astebro, T., Chen, J., \& Thompson, P. (2008). Stars and misfits: A theory of occupational choice. Working Papers, Florida International University

Audretsch, D. B. (1995). Innovation, growth and survival. International Journal of Industrial Organization, 13(4), 441-457.

Audretsch, D. B., \& Acs, Z. J. (1994). New-firm startups, technology, and macroeconomic fluctuations. Small Business Economics, 6(6), 439-449.

Audretsch, D. B., \& Mahmood, T. (1995). New firm survival: New results using a hazard function. The Review of Economics and Statistics, 97-103.

Auerswald, P. E. (2008). Entrepreneurship in the theory of the firm. Small Business Economics, 30(2), 111-126. 
Baloff, N. (1971). Extension of the learning curve--some empirical results. Operational Research Quarterly, 329-340.

Baptista, R., \& Karaöz, M. (2006). Entrepreneurial human capital and the early survival chances of new start-ups: Opportunity-based vs. necessity-based entrepreneurship. Working Paper

Baptista, R., Karaöz, M., \& Leitão, J. (2010). Diversification by young, small firms. Paper Presented at the Summer Conference 2010, DRUID

Bates, T. (1990). Entrepreneur human capital inputs and small business longevity. The Review of Economics and Statistics,551-559.

Beattie, D. (1980). Conglomerate diversification and performance: A survey and time series analysis. Applied Economics, 12(3), 251-273.

Berk, J. B., Stanton, R., \& Zechner, J. (2010). Human capital, bankruptcy, and capital structure. The Journal of Finance, 65(3), 891-926.

Bhaird, C., \& Lucey, B. (2006). What determines the capital structure of SMEs: Irish evidence. Unpublished Working Paper

Black, S. E., \& Lynch, L. M. (2004). What's driving the new economy?: The benefits of workplace innovation. The Economic Journal, 114(493), F97-F116.

Block, J. H., \& Wagner, M. (2010). Necessity and opportunity entrepreneurs in germany: Characteristics and earnings differentials. Schmalenbach Business Review (Sbr), 62(2), 154-174.

Block, Z., \& MacMillan, I. C. (1985). Milestones for successful venture planning. Harvard Business Review, 63(5), 184-196.

Blundell, R., \& MaCurdy, T. (1999). Labor supply: A review of alternative approaches. Handbook of Labor Economics, 3, 1559-1695.

Booz, A. Hamilton. 1985. diversification: A survey of european chief executives. booz, allen and hamilton. Inc., New York,

Brav, O. (2009). Access to capital, capital structure, and the funding of the firm. The Journal of Finance, 64(1), 263-308.

Brüderl, J., Preisendörfer, P., \& Ziegler, R. (1992). Survival chances of newly founded business organizations. American Sociological Review, 227-242. 
Bullard, J., \& Duffy, J. (1994). Using genetic algorithms to model the evolution of heterogeneous beliefs. Working Paper Series

Bunch, D. S., \& Smiley, R. (1992). Who deters entry? evidence on the use of strategic entry deterrents. The Review of Economics and Statistics,509-521.

Cabral, L. M. B., \& Mata, J. (2003). On the evolution of the firm size distribution: Facts and theory. The American Economic Review, 93(4), pp. 1075-1090.

Carter, J. R. (1977). In search of synergy: A structure-performance test. The Review of Economics and Statistics, 59(3), 279-289.

Cassar, G., \& Craig, J. (2009). An investigation of hindsight bias in nascent venture activity. Journal of Business Venturing, 24(2), 149-164.

Casson, M. (1982). The entrepreneur: An economic theory Rowman \& Littlefield Pub Incorporated.

Casson, M. (2005). Entrepreneurship and the theory of the firm. Journal of Economic Behavior \& Organization, 58(2), 327-348.

Caves, R. E. (1980). Industrial organization, corporate strategy and structure. Journal of Economic Literature, 18(1), 64-92.

Cefis, E., \& Marsili, O. (2005). A matter of life and death: Innovation and firm survival. Industrial and Corporate Change, 14(6), 1167-1192.

Chandler, A. D. (1962). Strategy and structure: Chapters in the history of the industrial enterprise.

Chapple, K., Markusen, A., Schrock, G., Yamamoto, D., \& Yu, P. (2004). Gauging metropolitan "High-tech" and "I-tech" activity. Economic Development Quarterly, 18(1), 10-29.

Chatterjee, S. (1986). Types of synergy and economic value: The impact of acquisitions on merging and rival firms. Strategic Management Journal, 7(2), 119-139.

Chiao, C. (2002). Relationship between debt, R\&D and physical investment, evidence from US firm-level data. Applied Financial Economics, 12(2), 105-121.

Christensen, C. M. (1997). The innovator's dilemma: When new technologies cause great firms to fail Harvard Business Press.

Cohen, W. M., \& Klepper, S. (1996). A reprise of size and R \& D. The Economic Journal, 106(437), 925-951. 
Cohen, W. M., \& Levin, R. C. (1989). Empirical studies of innovation and market structure. Handbook of Industrial Organization, 2, 1059-1107.

Cooley, T. F., \& Quadrini, V. (2001). Financial markets and firm dynamics. The American Economic Review, 91(5), pp. 1286-1310.

Cox, D. R. (1972). Regression models and life-tables. Journal of the Royal Statistical Society.Series B (Methodological), 187-220.

Czarnitzki, D., \& Kraft, K. (2009). Capital control, debt financing and innovative activity. Journal of Economic Behavior \& Organization, 71(2), 372-383.

Davidsson, P., Delmar, F., \& Wiklund, J. (2006). Entrepreneurship and the growth of firms Edward Elgar Pub.

Dawid, H. (1999). Adaptive learning by genetic algorithms: Analytical results and applications to economic models Springer Verlag.

DeGroot, M. H. (2004). Optimal statistical decisions Wiley-IEEE.

Delmar, F. (2006). Measuring growth: Methodological considerations and empirical results. Entrepreneurship and the Growth of Firms, , 62-86.

DesRoches, D., Robb, A., \& Mulcahy, T. M. (2008). Kauffman Firm Survey (KFS)Baseline/First/Second Follow-Ups: Study Metadata Documentation,

Diambeidou, M. B., François, D., Gailly, B., Verleysen, M., \& Wertz, V. (2007). An empirical taxonomy of start-up firms growth trajectories. The $O E C D$ Entrepreneurship Indicators Programme: Workshop on the Measurement of HighGrowth Enterprises,

Dobbs, M., \& Hamilton, R. (2007). Small business growth: Recent evidence and new directions. International Journal of Entrepreneurial Behaviour \& Research, 13(5), 296-322.

Døving, E., \& Gooderham, P. N. (2008). Dynamic capabilities as antecedents of the scope of related diversification: The case of small firm accountancy practices. Strategic Management Journal, 29(8), 841-857.

Dunne, P., \& Hughes, A. (1994). Age, size, growth and survival: UK companies in the 1980s. The Journal of Industrial Economics, , 115-140.

Dunne, T., Roberts, M. J., \& Samuelson, L. (1989). The growth and failure of U. S. manufacturing plants. The Quarterly Journal of Economics, 104(4), pp. 671-698. 
Easley, D., \& Kiefer, N. M. (1988). Controlling a stochastic process with unknown parameters. Econometrica: Journal of the Econometric Society, 1045-1064.

El Ghoul, S., Guedhami, O., Kwok, C. C. Y., \& Mishra, D. R. (2010). Does corporate social responsibility affect the cost of capital?

Fotopoulos, G., \& Louri, H. (2000). Location and survival of new entry. Small Business Economics, 14(4), 311-321.

Galbraith, J. K. (1952). American capitalism. the concept of countervailing power, Boston: Houghton Mifflin.

Garnsey, E., Stam, E., \& Heffernan, P. (2006). New firm growth: Exploring processes and paths. Industry and Innovation, 13(1), 1.

Geroski, P. A. (1995). What do we know about entry? International Journal of Industrial Organization, 13(4), 421-440.

Geroski, P. A., Mata, J., \& Portugal, P. (2010). Founding conditions and the survival of new firms. Strategic Management Journal, 31(5), 510-529.

Geroski, P. A., Mata, J., \& Portugal, P. (2007). Founding conditions and the survival of new firmsDRUID, Copenhagen Business School, Department of Industrial Economics and Strategy/Aalborg University, Department of Business Studies.

Giarratana, M. S. (2004). The birth of a new industry: Entry by start-ups and the drivers of firm growth: The case of encryption software. Research Policy, 33(5), 787-806.

Gort, M. (1962). Diversification and integration in american industry Princeton University Press.

Hannan, M. T., \& Carroll, G. (1992). Dynamics of organizational populations: Density, legitimation, and competition Oxford University Press, USA.

Heaton, J., \& Lucas, D. (2001). Capital structure, hurdle rates, and portfolio choice interactions in an entrepreneurial firm. Unpublished Working Paper.Northwestern University, Evanston,

Heckler, D. E. (2005). High-technology employment: A NAICS-based update. Monthly Labor Review, 128(7), 57-72.

Hill, C. W. L. (1985). Diversified growth and competition: The experience of twelve large UK firms. Applied Economics, 17(5), 827-847. 
Himmelberg, C. P., \& Petersen, B. C. (1994). R \& D and internal finance: A panel study of small firms in high-tech industries. The Review of Economics and Statistics, 76(1), 38-51.

Holmstrom, B. (1989). Agency costs and innovation. Journal of Economic Behavior \& Organization, 12(3), 305-327.

Huynh, K. P., \& Petrunia, R. J. (2010). Age effects, leverage and firm growth. Journal of Economic Dynamics and Control, 34(5), 1003-1013.

Huynh, K. P., Petrunia, R. J., \& Voia, M. C. (2008). Startup financial conditions and survival of new firms.

Irwin, D. A., \& Klenow, P. J. (1994). Learning-by-doing spillovers in the semiconductor industry. Journal of Political Economy, 1200-1227.

Jovanovic, B., \& Gilbert, R. J. (1993). The diversification of production. Brookings Papers on Economic Activity.Microeconomics, 1993(1), pp. 197-247.

Kennickell, A. B. (1997). Multiple imputation and disclosure protection: The case of the 1995 survey of consumer finances. Record Linkage Techniques, 248-267.

Kim, D. J., \& Kogut, B. (1996). Technological platforms and diversification. Organization Science, , 283-301.

Klenow, P. J. (1998). Learning curves and the cyclical behavior of manufacturing industries. Review of Economic Dynamics, 1(2), 531-550.

Klepper, S. (2002). Firm survival and the evolution of oligopoly. RAND Journal of Economics, , 37-61.

Knaup, A. E., \& Piazza, M. C. (2007). Business employment dynamics data: Survival and longevity, II. Monthly Lab.Rev. 130, 3.

Korunka, C., Kessler, A., Frank, H., \& Lueger, M. (2011). Conditions for growth in oneperson startups: A longitudinal study spanning eight years. Psicothema, 23(3), 446452.

Koski, H., Marengo, L., \& Mäkinen, I. (2009). Firm size, managerial practices and innovativeness: Some evidence from finnish manufacturing. LEM Papers Series

Laursen, K., \& Foss, N. J. (2003). New human resource management practices, complementarities and the impact on innovation performance. Cambridge Journal of Economics, 27(2), 243. 
Lazear, E. P., \& Oyer, P. (2007). Personnel economics. SSRN eLibrary,

Lemieux, T., MacLeod, W. B., \& Parent, D. (2009). Performance pay and wage inequality-super-. The Quarterly Journal of Economics, 124(1), 1-49.

Levinthal, D. A. (1993). Learning and schumpeterian dynamics Wharton School, Snider Entrepreneurial Center.

Lynn, M. L. (1998). Patterns of micro-enterprise diversification in transitional eurasian economies. International Small Business Journal, 16(2), 34-49.

Lynn, M. L., \& Reinsch, N. L. J. (1990). Diversification patterns among small businesses. Journal of Small Business Management, 28(4), 60-70.

Mac An Bhaird, C., \& Lucey, B. (2006). What determines the capital structure of SMEs: Irish evidence. Working Paper, Dublin City University and Trinity College Dublin,

Mahoney, J. T., \& Pandian, J. R. (1992). The resource-based view within the conversation of strategic management. Strategic Management Journal, 13(5), 363380 .

Marcet, A., \& Nicolini, J. (2003). Recurrent hyperinflations and learning. American Economic Review, 93(5), 1476-1498.

Mata, J., \& Portugal, P. (1994). Life duration of new firms. The Journal of Industrial Economics, 42(3), 227-245.

Mata, J., \& Portugal, P. (2002). The survival of new domestic and foreign-owned firms. Strategic Management Journal, 23(4), 323-343.

Mata, J., Portugal, P., \& Guimaraes, P. (1995). The survival of new plants: Start-up conditions and post-entry evolution. International Journal of Industrial Organization, 13(4), 459-481.

Milani, F. (2007). Expectations, learning and macroeconomic persistence. Journal of Monetary Economics, 54(7), 2065-2082.

Minniti, M., \& Bygrave, W. (2001). A dynamic model of entrepreneurial learning. Entrepreneurship: Theory and Practice, 25(3)

Montgomery, C. A. (1994). Corporate diversification. The Journal of Economic Perspectives, 8(3), 163-178. 
Palich, L. E., Cardinal, L. B., \& Miller, C. C. (2000). Curvilinearity in the diversificationperformance linkage: An examination of over three decades of research. Strategic Management Journal,21(2), 155-174.

Parker, S. C. (2006). Learning about the unknown: How fast do entrepreneurs adjust their beliefs? Journal of Business Venturing, 21(1), 1-26.

Penrose, E. T., Pitelis, C. N., \& MyiLibrary. (1995). The theory of the growth of the firm Oxford University Press Oxford.

Petersen, M. A., \& Rajan, R. G. (1994). The benefits of lending relationships: Evidence from small business data. The Journal of Finance, 49(1), pp. 3-37.

Petkova, A. P. (2009). A theory of entrepreneurial learning from performance errors. International Entrepreneurship and Management Journal, 5(4), 345-367.

Petrunia, R. (2008). Does Gibrat's law hold? evidence from canadian retail and manufacturing firms. Small Business Economics, 30(2), 201-214.

Politis, D. (2005). The process of entrepreneurial learning: A conceptual framework. Entrepreneurship Theory and Practice, 29(4), 399-424.

Porter, M. E. (1998). The competitive advantage of nations: With a new introduction Free Pr.

Ramanujam, V., \& Varadarajan, P. (1989). Research on corporate diversification: A synthesis. Strategic Management Journal, 10(6), 523-551.

Renski, H. (2012). Entrepreneurial human capital, industry clusters, and new firm survival investigating the sources of localization in the study of start-up business survival. Working Papers, Paper Prepared for Presentation and Discussion at the Kauffman Firm Survey Research Conference July 2012,

Robb, A., Ballou, J., DesRoches, D., Potter, F., Zhao, Z., \& Reedy, E. (2009). An overview of the kauffman firm Survey-Results from the 2004-2007 data. Kauffman Foundation,

Robb, A., Reedy, E. J., Ballou, J., DesRoches, D., Potter, F., \& Zhao, Z. (2010). An overview of the kauffman firm survey: Results from the 2004-2008. SSRN eLibrary,

Robb, A., \& Robinson, D. T. (2008). The capital structure decisions of new firms: Second in a series of reports using data from the kauffman firm survey. SSRN eLibrary, 
Romanelli, E. (1989). Environments and strategies of organization start-up: Effects on early survival. Administrative Science Quarterly, , 369-387.

Roper, S., \& Hart, M. (2005). Small firm growth and public policy in the UK: What exactly are the connections? RP0504, Aston Business School, University of Aston, Birmingham,

Rumelt, R. P. (1974). Strategy, structure, and economic performance Division of Research, Graduate School of Business Administration, Harvard University.

Rumelt, R. P. (1982). Diversification strategy and profitability. Strategic Management Journal, 3(4), 359-369.

Sandvig, J. C. (2000). The role of technology in small firm diversification. The Journal of Technology Transfer, 25(2), 157-168.

Singh, M., \& Faircloth, S. (2005). The impact of corporate debt on long term investment and firm performance. Applied Economics, 37(8), 875-883.

Smith, K. G., Collins, C. J., \& Clark, K. D. (2005). Existing knowledge, knowledge creation capability, and the rate of new product introduction in high-technology firms. Academy of Management Journal,

Smith, S. W. (2010). Beg, borrow, and deal? entrepreneurship and financing in new firm innovation. SSRN eLibrary, (SSRN)

Teece, D. J. (1998). Capturing value from knowledge assets. California Management Review, 40(3)

Therrien, P. (2003). Empowering employees: A route to innovation Statistics Canada; Canada. Human Resources Development Canada.

Thompson, P. (2005). Selection and firm survival: Evidence from the shipbuilding industry, 1825-1914. Review of Economics and Statistics, 87(1), 26-36.

Thompson, P. (2011). Necessity and opportunity entrepreneurs through the business cycle. Working Papers, Florida International University

Trajtenberg, M. (1990). A penny for your quotes: Patent citations and the value of innovations. The Rand Journal of Economics, 21(1), pp. 172-187.

Van Praag, C. M., \& Versloot, P. H. (2007). What is the value of entrepreneurship? A review of recent research. Small Business Economics, 29(4), 351-382. 
Verwijmeren, P., \& Derwall, J. (2010). Employee well-being, firm leverage, and bankruptcy risk. Journal of Banking \& Finance, 34(5), 956-964.

Wernerfelt, B. (1984). A resource-based view of the firm. Strategic Management Journal, 5(2), 171-180.

Worldwide, W. W. (2002). Human capital index ${ }^{\circledR}$ : Human capital as a lead indicator of shareholder value. Washington, $D C$,

Yelle, L. E. (1979). The learning curve: Historical review and comprehensive survey. Decision Sciences, 10(2), 302-328.

Zoghi, C., Mohr, R. D., \& Meyer, P. B. (2010). Workplace organization and innovation. Canadian Journal of Economics/Revue Canadienne d'Économique, 43(2), 622-639. 


\section{APPENDICES}

\section{Appendix 1}

1. Methods of starting business:

(a) How was the business started

i. A new business, branch or subsidiary owned by an existing business

ii. A business inherited from someone else

iii. A new, independent business created by a single person or a team of people

iv. The purchase of an existing business

v. The purchase of a franchise

vi. An organization designed for social and charitable objectives and legally established as a ?not-for-profit

vii. Or, the business started some other way

(b) Did you pay FICA

(c) What is the legal status of business

(d) Verify the NAICS Code

2. What is the main reason the (name of original business) is out of business: Five ways of going out of business were identified
(a) Sold to Another Business Start-up
(b) Merged with Another Business
(c) Temporarily Stopped Operations
(d) Permanently Out of Business
(e) Other

3. Owner Characteristics:

(a) How many individuals or entities owned the business? Please include all individuals or entities who owned shares in the business.

(b) Of the total number of owners as of December 31, how many owners actively helped to run the business?

4. Ten dollar value categories are used in KFS for recording firms' revenue, profit, asset and total wages to avoid revealing KFS firms' sensitive financial information.
(a) $\$ 0$
(b) $\$ 500$ or less
(c) $\$ 501$ to $\$ 1,000$
(d) $\$ 1,001$ to $\$ 3,000$
(e) $\$ 3,001$ to $\$ 5,000$
(f) $\$ 5,001$ to $\$ 10,000$
(g) $\$ 10,001$ to $\$ 25,000$
(h) $\$ 25,001$ to $\$ 100,000$
(i) $\$ 100,001$ to $\$ 1$ million
(j) $\$ 1,000,001$ or more 
5. Total Intellectual Property Variables:

(a) These variables create a total number of patents, copyrights, or trademarks the businesses possessed at the time of each interview. For each type of intellectual property, the variables were constructed using data from the following questions:

(b) "Indicator" questions, such as Question D3a ("Does the business have any patents?")

(c) "Exact value" measures, such as Question D3b ("How many patents does the business have?")

6. Number of Employees:

(a) Total Number of Employees: Not Counting owner(s), on December 31, how many people worked for (name of original business).

i. Please Include all full- and part-time employees, but exclude workers who work for the business either full- or part-time but are not on the business' official payroll.

(b) Full Time Employees: ...And of those (number reported from 6a), how many were full time?

(c) Part Time Employees: ...And of those (number reported from 6a), how many were part time?

7. Number of Employees responsible for research and development:

(a) On December 31, how many employees, if any, did (name business) have who are primarily responsible for Research and Development on mew products or services? Please include only full- and part-time employees, but exclude workers who work for the business either full- or part-time but are not on the business' official payroll.

8. Business Organization and HR Benefits:

(a) As of December 31, did (name business) offer

i. a bonus plan for full-time employees/part-time employees

ii. alternative work schedules for full-time employees/part-time employees

iii. health insurance plan for full-time employees/part-time employees

iv. other benefits for full-time employees/part-time employees

v. paid sick days for full-time employees/part-time employees

vi. paid vacation for full-time employees/part-time employees

vii. a retirement plan full-time employees/part-time employees

viii. stock options for full-time employees/part-time employees

ix. tuition reimbursement for full-time employees/part-time employees

9. To identify the main owner: 
(a) Hours: During the time (name business) was in business during the year, how many hours in an average week did owner spend working at (name business)? (Specify ranges)

(b) Work Experience: How many years of work experience have you had in this industry - the one in which (name business) competes?

(c) Education: What is the highest level of education you have completed so far?

(d) Equity Percentage: What is the percentage owned by owner 1 to 14 ?

(e) How old will you be on your next birthday? (Specify ranges) 
VITA

INDU KHURANA

January 15, 1981

2009

2007

2003

2010
Born, New Delhi, India

Masters of Arts, Economics

Florida International University

Miami, Florida

Masters in Philosophy, Commerce

Delhi School of Economics

University of Delhi

New Delhi, India

Master of Commerce

Delhi School of Economics

University of Delhi

New Delhi, India

Doctoral Candidate in Economics

Florida International University

Miami, Florida 